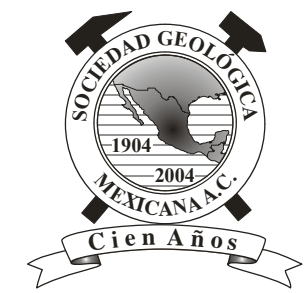

\title{
Control temporal y geología del magmatismo Permo-Triásico en Sierra Los Tanques, NW Sonora, México: Evidencia del inicio del arco magmático cordillerano en el SW de Laurencia
}

\author{
Harim E. Arvizu ${ }^{1, *}$, Alexander Iriondo ${ }^{1}$ \\ ${ }^{1}$ Centro de Geociencias, Universidad Nacional Autónoma de México, Campus Juriquilla, Querétaro, Qro., 76230, México. \\ *harimarvizu@hotmail.com
}

\begin{abstract}
Resumen
Sierra Los Tanques se localiza en el NW del Estado de Sonora, México y representa uno de los principales afloramientos de rocas graníticas permo-triásicas reportados en esa región. Geocronología U-Pb en zircón realizada en dos grupos de granitoides, los cuales afloran en el área de estudio y en diversas localidades del NW de Sonora, proporcionan un rango de edades entre $284-221$ Ma. Las variedades litológicas predominantes son las granodioritas, seguido por las cuarzomonzodioritas y monzogranitos. Se pueden diferenciar dos suites principales: granitoides melanocráticos y leucocráticos. La relación de campo existente entre los dos tipos es que los melanocráticos son más antiguos ya que son intrusionados por los leucocráticos. Esta característica es corroborada, en la mayoría de los casos, por las edades $\mathrm{U}-\mathrm{Pb}$ en zircón obtenidas de las muestras de ambas suites.

La mayoría de los zircones de los granitoides permo-triásicos indican altas concentraciones de $\mathrm{U}$ ( $\sim 47-9508 \mathrm{ppm})$, pudiéndose así explicar las pérdidas de $\mathrm{Pb}$ apreciadas en muchos de los zircones analizados. Los zircones permo-triásicos muestran relaciones $\mathrm{Th} / \mathrm{U}$ altamente variables $(0.01-0.73)$. La morfología prismática típica, además de las zonaciones oscilatorias de crecimientos magmáticos observadas en las imágenes de catodoluminiscencia, sugieren un carácter ígneo para estos zircones. La presencia de edades proterozoicas, que corresponden a núcleos heredados como se muestra en las imágenes de catodoluminiscencia, se asocia al basamento meta-ígneo de $\sim 1.7-1.6 \mathrm{Ga}, \sim 1.4 \mathrm{Ga}$ y $\sim 1.1$ Ga presente en la región, confirmado por las edades proterozoicas obtenidas de rocas de basamento para la zona de estudio.

Estos granitoides permo-triásicos asociados a subducción representan evidencia del inicio del magmatismo cordillerano en el SW de Laurencia instaurado a lo largo del borde oeste de Pangea, inmediatamente después de culminar la colisión entre Gondwana y Laurencia. Este magmatismo es importante para entender la evolución tectónica del NW de México, ya que regionalmente su ocurrencia se asocia tentativamente a una zona de debilidad cortical relacionada al basamento paleoproterozoico del Yavapai mexicano en el NW de Sonora. El entendimiento de este pulso magmático también es de particular importancia ya que representa una fuente regional de zircones detríticos permo-triásicos no reconocida anteriormente para cuencas sedimentarias mesozoicas y cenozoicas en Sonora y sur de Arizona.

Este pulso magmático, relacionado a los estadios iniciales de la subducción que propició el establecimiento de un arco magmático continental en el SW de Norteamérica, es parte de un gran evento a nivel cordillerano que se extiende desde el oeste-suroeste de Estados Unidos pasando por Sonora, Chihuahua y Coahuila a través del centro y sur de México y hasta el norte de Sudamérica.
\end{abstract}

Palabras clave: Sierra Los Tanques, permo-triásico, arco magmático continental, subducción, Laurencia.

\begin{abstract}
Sierra Los Tanques is located in NW Sonora, Mexico, and represents one of the main outcrops of Permo-Triassic granitic rocks reported in the region. $\mathrm{U}-\mathrm{Pb}$ zircon geochronology conducted in two groups of granitoids from various locations in NW Sonora provide
\end{abstract}


a range of ages between 284 - 221 Ma. Rock types are dominated by granodiorite, followed by quartzmonzodiorites, and monzogranites. There are two main granitic suites-leucocratic and melanocratic granitoids. Field relationships between the two types suggests that the melanocratic granitoids are older as they are clearly intruded by the leucocratic suite. This field evidence is supported, in most cases, by the $U-P b$ zircon ages obtained in samples of both granitic suites.

Most of the zircons from these Permo-Triassic granitoids have high U concentrations $(\sim 7-9508$ ppm), suggesting significant $\mathrm{Pb}$ loss in their crystal structure. The Permo-Triassic zircons show highly variable Th/U ratios (0.01 - 0.73). These zircons have an igneous origin not only because of their prismatic morphologies, but also due to their oscillatory zoning characteristic of magmatic growth as observed in cathodoluminescence studies. The presence of inherited cores, as shown in cathodoluminescence images, can be associated with the ages of meta-igneous Proterozoic basement present in Sierra Los Tanques ( 1.7 - 1.6 Ga, 1.4 Ga and 1.1 Ga) that could have been incorporated during magma-genesis in Permo-Triassic time.

These granitoids associated with subduction give evidence for the beginning of cordilleran arc magmatism in SW North America (Laurentia) established along the western margin of Pangea immediately following the latest stages of the collision between Laurentia and Gondwana. This Permo-Triassic magmatism is important for understanding the tectonic evolution of NW Mexico. Tentatively, the occurrence of this magmatism is associated with a zone of crustal weakness spatially associated with the Mexican Yavapai basement province in NW Sonora. Understanding this magmatic pulse is also of particular importance as it represents a regional source of detrital Permo-Triassic zircons previously unrecognized for Mesozoic and Cenozoic sedimentary basins in Sonora and southern Arizona.

Lastly, this Permo-Triassic subduction-related magmatic pulse present in NW Sonora is part of a larger magmatic arc event along the American Cordillera that extends from western-southwestern United States, passing through northern, central, and southern Mexico and reaching northern South America.

Keywords: Sierra Los Tanques, Permo-Triassic, continental magmatic arc, subduction, Laurentia.

\section{Introducción}

El arco magmático cordillerano del SW de Norteamérica es uno de los más conocidos e investigados, sin embargo, su inicio y evolución geodinámica regional son muy controvertidos. Hasta hace poco no se tenía conocimiento sobre el tiempo exacto del inicio de la subducción. Algunos estudios geológicos proponían que la convergencia a lo largo del margen continental pasivo del Paleozoico en el SW de los EUA se había originado durante el Permo-Triásico por la presencia de plutones graníticos con edades entre 260 - 207 Ma (e.g., Burchfiel y Davis, 1972, 1975, 1981; Kistler y Peterman, 1973; Dickinson, 1981; Burchfiel et al., 1992), la mayoría de edad triásica intrusionando al Cratón Laurenciano (e.g., Barth y Wooden, 2006 y sus referencias). Sin embargo, algunos de estos plutones, en la parte norte y centro de California y en el oeste de Nevada, se piensa que están relacionados a un magmatismo de arco de islas formado paralelamente al margen continental, el cual a la postre se acreció contra el continente durante el Mesozoico (e.g., Snow et al., 1991; Bateman, 1992; Burchfiel et al., 1992; Miller et al., 1992, 1995; Dunne y Saleeby, 1993; Schweickert y Lahren, 1993; Barth et al., 1997). Por su parte, los plutones en la parte sur de California y en el oeste de Arizona se encuentran asociados a subducción y fueron emplazados dentro de basamento proterozoico e intrusionando su cubierta meta-sedimentaria paleozoica (Barth et al., 1997; Barth y Wooden, 2006).

La extensión de este cinturón plutónico hacia México dentro de Sonora había sido inferida pero no así localizada (e.g., Stewart et al., 1986; Riggs et al., 2003), sino hasta el descubrimiento de rocas graníticas de edad pérmica en la Sierra Pinta, en el NW de Sonora (Figura 1), en un rango de edad entre $\sim 275-258 \mathrm{Ma}$ (Arvizu et al., 2009a). De acuerdo a esto, Arvizu et al. (2009a) proponen que el inicio del margen continental activo del SW de Norteamérica está representado por la ocurrencia de este magmatismo pérmico en el NW de México.

Como resultado del trabajo exploratorio regional en el NW de Sonora se han localizado nuevos afloramientos de rocas plutónicas asociadas al pulso magmático pérmico (Figura 1). Estas ocurrencias de afloramientos de rocas graníticas de edad permo-triásica, que intruyen a rocas de basamento meta-ígneo paleoproterozoico $(\sim 1.7-1.6 \mathrm{Ga}) \mathrm{de}$ la provincia Yavapai mexicana (Iriondo y Premo, 2010) que forman parte del SW de Laurencia, han permitido contribuir y avanzar en el conocimiento geológico de este pulso magmático mediante su reciente estudio de caracterización geoquímica y temporal (e.g., Arvizu et al., 2009a; ArvizuGutiérrez, 2012; Velázquez-Santelíz, 2014).

En general, las características geoquímicas del magmatismo Permo-Triásico en el NW de Sonora, detalladas en algunos trabajos recientes (e.g., Arvizu et al., 2009a; Arvizu-Gutiérrez, 2012), indican una firma geoquímica de granitoides calco-alcalinos con alto potasio y de carácter peraluminoso a metaluminoso, típica de granitoides formados en un ambiente de arco magmático, aunque revelando la existencia de una contribución significativa de la corteza continental para su formación (Arvizu e Iriondo, 2011), específicamente del basamento meta-ígneo de edad paleoproterozoica presente en el NW de Sonora (e.g., Iriondo y Premo, 2010). 


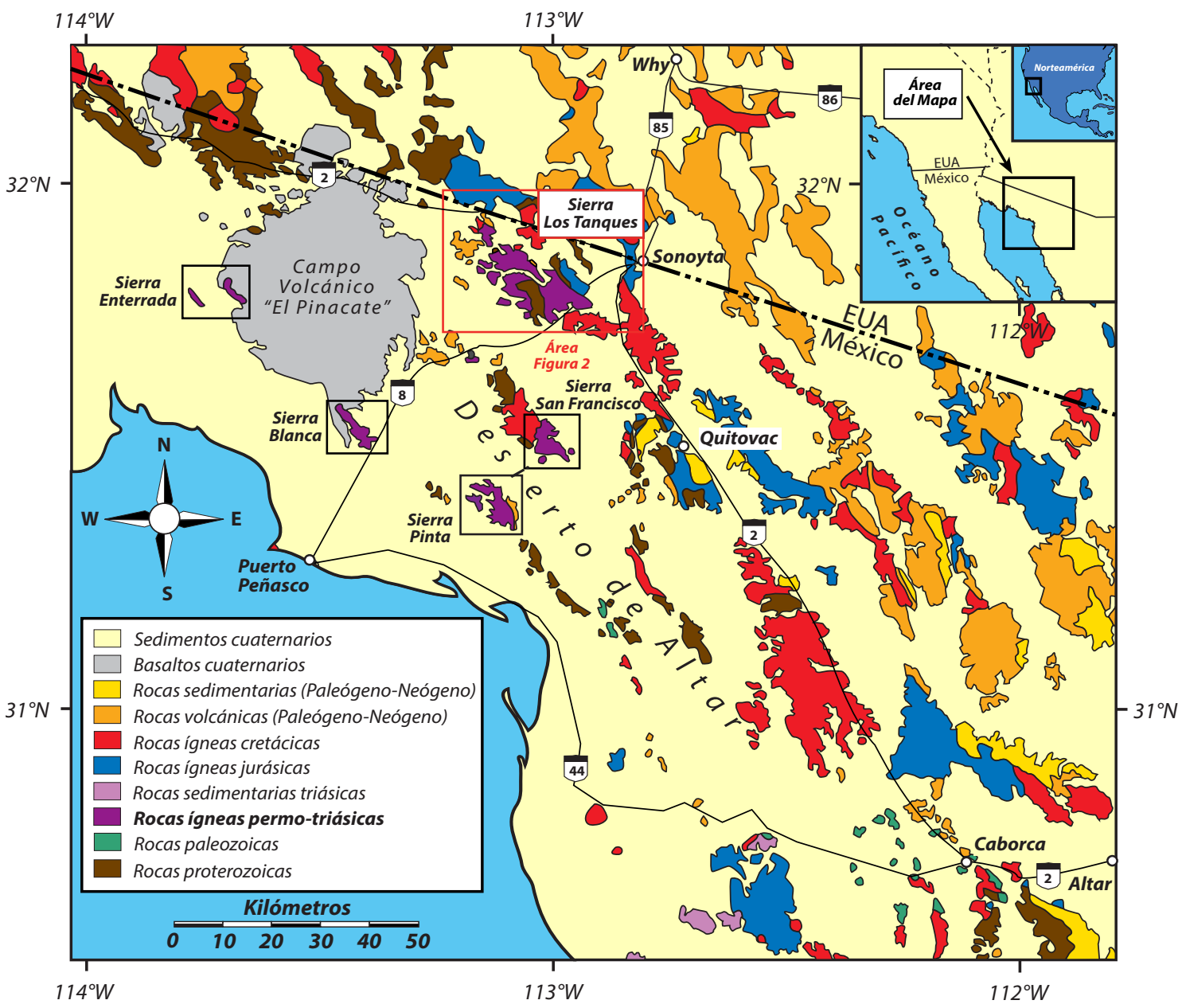

Figura 1. Mapa geológico regional del NW de Sonora y SW de Arizona modificado de Iriondo et al. (2005).

El área de estudio de la Sierra Los Tanques (Figura 1) representa geológicamente uno de los afloramientos de mayor extensión de rocas ígneas permo-triásicas encontradas hasta la fecha en el NW de México. En particular, representa una localidad interesante por la existencia de las rocas más jóvenes de este pulso magmático encontradas hasta el momento, comparadas con las localizadas en otros lugares del NW de Sonora donde únicamente se han reconocido rocas del Pérmico medio-tardío (e.g., Sierra Pinta, Sierra San Francisco, Sierra Blanca; Figura 1), permitiendo extender este pulso magmático en la región hasta el Triásico tardío ( $\sim 221 \mathrm{Ma})$ de acuerdo a los resultados obtenidos en este estudio.

En este trabajo se presentan datos geocronológicos de U-Pb en zircón, además de cartografía geológica, de granitoides permo-triásicos de la Sierra Los Tanques. Estos nuevos datos, junto a los ya existentes en la región, permitirán documentar y constreñir, por ahora, el rango de edad de este importante pulso magmático de edad permotriásica en el NW de Sonora asociado, tentativamente, al inicio de la subducción y formación del margen continental activo del SW de Norteamérica (e.g., Arvizu et al., 2009a).

\section{Geología de la Sierra Los Tanques}

\subsection{Localización}

La Sierra Los Tanques está localizada en la porción noroeste del estado de Sonora, a $\sim 15 \mathrm{~km}$ al suroeste del poblado de Sonoyta y a $\sim 100 \mathrm{~km}$ al noreste de la ciudad de Puerto Peñasco; específicamente se encuentra al este del campo volcánico El Pinacate de edad cuaternaria (Figura 1). Así mismo se encuentra ubicada dentro de la Reserva de la Biosfera El Pinacate, en la parte más oriental del Gran Desierto de Altar, justo al sur de la frontera con Arizona (Figura 2).

\subsection{Trabajos previos en el área de estudio}

Los primeros estudios de cartografía geológica en Sierra Los Tanques fueron los realizados por el Servicio Geológico Mexicano (2002) y posteriormente los llevados a cabo por Campbell y Anderson (2003). Estos últimos 


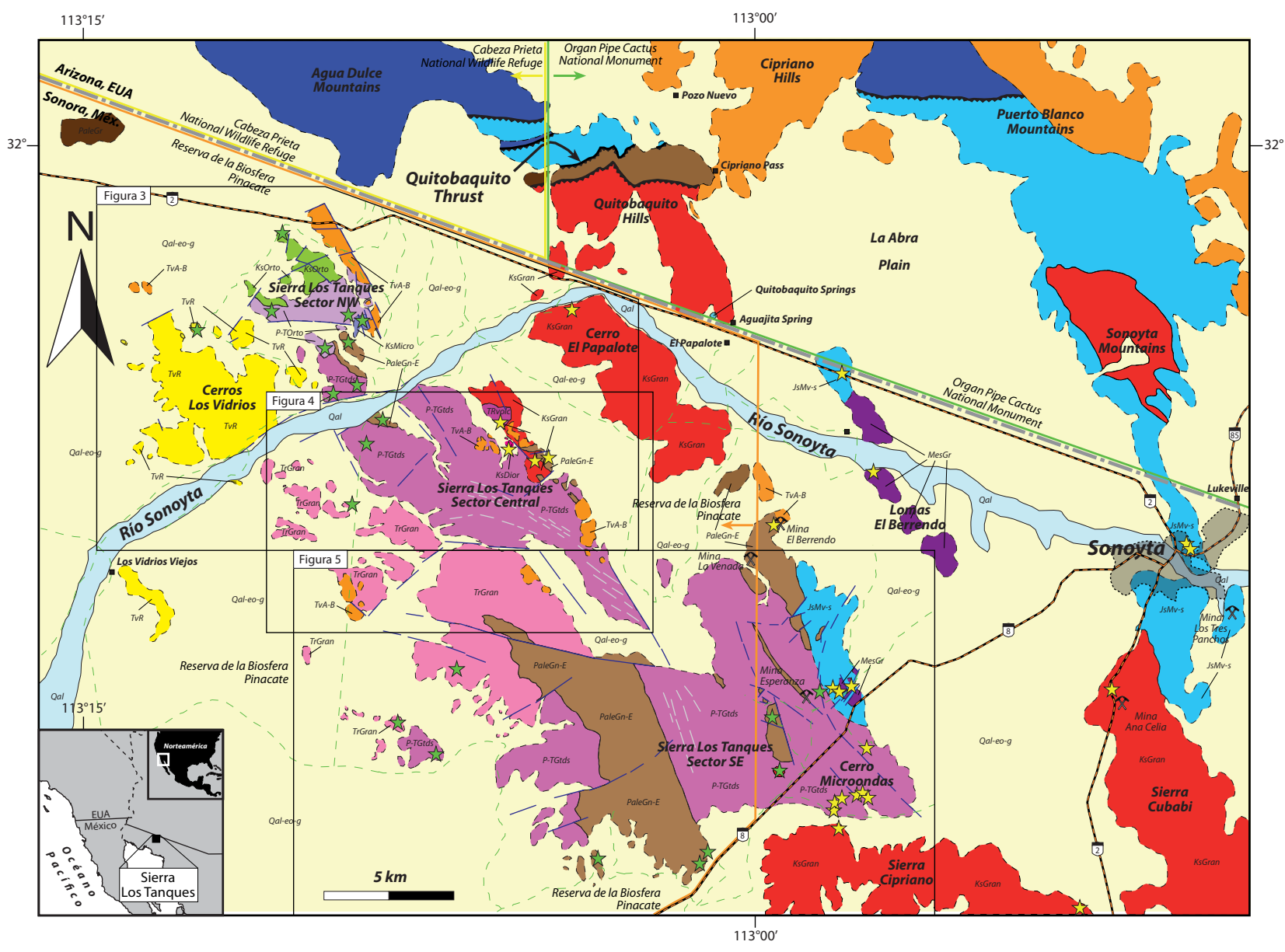

\section{Leyenda y Explicación}

\section{CENOZOICO}

\section{Cuaternario}

Qal Depósitos de aluvión de edad cuaternaria. Material detrítico transportado y depositado por el Río Sonoyta compuesto por grava, arena, arcilla y limo.

Qal-eo-g Depósitos aluviales, dunas de arena y grava de edad Mioceno al reciente.

\section{Mioceno}

$T v R$

Rocas volcánicas de composición riolítica de edad Mioceno medio (Vidal-Solano et al., 2008).

Edad U-Pb en zircones de 14.2 \pm 0.1 Ma de una riolita fechada en este estudio.

TvA-B Rocas volcánicas de composición basáltica-andesítica de edad Mioceno inferior (Vidal-Solano et al., 2008).

\section{MESOZOICO}

\section{Cretácico Superior}

Granitoides de edad laramídica ( 59-78 Ma: Arvizu-Gutiérrez, 2012; R. García-Flores, com pers, 2015). Granito de biotita

granodiorita y diorita en Sierra Los Tanques (Cerros El Papalote, Cipriano y Cubabi). Granito de biotita y de dos micas con granate en Sonoyta Mountains. Granito de biotita Aquajita Springs con edad $~ 84$ Ma (Campbell y Anderson, 2003).

KsMicro Microdiorita de edad laramídica. Edad U-Pb en zircones de $72.7 \pm 0.6 \mathrm{Ma}$ (Arvizu-Gutiérrez, 2012).

\section{Jurásico Medio-Inferior}

Rocas metavolcánicas-metasedimentarias (metariolitas, metandesitas, metareniscas, esquistos y filitas) del Jurásico medio con diferentes grados de deformación. Edades U-Pb en zircones de protolitos de 164-176 Ma (R. García-Flores, com. pers., 2015) y de 180 Ma (Campbell y Anderson, 2003). 


\section{Triásico Medio}

TRvolc Roca metavolcánica? de edad triásica (R. García-Flores, com. pers., 2015).

TrGran Granito de biotita y de dos micas de edad triásica. Edades U-Pb en zircones de 221-240 Ma en este estudio.

\section{MESOZOICO-PALEOZOICO}

\section{Permo-triásico}

P-TOrto Ortogneis milonitizado de edad permo-triásica. Edades U-Pb en zircones de 243-257 Ma en este estudio. Granitoides permo-triásicos leucocráticos y melanocráticos foliados.

P-TGtds Edades U-Pb en zircones de granitoides leucocráticos de 226-254 Ma en este estudio y de 250-267 Ma para melanocráticos (R. García-Flores, com. pers., 2015). Pegmatitas y aplitas leucocráticas con granate de edad permo-triásica (251-261 Ma; R. García-Flores, com. pers., 2015).

\section{PROTEROZOICO}

Mesoproterozoico

\section{Paleoproterozoico}

PaleGr Ortogneis de biotita intruido por un granito de biotita de grano más fino, ambos de edad paleoproterozoica.

Edades U-Pb en zircones de 1654 Ma para el ortogneis de biotita y de 1637 Ma para el granito de biotita de grano fino (Arvizu-Gutiérrez, 2012).

Gneises cuarzo-feldespáticos bandeados, esquistos, filitas y anfibolitas de edad paleoproterozoica.

Edades U-Pb en zircones de gneises bandeados de 1682-1763 Ma (Arvizu-Gutiérrez, 2012) y de 1720-1747 Ma (R. García-Flores, com. pers., 2015).
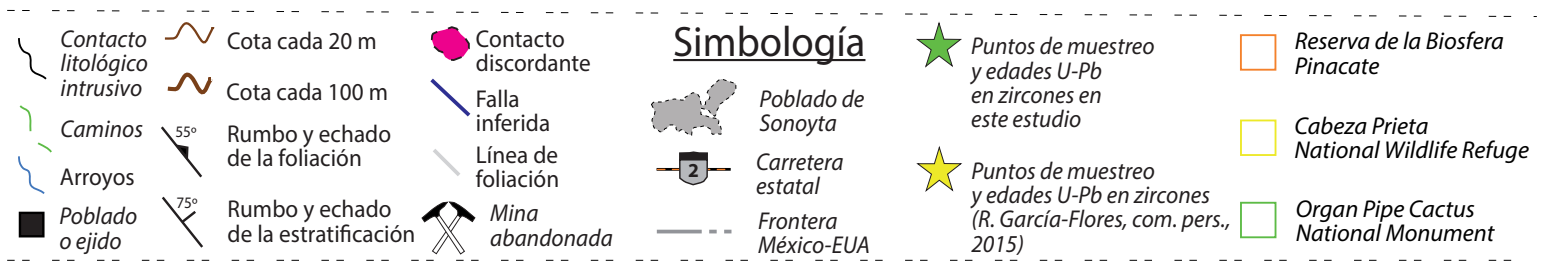

Figura 2. Mapa litológico sintetizado de Sierra Los Tanques (Sonora) a partir de la cartografía realizada en este estudio. La cartografía de Quitobaquito Hills (Arizona) y alrededores es a partir de mapas publicados por Campbell y Anderson (2003), Haxel et al. (1984) y SGM (2002).

estudios son los más detallados, los cuales demuestran la complejidad geológica de la zona de estudio que es avalada por las descripciones litológicas mostradas en las leyendas de los mapas geológicos presentados en su trabajo. El propósito de su estudio fue realizar una cartografía geológica-estructural que les permitiera describir las estructuras y cinemática presentes en las rocas mesozoicas y precámbricas milonitizadas que afloran en el área, sugiriendo que estas rocas se formaron a lo largo de una falla lateral izquierda, activa a finales del Jurásico (concepto de la hipotética Megacizalla Mojave-Sonora; Silver y Anderson, 1974; Anderson y Silver, 1979, 2005).

2.3. Descripción geológica y marco tectónico de las unidades litológicas

El área de estudio fue dividida en tres sectores principales: Sector NW, Central y SE (Figuras 2 - 5) con fines logísticos para llevar a cabo la cartografía geológica. A continuación se describen las unidades litológicas en orden cronológico.

\subsubsection{Proterozoico}

2.3.1.1. Paleoproterozoico. Las rocas paleoproterozoicas presentes en la Sierra Los Tanques (Figuras 2 - 5) se encuentran como unidades litológicas de diversas composiciones constituidas principalmente por gneises bandeados cuarzo-feldespáticos de biotita, gneises de clorita-biotita y, en menor cantidad, paragneises de biotita $\mathrm{y}$ de dos micas incluyendo algunos esquistos y filitas de clorita-biotita-epidota. En algunas ocasiones, estas rocas se encuentran con intercalaciones de anfibolitas con espesor variable.

Los afloramientos principales de esta unidad litológica se encuentran en el sector sureste de la Sierra Los Tanques, en donde se ubican los afloramientos de mayor extensión y algunas exposiciones aisladas afloran en el sector central y noroeste (Figura 2). En varias localidades, principalmente en el sector sureste, esta unidad gnéisica paleoproterozoica aflora casi siempre como remanentes en o dentro de las rocas más jóvenes (granitoides permo-triásicos) a manera de techos colgantes (roof pendants) o como grandes bloques o xenolitos (Figuras 6 A y B).

La relación que tiene esta unidad con las rocas graníticas más jóvenes presentes en el área es de tipo intrusivo ya que la mayoría de los granitoides y pegmatitas-aplitas de edad permo-triásica se encuentran cortando perpendicular y/o 


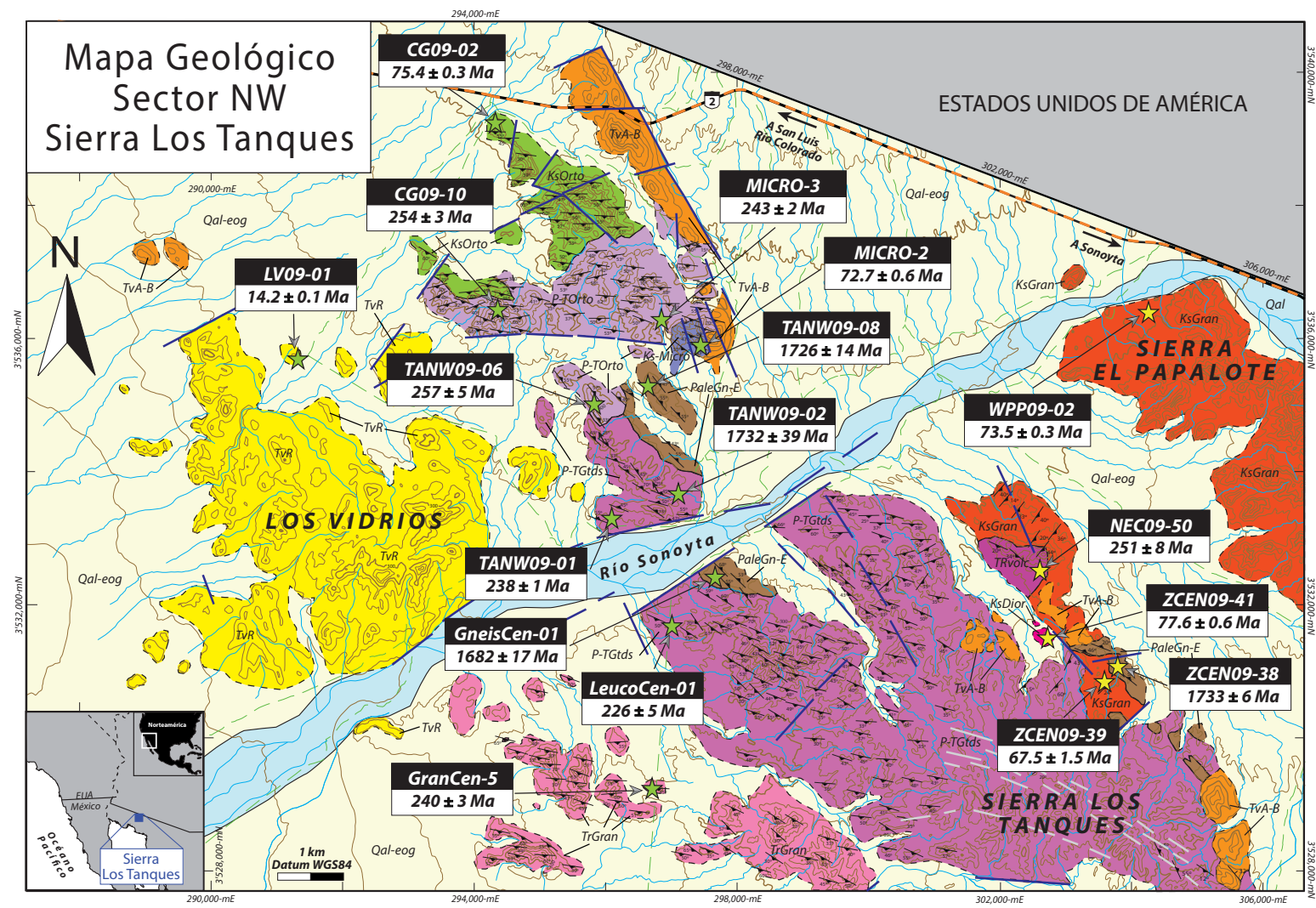

Figura 3. Mapa geológico-litológico del Sector NW de Sierra Los Tanques a partir de la cartografía realizada en este estudio. La leyenda y explicación, además de la simbología, son las mismas que la Figura 2. En este mapa se observan, con estrellas de color verde, los puntos de muestreo para los análisis geocronológicos y geoquímicos, además el nombre de la muestra y su edad U-Pb en zircones.

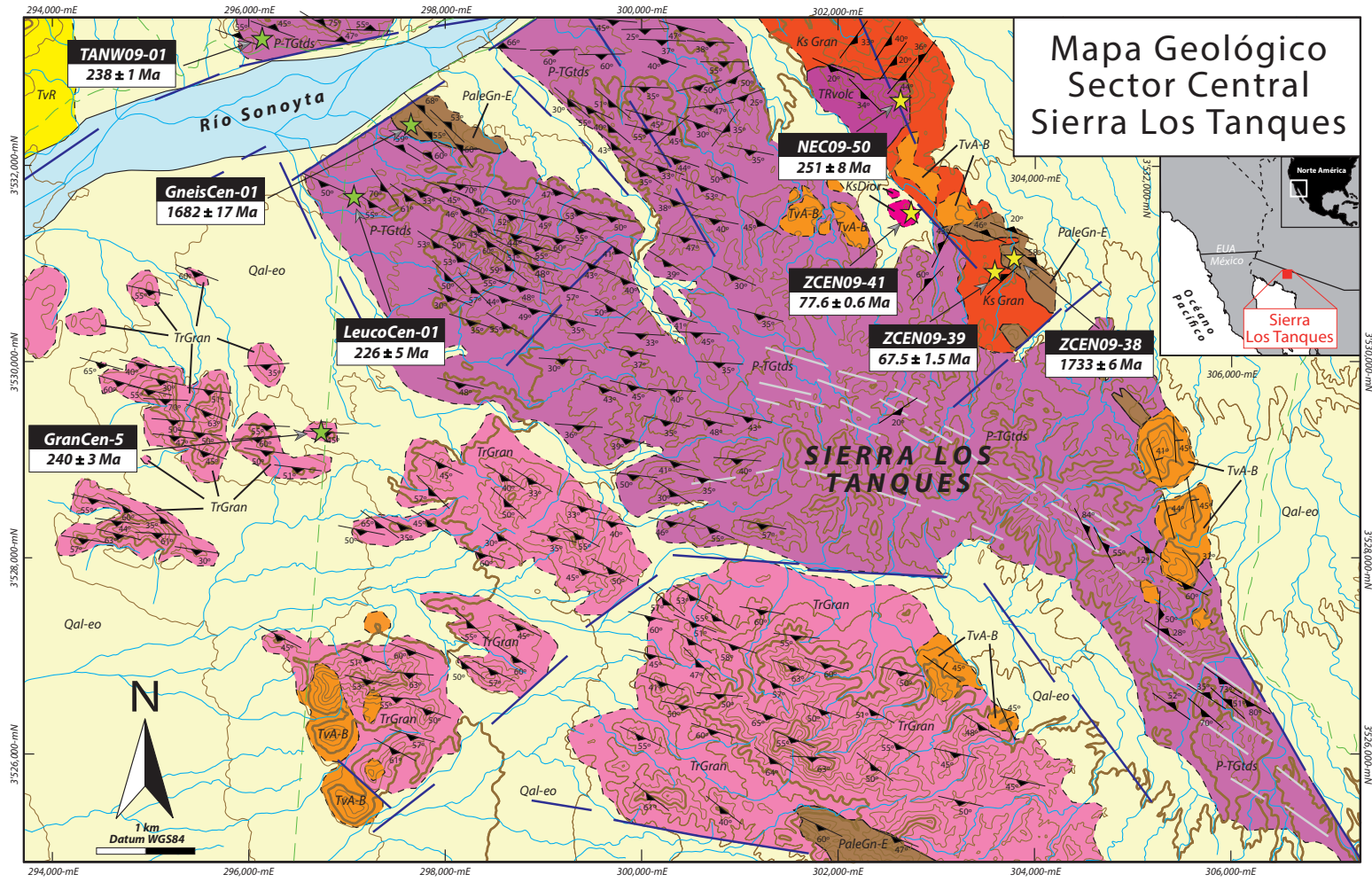

Figura 4. Mapa geológico-litológico del Sector Central de Sierra Los Tanques a partir de la cartografía realizada en este estudio. La leyenda y explicación, además de la simbología, son las mismas que la Figura 2. 


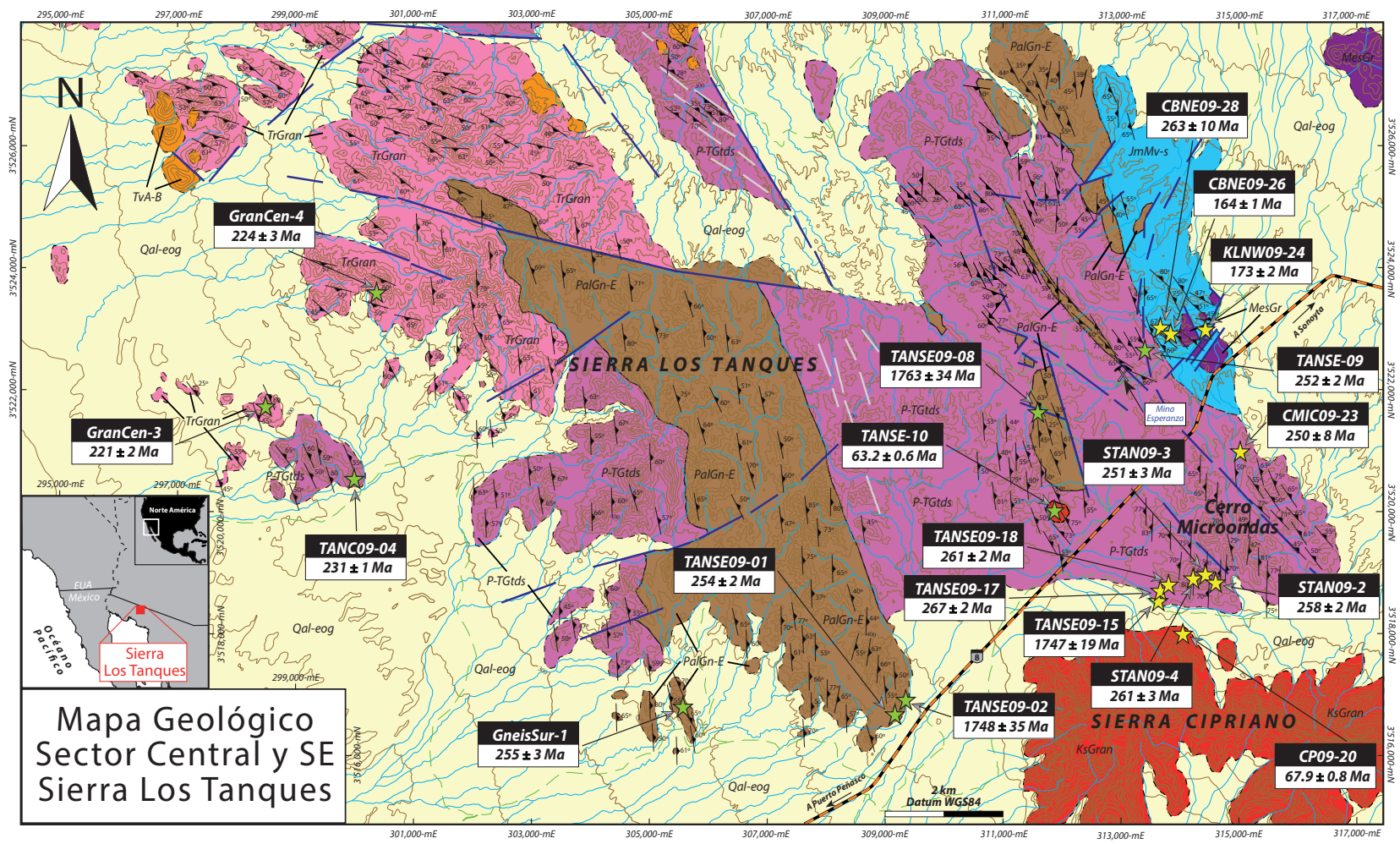

Figura 5. Mapa geológico-litológico del Sector Central y SE de Sierra Los Tanques a partir de la cartografía realizada en este estudio. La leyenda y explicación, además de la simbología, son las mismas que la Figura 2.

sub-paralelamente a la foliación del basamento precámbrico (Figura 6C). En ocasiones también se observan bandas cuarzo-feldespáticas abudinadas (Figura 6D). Aunque en algunas zonas aún se preservan las texturas ígneas de los protolitos de estas rocas gnéisicas, en algunos otros lugares muestran una foliación milonítica (Figura 6E).

La foliación, localmente, está plegada a escala centimétrica y en algunas ocasiones a escalas mayores (Figura 6F). Las foliaciones del sector noroeste (Figura 3) muestran un patrón de rumbos entre $30^{\circ}-40^{\circ} \mathrm{NW}$ con echados entre $50^{\circ}$ y $70^{\circ}$ preferentemente hacia el NE. Por otro lado, el patrón que presentan las foliaciones en el sector sureste (Figura 5) es más homogéneo en rumbos y echados. Los rumbos predominantes de las foliaciones varían entre $10^{\circ}$ y $30^{\circ} \mathrm{NW}$, algunas veces N-S y echados entre $60^{\circ}$ y $80^{\circ}$ hacia el NE, y en ocasiones llegando a ser verticales. En el sector sureste, cerca del contacto con las rocas jurásicas por discordancia, las foliaciones no son tan homogéneas variando ligeramente sus rumbos y echados en diferentes direcciones, encontrándose algunos hacia el SW y otros hacia el NE, incluso algunos hacia el NW y SE (Figura 5). Estas diferentes orientaciones son interpretadas como plegamiento de estas unidades previamente foliadas.

Edades U-Pb en zircón determinadas en gneises bandeados de varios afloramientos ubicados en diferentes sectores del área de estudio (estrellas verdes en la Figura 2) oscilan entre 1763 y $1682 \mathrm{Ma}$ (Arvizu-Gutiérrez, 2012). Este rango de edades es similar al resto de las rocas del basamento paleoproterozoico presente en Sierra Los Tanques (1747 - 1720 Ma; R. García, com. pers., 2015) y consistentes y correlacionables con rocas en otras regiones en el NW de Sonora (e.g., Iriondo et al., 2004; Nourse et al., 2005; Izaguirre et al., 2008; Arvizu et al., 2009b).

2.3.1.2. Mesoproterozoico. El magmatismo mesoproterozoico en la Sierra Los Tanques está representado por un pulso granítico de $\sim 1.1 \mathrm{Ga}$ (Iriondo et al., 2008); uno de los dos episodios de actividad magmática mesoproterozoica $(\sim 1.4 \mathrm{Ga} \mathrm{y} \sim 1.1 \mathrm{Ga})$ asociados posiblemente a rifting, que son conocidos regionalmente en el SW de Norteamérica (e.g., Anderson y Cullers, 1999; Goodge y Vervoort, 2006 y sus referencias).

El afloramiento principal de granitoides mesoproterozoicos se encuentra en Lomas El Berrendo ubicado en la porción oriental del área de estudio (Figura 2). Estos cuerpos intrusionan a rocas de basamento más antiguo de edad paleoproterozoica que tienen características y afinidad con corteza tipo Yavapai (e.g., Iriondo y Premo, 2010). Afloramientos aislados se encuentran en el sector sureste de la Sierra Los Tanques (Figura 5) en contacto discordante con las rocas metavolcánicas-metasedimentarias jurásicas (Figura 5). Un granito mesoproterozoico en la Sierra Los Tanques ha sido fechado en $1100 \pm 8 \mathrm{Ma}$; edad ${ }^{207} \mathrm{~Pb} /{ }^{206} \mathrm{~Pb}$ en zircón determinada por Iriondo et al. (2008), $\mathrm{y}$ recientemente en otras localidades en un rango entre 1083 - $1064 \mathrm{Ma}$ (estrellas amarillas en la Figura 2; R. García, 

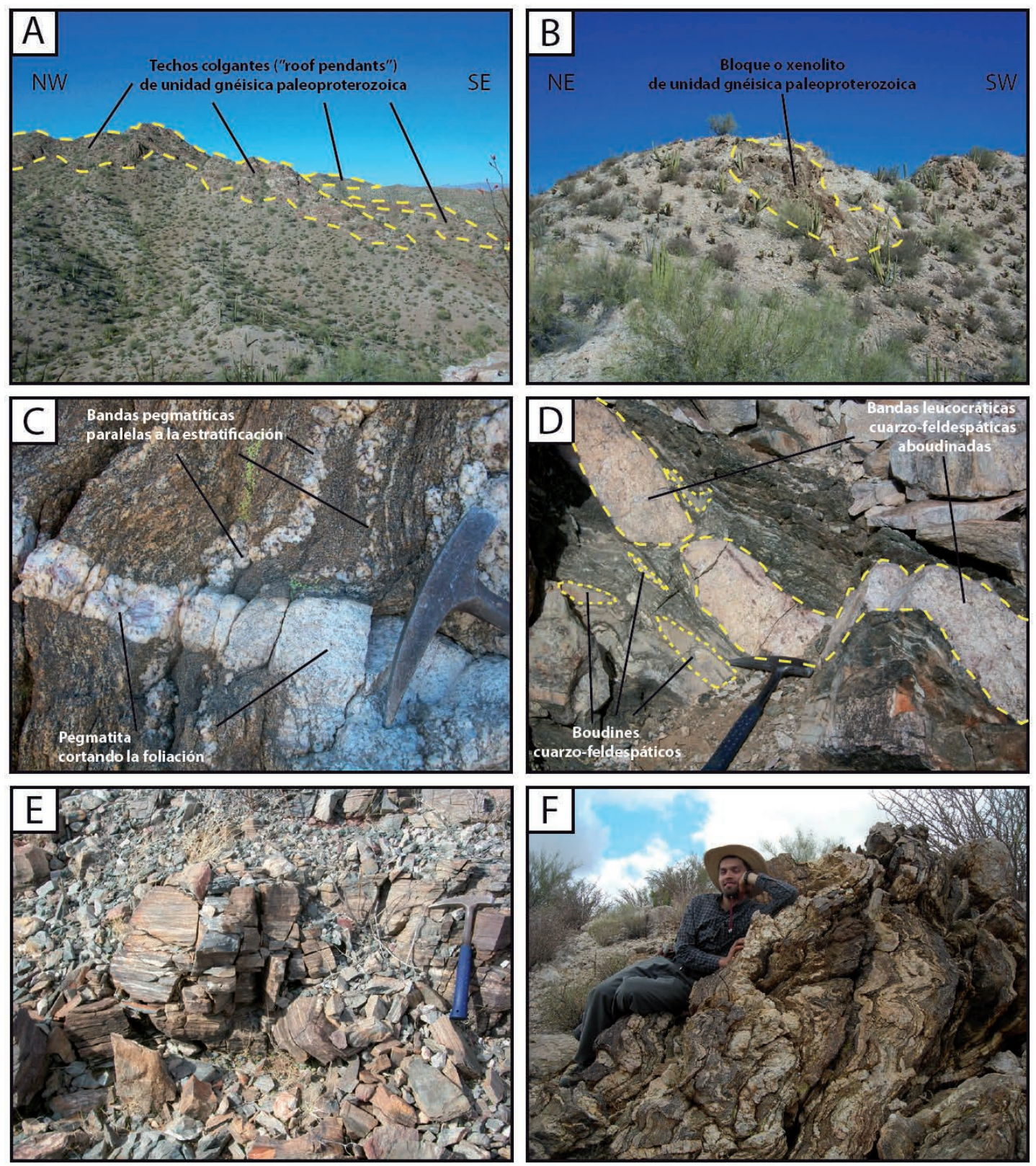

Figura 6. (A) Fotografías mostrando afloramientos representativos y relaciones de campo de la unidad gnéisica paleoproterozoica de Sierra Los Tanques. (A) y (B) Vistas panorámicas de dos afloramientos representativos ubicados en el sector central y sur, respectivamente, de Sierra Los Tanques, en donde se observa a la unidad gnéisica paleoproterozoica aflorando como remanentes sobre las rocas más jóvenes a manera de techos colgantes (roof pendants) o como grandes bloques o xenolitos dentro de las unidades graníticas permo-triásicas. (C) Segregaciones leucocráticas de diques pegmatíticos cortando a la foliación de la unidad gnéisica. También se observan bandas de la misma composición paralelas a la estratificación. (D) Bandas leucocráticas con textura pegmatítica abudinadas compuestas principalmente de cuarzo. (E) Afloramiento representativo de la unidad de gneises bandeados. Nótese que la foliación define una fábrica general gnéisica. (F) La deformación presente en esta unidad gnéisica es muy alta mostrándose en algunos sectores un fuerte plegamiento.

com. pers., 2015).

\subsubsection{Paleozoico-Mesozoico}

2.3.2.1. Permo-Triásico. La unidad litológica predominante en la Sierra Los Tanques corresponde a un conjunto de granitoides permo-triásicos (Figuras $2-5$ ). Las variedades litológicas presentes son las granodioritas y cuarzomonzodioritas, aunque también existen monzogranitos, monzodioritas, cuarzosienitas y cuarzomonzonitas (Tabla 1). Esta clasificación se detalla en el apartado de geoquímica en Arvizu-Gutiérrez (2012). Debido a la complejidad y a la gran diferenciación de los granitoides de esta unidad permo-triásica, estas rocas se pueden dividir en dos facies litológicas de acuerdo al índice de color (es decir, al contenido de minerales máficos y/o félsicos en la roca) en granitoides melanocráticos 
y leucocráticos. Petrográficamente también se pueden distinguir los dos grupos de granitoides, en general, ambos tipos de granitoides tienen texturas faneríticas a porfídicas con tamaños de grano medio a grueso, en algunas ocasiones con grandes fenocristales (Figuras 7 A y B). Algunos granitoides muestran texturas esquistosas-gnéisicas (Figuras $7 \mathrm{C} \mathrm{y} \mathrm{D)} \mathrm{debido} \mathrm{a} \mathrm{la} \mathrm{foliación} \mathrm{incipiente} \mathrm{producida} \mathrm{por}$ metamorfismo de bajo grado en facies de esquistos verdes asociado a un evento tectónico regional presente en el área de estudio de posible edad laramídica (R. García, com. pers., 2015). La plagioclasa, el cuarzo y el feldespato alcalino son las fases predominantes en la mayoría de los granitoides variando su contenido en mayor o menor proporción en cada una de las litologías presentes, aunque la plagioclasa tiende a ser la fase más dominante (Tabla 1). En menor cantidad se encuentran la hornblenda y la biotita (Figura $7 \mathrm{E}$ ), las cuales son las fases máficas dominantes en los granitoides melanocráticos. Otro de los minerales comunes pero en los granitoides leucocráticos es la moscovita, típica de granitos peraluminosos. La moscovita es muy común en los granitoides leucocráticos y ocurre como mineral ígneo primario. Como mineral secundario reemplazando casi siempre al feldespato se observa mica blanca (Figuras 7 F y G). Algunos otros minerales secundarios, como la clorita y la epidota, también están presentes en algunas rocas, principalmente la clorita reemplazando a la biotita, y la epidota reemplazando a la plagioclasa y/o feldespato, igualmente en algunas ocasiones a la hornblenda (Figuras $7 \mathrm{H} \mathrm{e} \mathrm{I}$ ). Como minerales accesorios se encuentran principalmente el zircón, el apatito, la esfena o titanita y los minerales opacos como la magnetita-ilmenita, además del granate que es una fase mineral presente únicamente en los granitoides leucocráticos (Figuras $7 \mathrm{~J}, \mathrm{~K} \mathrm{y} \mathrm{L}$ ).

El conjunto de granitoides permo-triásicos intrusionan a la unidad metamórfica paleoproterozoica de gneises bandeados cuarzo-feldespáticos. Se observan cuerpos graníticos que intrusionan sub-paralelamente a la foliación de los gneises bandeados, y en algunas ocasiones se ve cortando perpendicularmente a ésta (Figura 8A). También se aprecian pequeños bloques, a manera de enclaves, de la unidad gnéisica paleoproterozoica dentro de las masas graníticas leucocráticas (Figura 8B).

En los afloramientos de esta unidad granítica en el sector noroeste (Figura 3), las foliaciones presentan un patrón de rumbos E-W $\left(85^{\circ} \mathrm{NW}-80^{\circ} \mathrm{NE}\right)$ con echados variables entre $30^{\circ}-60^{\circ}$ con dirección preferentemente hacia el SW. En algunas zonas los granitoides muestran un diferente patrón de foliaciones con rumbos NW-SE, específicamente $20^{\circ}-45^{\circ} \mathrm{NW}$ con echados entre $30^{\circ}-70^{\circ}$ hacia el NE (Figura 3). Esta orientación de foliaciones también está presente en las rocas gnéisicas paleoproterozoicas que se encuentran dentro de esta unidad a manera de bloques o xenolitos o simplemente como basamento. Por su parte, los granitoides en el sector central (Figura 4) tienen un patrón homogéneo de foliaciones con rumbos NW-SE y echados entre $30^{\circ}-60^{\circ}$ hacia el SW, preferentemente. En el sector sureste de la Sierra Los Tanques (Figura 5) se encuentra la mayor extensión de afloramientos de granitoides permo-triásicos. En esta zona las foliaciones de las rocas tienen rumbos NW-SE con echados hacia el SW. También

Tabla 1. Localización de muestras, clasificación, arreglos minerales y edades U-Pb en zircones de granitoides permo-triásicos de Sierra Los Tanques, NW de Sonora, México.

\begin{tabular}{|c|c|c|c|c|c|c|c|c|}
\hline Muestra & Lat. $\left({ }^{\circ} \mathbf{N}\right)^{\dagger}$ & Long. $\left({ }^{\circ} \mathbf{W}\right)^{\dagger}$ & Tipo de roca & Nombre de la roca & Minerales primarios & $\begin{array}{c}\text { Minerales } \\
\text { secundarios }\end{array}$ & Minerales accesorios & Edad (Ma)* \\
\hline \multicolumn{9}{|c|}{ Sierra Los Tanques (Este estudio) } \\
\hline TANW09-06 & $31^{\circ} 55^{\prime} 59^{\prime \prime}$ & $113^{\circ} 09^{\prime} 33^{\prime \prime}$ & Granodiorita & Granodiorita de biotita & $\mathrm{Pl}+\mathrm{Kfs}+\mathrm{Qtz}+\mathrm{Bt}$ & Ep & $\operatorname{Ttn}+A p+Z r n+M i n . O p$ & $257 \pm 5 \mathrm{Ma}$ \\
\hline GneisSur-1 & $31^{\circ} 46^{\prime} 11^{\prime \prime}$ & $113^{\circ} 03^{\prime} 10^{\prime \prime}$ & Gneis & Gneis de biotita & $\mathrm{Qtz}+\mathrm{Kfs}+\mathrm{Pl}+\mathrm{Bt}$ & $\mathrm{Ms}+\mathrm{Ep}+\mathrm{Chl}$ & Ap+Zrn+ Min. Op. & $255 \pm 3 \mathrm{Ma}$ \\
\hline CG09-10 & $31^{\circ} 56^{\prime} 44^{\prime \prime}$ & $113^{\circ} 10^{\prime} 30^{\prime \prime}$ & Monzogranito & Monzogranito de biotita & $\mathrm{Pl}+\mathrm{Kfs}+\mathrm{Qtz}+\mathrm{Bt}$ & Ep & Ttn+Ap+Zrn+Min. Op. & $254 \pm 3 \mathrm{Ma}$ \\
\hline TANSE09-01 & $31^{\circ} 46^{\prime} 14^{\prime \prime}$ & $113^{\circ} 00^{\prime} 49^{\prime \prime}$ & Granodiorita (aplita) & $\begin{array}{l}\text { Granodiorita leucocrática con } \\
\text { granate y biotita }\end{array}$ & $\mathrm{Pl}+\mathrm{Qtz}+\mathrm{Kfs}+\mathrm{Bt}+\mathrm{Grt}$ & N.D. & $\mathrm{Ap}+\mathrm{Zrn}+\mathrm{Min} . \mathrm{Op}$ & $254 \pm 2 \mathrm{Ma}$ \\
\hline TANSE-09 & $31^{\circ} 49^{\prime} 33^{\prime \prime}$ & $112^{\circ} 58^{\prime} 21^{\prime \prime}$ & Granodiorita & $\begin{array}{l}\text { Granodiorita leucocrática de } \\
\text { biotita }\end{array}$ & $\mathrm{Pl}+\mathrm{Qtz}+\mathrm{Kfs}+\mathrm{Bt}$ & N.D. & Ttn+Ap+Zrn+Min. Op. & $252 \pm 3 \mathrm{Ma}$ \\
\hline GranCen-3 & $31^{\circ} 48^{\prime} 46^{\prime \prime}$ & $113^{\circ} 07^{\prime} 51^{\prime \prime}$ & Granodiorita & $\begin{array}{l}\text { Granodiorita leucocrática de } \\
\text { dos micas }\end{array}$ & $\mathrm{Pl}+\mathrm{Qtz}+\mathrm{Kfs}+\mathrm{Bt}+\mathrm{Ms}$ & N.D. & $\mathrm{Ap}+\mathrm{Zrn}+$ Min. Op. & $252 \pm 2 \mathrm{Ma}$ \\
\hline MICRO-3 & $31^{\circ} 56^{\prime} 35^{\prime \prime}$ & $113^{\circ} 08^{\prime} 52^{\prime \prime}$ & Cuarzomonzodiorita & Cuarzomonzodiorita de biotita & $\mathrm{Pl}+\mathrm{Kfs}+\mathrm{Qtz}+\mathrm{Bt}$ & Ep & $\operatorname{Ttn}+A p+Z r n+$ Min. Op. & $243 \pm 2 \mathrm{Ma}$ \\
\hline GranCen-5 & $31^{\circ} 52^{\prime} 52^{\prime \prime}$ & $113^{\circ} 08^{\prime} 58^{\prime \prime}$ & Granodiorita & $\begin{array}{l}\text { Granodiorita leucocrática de } \\
\text { biotita }\end{array}$ & $\mathrm{Pl}+\mathrm{Qtz}+\mathrm{Kfs}+\mathrm{Bt}$ & N.D. & $\mathrm{Ap}+\mathrm{Zrn}+$ Min. Op. & $240 \pm 3 \mathrm{Ma}$ \\
\hline TANW09-01 & $31^{\circ} 54^{\prime} 58^{\prime \prime}$ & $113^{\circ} 09^{\prime} 30^{\prime \prime}$ & Granodiorita & $\begin{array}{l}\text { Granodiorita leucocrática de } \\
\text { dos micas }\end{array}$ & $\mathrm{Pl}+\mathrm{Qtz}+\mathrm{Kfs}+\mathrm{Bt}+\mathrm{Ms}$ & Ms & Ap+Zrn+ Min. Op. & $238 \pm 1 \mathrm{Ma}$ \\
\hline TANC09-04 & $31^{\circ} 48^{\prime} 10^{\prime \prime}$ & $113^{\circ} 06^{\prime} 41^{\prime \prime}$ & Granodiorita & $\begin{array}{l}\text { Granodiorita leucocrática de } \\
\text { biotita }\end{array}$ & $\mathrm{Pl}+\mathrm{Qtz}+\mathrm{Kfs}+\mathrm{Bt}$ & $\mathrm{Ms}+\mathrm{Ep}$ & $\mathrm{Ap}+\mathrm{Zrn}+$ Min. Op. & $231 \pm 1 \mathrm{Ma}$ \\
\hline LeucoCen-1 & $31^{\circ} 54^{\prime} 10^{\prime \prime}$ & $113^{\circ} 08^{\prime} 47^{\prime \prime}$ & Granodiorita & Granodiorita de biotita & $\mathrm{Pl}+\mathrm{Qtz}+\mathrm{Kfs}+\mathrm{Bt}+\mathrm{Grt}$ & $\mathrm{Ms}+\mathrm{Chl}$ & $\mathrm{Ap}+\mathrm{Zrn}+$ Min. Op. & $226 \pm 5 \mathrm{Ma}$ \\
\hline GranCen-4 & $31^{\circ} 49^{\prime} 43^{\prime \prime}$ & $113^{\circ} 06^{\prime} 25^{\prime \prime}$ & Granodiorita & $\begin{array}{l}\text { Granodiorita leucocrática de } \\
\text { dos micas }\end{array}$ & $\mathrm{Pl}+\mathrm{Qtz}+\mathrm{Kfs}+\mathrm{Bt}+\mathrm{Ms}$ & Ep & $\mathrm{Ap}+\mathrm{Zrn}+\mathrm{Min} . \mathrm{Op}$ & $224 \pm 3 \mathrm{Ma}$ \\
\hline
\end{tabular}

Abreviaturas: $\mathrm{Qtz}=$ Cuarzo, $\mathrm{Kfs}=$ Feldespato potásico, $\mathrm{Pl}=$ Plagioclasa, $\mathrm{Bt}=$ Biotita, $\mathrm{Ms}=$ Moscovita, $\mathrm{Ser}=$ Sericita, Hbl = Hornblenda, Ep $=$ Epidota, $\mathrm{Chl}=$ Chlorita, $\mathrm{Ap}=$ Apatito, Grt $=$ Granate, $\mathrm{Ttn}=$ Titanita, $\mathrm{Zrn}=$ Zircón .

Min. Op. $=$ Minerales opacos, F.A. $=$ Feldespato Alcalino. N.D. $=$ No Determinado.

${ }^{\dagger}$ Lat. $=$ Latitud, Long. $=$ Longitud. DATUM WGS84.

${ }^{*} E d a d e s{ }^{206} \mathrm{~Pb} /{ }^{238} \mathrm{U}$ de zircones determinadas en este estudio por técnica de ablación laser (LA-ICPMS) reportadas a precisión $2 \sigma$. 

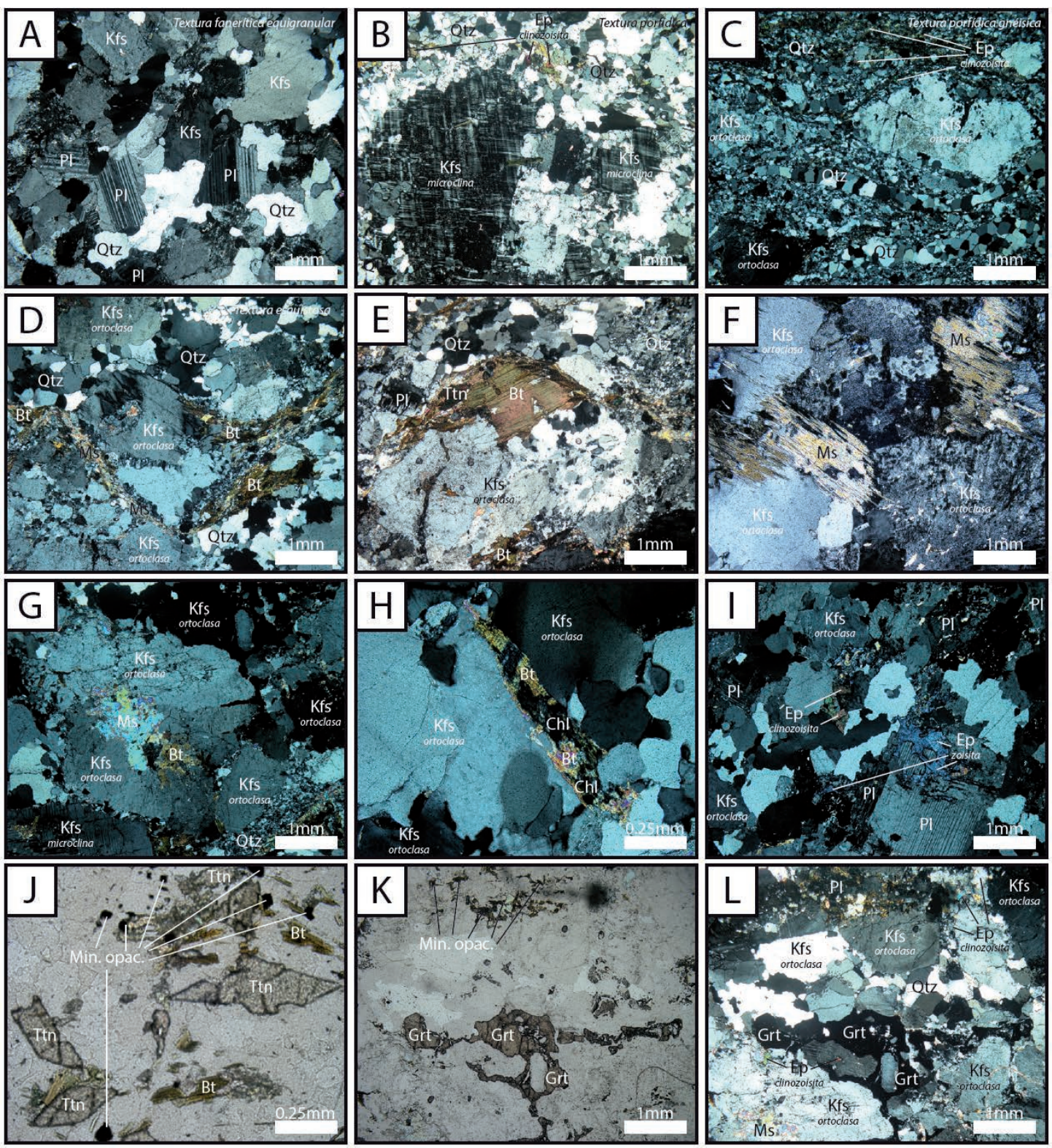

Figura 7. Microfotografías mostrando el aspecto textural y la mineralogía general presentes en las muestras de granitoides permo-triásicos de Sierra Los Tanques. (A) y (B) Texturas representativas vistas en NX. La mayoría de las rocas muestran una textura fanerítica a porfídica con tamaño de grano de medio a grueso. Nótese en (A) la presencia de cristales equigranulares de plagioclasa, feldespato y cuarzo, y en (B) la presencia de un fenocristal de microclina. (C) y (D) Algunas rocas muestran texturas gnéisicas-esquistosas (en NX) producto del metamorfismo de bajo grado presente en esta unidad granítica. (E) Cristal de biotita visto en NX con colores de interferencia rosa, amarillo y verde de segundo orden. (F) y (G) Cristales de moscovita vistos en NX. Este mineral aparece comúnmente en los granitoides como mineral primario en $(\mathrm{G})$, aunque en algunas ocasiones se encuentra alterada a clorita como en (F). (H) e (I) Algunos minerales secundarios, como la clorita y la epidota vistos en NX, también están presentes en los granitoides, frecuentemente la clorita reemplazando a la biotita como en $(\mathrm{H})$, y la epidota a la plagioclasa y/o feldespato como en (I). (J) Cristales rómbicos de titanita o esfena con alto relieve vistos en NII. Mineral accesorio muy común en la mayoría de estas rocas graníticas. (K) Cristales de granate mostrando relieves altos vistos en NII y cuya presencia en los granitoides es variable. (L) Misma microfotografía pero tomada en NX en donde se observan totalmente en extinción los cristales de granate debido a su carácter isótropo.

existe un patrón de foliación diferente con rumbos N-S, variando $5^{\circ}-10^{\circ} \mathrm{NW}$ con echados entre $45^{\circ}-65^{\circ}$ hacia el E-NE, foliación similar a las de las rocas de basamento paleoproterozoico presentes en la zona. En la porción central del sector sureste las foliaciones en los granitoides siguen siendo N-S con echados hacia el E-NE, mientras que en la porción más oriental, el patrón principal de las foliaciones cambia a rumbos NW-SE con echados hacia el SW, aunque existen rumbos N-S y echados contrarios hacia el E-NE (Figura 5) debido a que la deformación presente en esa zona está representada por plegamientos de la foliación.

Los dos grupos de granitoides, melanocrático y leucocrático, no presentan ninguna distribución preferencial espacialmente aunque en un afloramiento en el sector sureste 
de la sierra (Figura 5), los granitoides melanocráticos son más abundantes y son claramente intrusionados por los leucocráticos, cortando subparalelamente $\mathrm{y}$, en algunas ocasiones, perpendicularmente a su foliación. En esa zona en la parte más sureste de la Sierra Los Tanques justo al norte de la Sierra Cipriano (Figura 5), existe un afloramiento de gran importancia que se denominó como afloramiento Cerro Microondas, en donde se observan relaciones de campo interesantes entre las unidades permo-triásicas que ejemplifican la deformación pérmica-triásica presente en esa zona. En general, abundan los granitoides leucocráticos foliados de moscovita y granate, aunque existe una cantidad importante de granitoides melanocráticos (granodioritas y cuarzomonzodioritas de hornblenda y biotita), los cuales son cortados subparalelamente a su foliación por los leucocráticos (Figuras $8 \mathrm{C} \mathrm{y} \mathrm{D).} \mathrm{Estas} \mathrm{dos} \mathrm{unidades,}$
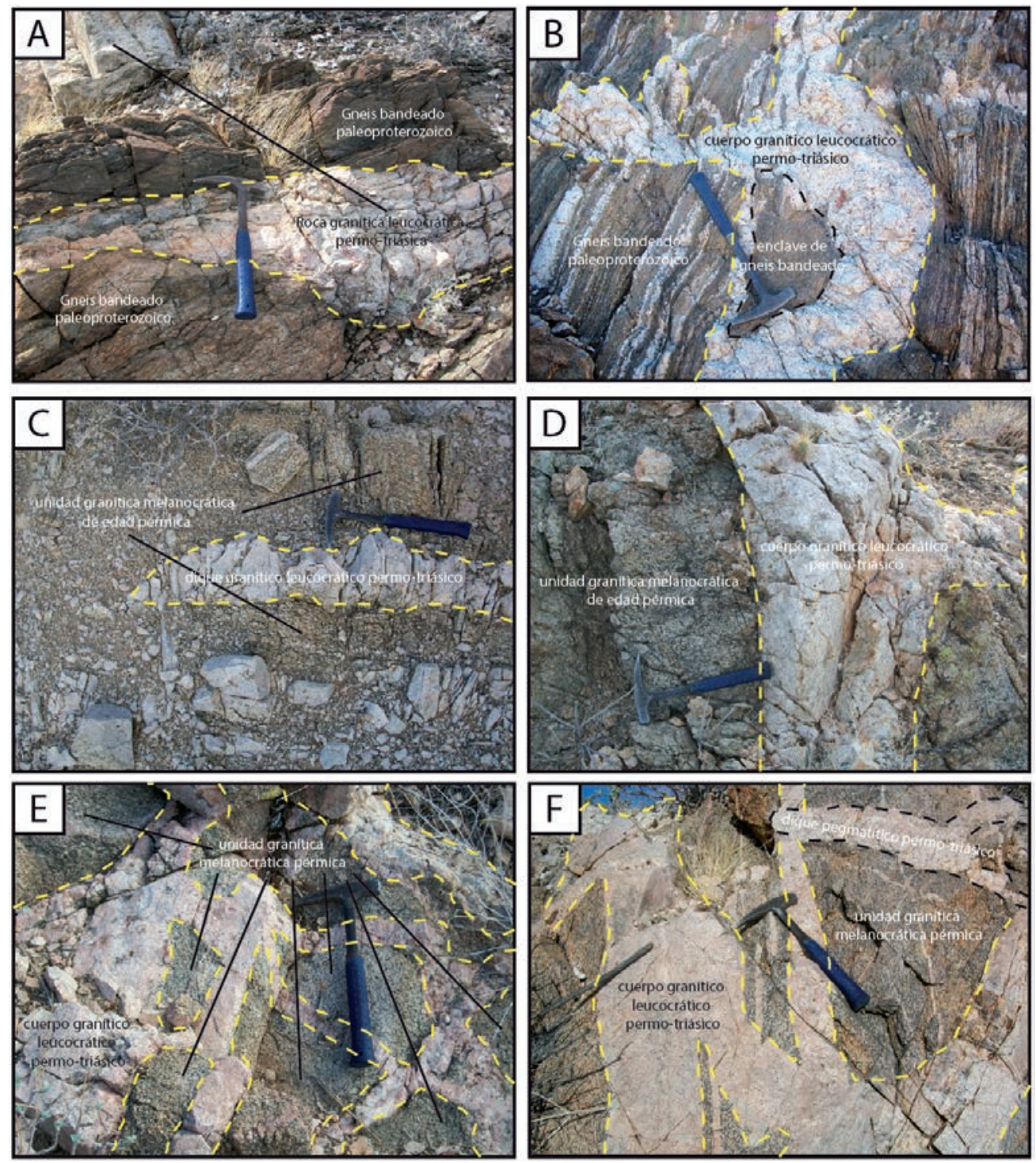

Figura 8. (A) y (B) Fotografías mostrando afloramientos representativos y relaciones de campo entre la unidad gnéisica paleoproterozoica y la unidad granítica permo-triásica de Sierra Los Tanques. (A) Vista de un afloramiento representativo en donde se observa a la unidad granítica leucocrática intrusionando subparalelamente y, a veces, perpendicularmente a la foliación de las rocas del basamento paleproterozoico. (B) Cuerpos graníticos leucocráticos en forma de diques pegmatíticos-aplíticos cortando paralelamente a la foliación de la unidad gnéisica. También se observan bloques o enclaves de gneises bandeados dentro de las masas graníticas permo-triásicas. (C-F) Fotografías mostrando afloramientos representativos y las relaciones de campo existentes entre los granitoides melanocráticos y leucocráticos de Sierra Los Tanques. En todos los casos se evidencia y muestra que la unidad granítica melanocrática (rocas oscuras) es cortada por la leucocrática (rocas claras). Todos los afloramientos están ubicados en el sector sureste del área de estudio, en los alrededores del afloramiento denominada Cerro Microondas. (C) y (D) Afloramientos en donde se observa a la unidad granítica leucocrática intrusionando paralelamente a la foliación de la unidad melanocrática como en A, y en algunas ocasiones cortando perpendicularmente a ésta como en (D). (E) y (F) Cuerpos graníticos leucocráticos en forma de diques pegmatíticos-aplíticos cortando a la unidad granitoide melanocrática pérmica. En (F) se puede observar que un dique pegmatítico corta tanto a la unidad leucocrática como a la melanocrática. Estos cuerpos pegmatíticos-aplíticos también son de edad permo-triásica (R. García, com. pers.). 
a su vez, son cortadas por diques pegmatíticos-aplíticos (Figuras 8 E y F) de edad permo-triásica (estrellas amarillas en las Figuras 2 y 5; R. García, com. pers., 2015), los cuales contienen abundante granate. En algunas zonas, se observan bloques y/o xenolitos de la unidad melanocrática dentro de la leucocrática. En ambas unidades graníticas permo-triásicas también existen bloques o xenolitos de la unidad gnéisica paleoproterozoica, la cual es cortada por los granitoides melanocráticos y leucocráticos, y por los diques leucocráticos aplíticos-pegmatíticos. De la unidad melanocrática se realizaron fechamientos $\mathrm{U}-\mathrm{Pb}$ en zircón proporcionando edades entre $267-250 \mathrm{Ma}$ (R. García, com. pers., 2015; Figuras 2 y 5).

El conjunto de diques de aplitas-pegmatitas, que cortan a los granitoides permo-triásicos y a los gneises bandeados paleoproterozoicos, generalmente se presentan a una escala menor de unos pocos centímetros de espesor hasta $\sim 1 \mathrm{~m}$, pero sin llegar a ser cartografiables. Las aplitas son de color blanco y de grano medio a fino $(0.5-1.0 \mathrm{~mm})$, compuestas principalmente por cuarzo y feldespato, con cantidades moderadas de moscovita y con menor abundancia de biotita; además muestran pequeñas cantidades de granate. Las pegmatitas presentan texturas porfídicas representadas por una matriz de grano fino a medio con grandes fenocristales de feldespato y plagioclasa y con moderada cantidad de granate. Ambos diques graníticos (aplíticos y pegmatíticos) comúnmente presentan forma tabular, a veces bifurcados. En algunas zonas muestran una foliación incipiente $\mathrm{y}$, debido a la deformación presente en el área, a veces se muestran abudinados. Existen fechamientos U-Pb en zircón en tres muestras pegmatíticas-aplíticas, cuyas composiciones varían entre granodiorita, cuarzosienita y monzogranito, proporcionando edades permo-triásicas entre $261-251 \mathrm{Ma}$ (R. García, com. pers., 2015; Figuras 2 y 5).

2.3.2.2. Jurásico Medio-Superior. En el área de estudio aflora una unidad metavolcánica-metasedimentaria del Jurásico Medio (R. García, com. pers., 2015), relacionado a la actividad de un arco magmático continental activo durante ese tiempo (Izaguirre-Pompa, 2009). Esta unidad está afectada por metamorfismo de bajo grado en facies de esquistos verdes y consiste principalmente en metariolitas y metandesitas. También están presentes rocas metavolcánicas esquistosas, filíticas y a veces gnéisicas con diferentes grados de deformación-milonitización. Los afloramientos de mayor extensión se localizan en la parte más oriental del área de estudio, en el sector sureste y en los alrededores del poblado de Sonoyta (Figuras 2 y 5). Por ejemplo, en la Sierra Los Tanques (Figura 5), esta unidad se encuentra en contacto discordante con las rocas más antiguas (unidad gnéisica paleoproterozoica) en la parte norte y más hacia el sur con la unidad granítica permo-triásica. Se han determinado edades $\mathrm{U}-\mathrm{Pb}$ en zircón para los protolitos de estas rocas en un rango aproximado entre $176-164 \mathrm{Ma}$ (R. García, com. pers., 2015; Figuras 2 y 5). Las foliaciones de esta unidad son variables predominando una familia con rumbos NW-
SE y echados entre $40^{\circ}-80^{\circ}$ hacia el NE. Algunas otras mediciones tienen buzamientos opuestos a esta familia debido a la deformación y plegamiento posteriores. Otro de los afloramientos de esta unidad jurásica se ubica en la parte noroeste de Lomas El Berrendo (Figura 2), en donde se expone una metariolita que está en contacto con la unidad de granito mesoproterozoico; en esa zona el contacto es de tipo intrusivo. Existe un fechamiento de U-Pb en zircones de $\sim 180$ Ma de una de estas rocas volcánicas (Campbell y Anderson, 2003) y otro más reciente, por el mismo método, de $\sim 170$ Ma (R. García, com. pers., 2015; Figuras 2 y 5).

2.3.2.3. Cretácico Superior. Extensos afloramientos de rocas graníticas de edad laramídica correspondientes al cinturón batolítico sonorense (e.g., Damon et al., 1983) afloran en los alrededores de la zona de estudio. Estas rocas varían entre granitos y monzogranitos de biotita o de dos micas, cuarzodioritas y cuarzomonzodioritas, predominando las granodioritas de biotita y/o hornblenda. Las expresiones más antiguas del magmatismo laramídico están representadas por pequeños cuerpos dioríticos ubicados en los sectores central y noroeste del área de estudio (Figuras 2, 3 y 4). El cuerpo más antiguo corresponde a una diorita de grano medio-grueso de $\sim 78 \mathrm{Ma}$ (R. García, com. pers., 2015) que corta a la unidad permo-triásica. Otros cuerpos corresponden a una cuarzomonzodiorita y una microdiorita con edades $\mathrm{U}-\mathrm{Pb}$ en zircones determinadas por Arvizu-Gutiérrez (2012) de $75.4 \pm 0.3$ Ma y $72.7 \pm 0.6 \mathrm{Ma}$, respectivamente, y que también intrusionan a rocas permo-triásicas. Existe también un fechamiento U-Pb en zircones de $\sim 68 \mathrm{Ma}$ (R. García, com. pers., 2015; ver estrellas de color amarillo en las Figuras 2 y 3 ) en una muestra de granito de biotita que corta localmente al basamento paleoproterozoico en el sector central (Figura 4). En la región también aflora un cuerpo granítico de edad laramídica de gran extensión llamado Cerro El Papalote (Figuras 2 y 3 ) en donde también existe un fechamiento $\mathrm{U}-\mathrm{Pb}$ en zircones de $\sim 73 \mathrm{Ma}$ (R. García, com. pers., 2015; ver estrellas amarillas en las Figuras 2 y 3). Otras ocurrencias de este magmatismo del Cretácico Superior se localizan al sureste del área de estudio (Figura 2) en donde sobresalen dos grandes cuerpos graníticos que se identifican fácilmente por su elevada topografía; estos son la Sierra Cipriano y la Sierra Cubabi. En la Sierra Cipriano se han determinado edades $\mathrm{U}-\mathrm{Pb}$ en zircones de $\sim 68 \mathrm{Ma}$, mientras que para la Sierra Cubabi existen edades de cristalización de $\sim 65$ Ma (R. García, com. pers., 2015; ver estrellas amarillas para la ubicación en las Figuras 2 y 5). En la Sierra Cubabi, también se tiene el control temporal de aplitas y pegmatitas que cortan al plutón principal con edades de 62 y $59 \mathrm{Ma}$, respectivamente (R. García, com. pers., 2015). Estas edades más jóvenes, junto con la edad U-Pb en zircones determinada por Arvizu-Gutiérrez (2012) de $63.2 \pm 0.6 \mathrm{Ma}$ de una muestra de granito de dos micas, ubicada en el sector sureste de la Sierra Los Tanques (Figura 5), representan las expresiones del magmatismo laramídico más joven en la región. 


\subsubsection{Cenozoico}

2.3.3.1. Mioceno. La presencia de un pulso magmático miocénico en la Sierra Los Tanques está representado por rocas volcánicas de composición basáltico-andesítica y por lavas riolíticas (e.g., Cerro Los Vidrios; Figuras 2 y 3 ). Una muestra de riolita de Cerros Los Vidrios, ubicada en el sector noroeste de la Sierra Los Tanques (Figura 3), fue fechada por Arvizu-Gutiérrez (2012) por el método U-Pb en zircones proporcionando una edad de $14.17 \pm 0.13 \mathrm{Ma}$. Otro fechamiento de esta misma unidad riolítica, realizado anteriormente por Vidal-Solano et al. (2008) por el método ${ }^{40} \mathrm{Ar} /{ }^{39} \mathrm{Ar}$ en roca total, arroja una edad similar de $14.23 \pm$ $0.15 \mathrm{Ma}$. Más hacia el suroeste, aproximadamente a $5 \mathrm{~km}$ de Cerros Los Vidrios en la localidad de Los Vidrios Viejos (Figura 2) existe un fechamiento ${ }^{40} \mathrm{Ar} /{ }^{39} \mathrm{Ar}$ en obsidiana, también de esta unidad riolítica, de $14.27 \pm 0.87 \mathrm{Ma}$ (Vidal-Solano et al., 2008). Se ha determinado una edad de ${ }^{40} \mathrm{Ar} /{ }^{39} \mathrm{Ar}$ en matriz volcánica de un basalto en la parte norte del sector noroeste de la Sierra Los Tanques (Figura 3) de $\sim 22 \mathrm{Ma}$ (F. Paz, com. pers.). Una muestra de esta unidad basáltica fue fechada por Vidal-Solano et al. (2008) en 19.0 \pm 0.9 Ma por el mismo método pero en plagioclasa. Estas unidades lávicas miocénicas presentan basculamientos variables como reacción al pulso extensional Basin and Range presente en la región, mostrando en general, rumbos NW-SE con echados variables (aprox. $30^{\circ}-40^{\circ}$ ) hacia el NE y SW.

2.3.3.2. Cuaternario. Las rocas basálticas de edad cuaternaria y de composición alcalina que constituyen el Evento Volcánico El Pinacate (e.g., Gutmann, 1976, 1977, 1979, 1986, 2002; Lynch, 1981; Lynch et al., 1993; Gutmann et al., 2000), son encontradas coronando la mayoría de los afloramientos de la región. Cubriendo discordantemente a las rocas más antiguas afloran depósitos no consolidados del Cuaternario, constituidos por coluvión, aluvión y eólicos compuestos principalmente de gravas, arenas, limos y arcillas distribuidos al pie de las montañas y algunos otros cubriendo los amplios valles y rellenando cuencas locales (Figuras 2 - 5). Los sedimentos arcilloarenosos transportados por acción eólica forman y modelan grandes dunas de arena.

\section{Geocronología U-Pb en zircón de granitoides permo- triásicos de la Sierra Los Tanques}

\subsection{Introducción}

Un total de 12 muestras de granitoides permo-triásicos fueron fechadas por el método geocronológico $\mathrm{U}-\mathrm{Pb}$ en zircón para determinar las edades de cristalización utilizando la técnica de Ablación Láser y Espectrometría de Masas con Plasma Acoplado Inductivamente (LAICPMS, Laser Ablation-Inductively Coupled Plasma
Mass Spectrometry Ablación Láser y Espectrometría de Masas con Plasma Acoplado Inductivamente; ver técnica analítica en Suplemento Electrónico). Todas estas muestras representativas fueron seleccionadas de diversos afloramientos ubicados en diferentes sectores del área de estudio (Figuras $2-5$ ) con el fin de obtener un mejor control temporal del evento permo-triásico. Un promedio de 35 zircones para cada muestra fueron seleccionados y utilizados para realizar los análisis in situ U-Pb en zircón.

A continuación se describen de forma general, las características de los zircones analizados y los resultados geocronológicos $\mathrm{U}-\mathrm{Pb}$ de las muestras. Los datos geocronológicos obtenidos (diagramas de concordia $\mathrm{U}-\mathrm{Pb}$ ), además de imágenes de catodoluminiscencia de algunos de los zircones fechados más representativos de cada muestra, donde se observa el punto de ablación y la edad obtenida en ese punto del zircón se muestran en las Figuras 9-12. Todos los datos se reportan en la Tabla SE1 en el Suplemento Electrónico. Por otro lado, en la Tabla 1 se enlista un resumen de las edades permo-triásicas obtenidas, además de la localización de muestras y mineralogía de las diferentes unidades graníticas fechadas.

\subsection{Descripción de zircones}

Alrededor de 100 granos de zircón de cada muestra fueron estudiados utilizando imágenes de luz reflejada y transmitida, además de imágenes de catodoluminiscencia. Algunas imágenes de zircones representativos de cada muestra son mostradas en las Figuras 9-12. Vistos en luz transmitida, los zircones de todas las muestras comparten características similares: tienen formas euhedrales a subhedrales, la mayoría son incoloros, algunos granos exhiben tonos amarillos, además, la mayoría de los cristales muestran inclusiones. Las morfologías de los zircones principalmente son prismas bipiramidales alargados con bordes y puntas bien definidas, algunas veces ligeramente redondeadas, con relaciones de aspecto entre 1:3 y 1:4. Algunos cristales exhiben morfologías prismáticas cortas y anchas (stubby prisms), aunque predominando las primeras. Los tamaños son variables entre $100-350 \mu \mathrm{m}$ pero la mayoría rebasando los $200 \mu \mathrm{m}$ y los más grandes con tamaños $>300 \mu \mathrm{m}$.

Por otro lado, las imágenes de catodoluminiscencia (Figuras $9-12$ D, H y L) revelan la naturaleza ígnea de los zircones mostrando estructuras internas típicas de crecimiento magmático con una zonación oscilatoria bien definida para la mayoría de los zircones. La mayoría de estos muestra una buena luminiscencia, revelando zonaciones oscilatorias suavemente marcadas en algunos granos. Otros cristales no exhiben una clara zonación oscilatoria sino que muestran una zonación más homogénea. Se ablacionaron intencionalmente los dominios zonados para determinar la edad de cristalización de cada roca (Figuras 9-12 D, H y L; Tabla SE1). Otra característica muy común $\mathrm{y}$ distintiva de los zircones de estos granitoides permo- 
triásicos es la presencia significativa de semillas o núcleos heredados que se distinguen fácilmente por presentar una alta luminiscencia y por ser redondeados (Figuras $9-12$ D, H y L). Más del $50 \%$ de los zircones de cada muestra presentan esta característica. Cabe señalar, que algunas de estas herencias fueron confirmadas por las edades $\mathrm{U}-\mathrm{Pb}$ individuales obtenidas de algunos zircones $(>1.0 \mathrm{Ga}$, predominando un rango aproximado entre $1.6-1.8 \mathrm{Ga}$ ) (Figuras 9-12 D, H y L; Tabla SE1). En la mayoría de los zircones se muestra alta luminiscencia y zonaciones magmáticas oscilatorias bien definidas, algunos otros granos solamente muestran un núcleo heredado bordeado por un dominio más oscuro rico en U como lo indican las altas concentraciones (ppm) de ese elemento (Figuras 9-12D, $\mathrm{H}$ y L; Tabla SE1). Algunos zircones muestran estructuras internas o texturas complejas no muy comunes en zircones magmáticos (Figuras 9-12 D, H y L), quizá producto de recristalización por metamorfismo o hidrotermalismo como lo revelan algunas de las relaciones muy bajas de $\mathrm{Th} / \mathrm{U}(\leq$ 0.02, Tabla SE1).

\subsection{Resultados}

\subsubsection{Granodiorita de biotita (TANW09-06)}

El contenido de $U$ es alto en un rango entre $277-2904$ ppm y las concentraciones de Th varían de 56-419 ppm. Las relaciones $\mathrm{Th} / \mathrm{U}$ varían de $0.06-0.27$ (Tabla SE1). Se observan algunos zircones discordantes $(2-14 \%)$ que representan herencias con edades proterozoicas. Destaca la presencia de un zircón heredado con edad ${ }^{207} \mathrm{~Pb} /{ }^{206} \mathrm{~Pb}$ de $1700 \pm 17 \mathrm{Ma}$ (zircón/análisis 15, Figura 9A; Tabla SE1). Por otro lado, los análisis más jóvenes (Figura 9B) muestran una dispersión a lo largo de la línea de concordia con diferentes grados de discordancia, debido a que representan zircones que han sufrido pérdida de $\mathrm{Pb}$, o en el caso de zircones más viejos, representan herencias. Se determinó una edad ${ }^{206} \mathrm{~Pb} / 238 \mathrm{U}$ media ponderada de $257 \pm 5 \mathrm{Ma}(2 \mathrm{~s}$, MSWD $=2.4, n=4$; Figura 9C) para ésta granodiorita de biotita.

\subsubsection{Gneis de biotita (GneisSur-1)}

Las concentraciones de U varían de $332-6125$ ppm; las más altas pertenecen a los zircones más jóvenes a lo largo de la línea de concordia que han perdido $\mathrm{Pb}$ (Figura 9E), lo cual también es confirmado por los dominios más oscuros ricos en U (Figura 9H; Tabla SE1). El contenido de Th es bajo variando de $4-331 \mathrm{ppm}$, mientras que las relaciones $\mathrm{Th} / \mathrm{U}$ tienen un rango entre $0.01-0.32$. Se observa una población importante pero dispersa de zircones con edades permo-triásicas con diversos grados de discordancia $(0-9 \%)$ (Figura 9F). Algunos de estos análisis también representan la presencia de $\mathrm{Pb}$ común, efecto que puede deducirse cuando la edad ${ }^{208} \mathrm{~Pb} /{ }^{232} \mathrm{Th}$ del zircón es más vieja que la edad ${ }^{206} \mathrm{~Pb} /{ }^{238} \mathrm{U}$ (Tabla SE1). Los análisis relativamente concordantes $(\leq 3 \%)$, proporcionan una edad ${ }^{206} \mathrm{~Pb} /{ }^{238} \mathrm{U}$ media ponderada de $255 \pm 3 \mathrm{Ma}(2 \mathrm{~s}$,
MSWD $=2.3, \mathrm{n}=8$; Figura 9G) que se interpreta como la edad de cristalización del protolito de esta roca gnéisica.

\subsubsection{Granodiorita leucocrática de biotita y granate (aplita) (TANSE09-01)}

Las concentraciones de $\mathrm{U}$ y $\mathrm{Pb}$ para los zircones son de $47-1479$ ppm y $1-137$ ppm, respectivamente, con relaciones $\mathrm{Th} / \mathrm{U}$ entre $0.01-0.36$ (Tabla SE1). Presencia de zircones heredados, identificados en las imágenes de catodoluminiscencia con edades proterozoicas entre 1.2 - 1.6 Ga (e.g., zircón/análisis 3, 6, 8, 19 y 25; Tabla $\mathrm{SE} 1)$, ligeramente discordantes $(1-5 \%)$ (Figura 9I). Los datos más jóvenes de edad permo-triásica muestran una dispersión a lo largo de la concordia; algunos datos son relativamente concordantes (-2 a $2 \%$ ) y otros muestran pérdida de $\mathrm{Pb}$ (Figura 9J). Se determinó una edad ${ }^{206} \mathrm{~Pb} /{ }^{238} \mathrm{U}$ media ponderada de $254 \pm 2 \mathrm{Ma}(2 \mathrm{~s}, \mathrm{MSWD}=2.5, \mathrm{n}=5$; Figura $9 \mathrm{~K}$ ), interpretada como la edad de cristalización de este leucogranito con granate.

\subsubsection{Monzogranito de biotita (CG09-10)}

Los contenidos de U son de $260-3584$ ppm (Tabla SE1). Los valores más altos de 3584 ppm y 1908 ppm corresponden a los análisis más jóvenes (zircón/análisis 32 y 15; Tabla SE1) con pérdida de $\mathrm{Pb}$, los cuales se muestran a lo largo de la concordia (Figura 10B). Las concentraciones de Th varían de $7-1505$ ppm mientras que las relaciones $\mathrm{Th} / \mathrm{U}$ se encuentran en un rango entre $0.01-0.73$, predominando los valores $>0.1$ (Tabla SE1), típicas de zircones magmáticos. Se observan zircones heredados de edad mesoproterozoica con diversos grados de discordancia $(<5 \%$ y $>10 \%$, Tabla SE1). Cabe destacar la presencia de dos zircones concordantes ( 0 y $1 \%)$ con edades ${ }^{207} \mathrm{~Pb} /{ }^{206} \mathrm{~Pb}$ de $1090 \pm 19 \mathrm{Ma}$ y $1443 \pm 18 \mathrm{Ma}$ (Figura $10 \mathrm{~A}$ ). Los datos más jóvenes de edades permo-triásicas muestran una población de datos relativamente concordantes (Figura 10B) empleados para calcular una edad ${ }^{206} \mathrm{~Pb} /{ }^{238} \mathrm{U}$ media ponderada de $254 \pm 3 \mathrm{Ma}(2 \mathrm{~s}, \mathrm{MSWD}=1.9, \mathrm{n}=9$; Figura 10C), la cual se interpreta como la edad de cristalización del monzogranito de biotita.

\subsubsection{Granodiorita leucocrática de biotita (TANSE-09)}

Las concentraciones de U oscilan de $207-4518$ ppm (Tabla SE1). Los valores más altos de U (2165 - 4518 ppm) representan los análisis más jóvenes que han experimentado pérdida de $\mathrm{Pb}$. El contenido de Th varía entre $28-551$ $\mathrm{ppm}$ con relaciones $\mathrm{Th} / \mathrm{U}$ en un rango entre $0.03-0.42$, prevaleciendo los valores $>0.1$ (Tabla SE1). Existe un número elevado de zircones heredados de edad proterozoica $(1591-1758 \mathrm{Ma})$ con diferentes grados de discordancia (-2\% a $10 \%$ ) (Figura 10E). Se destaca la presencia de dos análisis concordantes con edades de $1351 \pm 28 \mathrm{Ma}$ y $1643 \pm 20 \mathrm{Ma}$ (Tabla SE1). Un acercamiento a los zircones más jóvenes de edad permo-triásica (Figura 10F) muestra una población de análisis relativamente concordantes $(<$ $4 \%$ ), los cuales fueron empleados para calcular una edad 

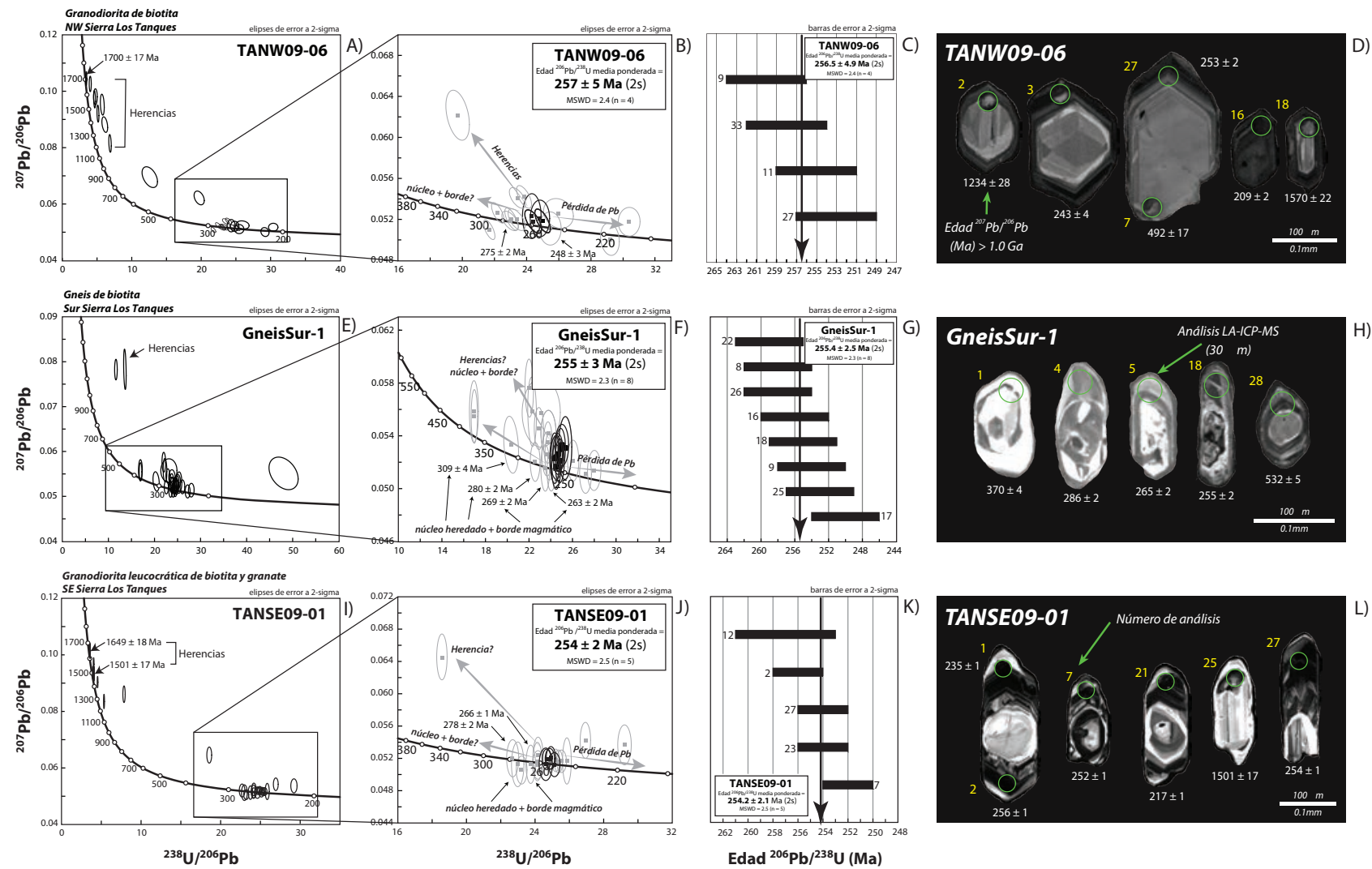

Figura 9. Datos analíticos de U-Pb obtenidos de zircones de granitoides pérmicos de Sierra Los Tanques utilizando la técnica de ablación láser (LAICP-MS). (A), (E) e (I) Gráficos de concordia tipo Tera-Wasserburg mostrando todos los datos de los zircones analizados de las muestras TANW09-06, GneisSur-1 y TANSE09-01. (B), (F) y (J) Acercamientos a los datos más jóvenes en donde se muestra la edad ${ }^{206} \mathrm{~Pb} /{ }^{238} \mathrm{U}$ media ponderada calculada para cada muestra. Los análisis representados por las elipses y cuadrados de color negro fueron empleados para el cálculo de la edad media ponderada, mientras que los análisis en color gris (elipses y cuadrados) fueron descartados para este cálculo debido a que representan zircones con herencias y/o pérdida de $\mathrm{Pb}$. $(\mathrm{C}),(\mathrm{G})$ y $(\mathrm{K})$ Gráficos de media ponderada mostrando los análisis empleados para calcular la edad media ponderada. (D), (H) y (L) Imágenes de catodoluminiscencia de algunos zircones representativos de cada muestra, mostrando el lugar de ablación y debajo de cada zircón la edad determinada en ese punto del zircón.

${ }^{206} \mathrm{~Pb} /{ }^{238} \mathrm{U}$ media ponderada de $252 \pm 3 \mathrm{Ma}(2 \mathrm{~s}, \mathrm{MSWD}=$ $0.69, \mathrm{n}=7$; Figura 10G) para este leucogranito de biotita. Los análisis más jóvenes no fueron utilizados para este cálculo debido a que representan zircones que han sufrido pérdida de $\mathrm{Pb}$ como lo indican las concentraciones altas de U (2165 - 4518 ppm; Tabla SE1).

\subsubsection{Cuarzomonzodiorita de biotita (MICRO-3)}

Las concentraciones de $\mathrm{U}$ y Th para los zircones analizados son de $394-4248 \mathrm{ppm}$ y de $51-780 \mathrm{ppm}$, respectivamente, con relaciones $\mathrm{Th} / \mathrm{U}$ que varían en un rango entre $0.08-0.25$. Los valores más altos de U pertenecen a los análisis más jóvenes que pudieran representar zircones con pérdida de $\mathrm{Pb}$. Se observa poca presencia de herencias, destacando un zircón heredado concordante con una edad ${ }^{207} \mathrm{~Pb} /{ }^{206} \mathrm{~Pb}$ de $1716 \pm 18 \mathrm{Ma}$ (Figura 10I). Un acercamiento a los análisis más jóvenes (Figura 10J) permite visualizar una gran dispersión de datos con diversos grados de discordancia, aunque existen algunos análisis relativamente más concordantes entre -1 \% y $3 \%$. Se determinó una edad ${ }^{206} \mathrm{~Pb}^{238} \mathrm{U}$ media ponderada de $243 \pm 2 \mathrm{Ma}(2 \mathrm{~s}, \mathrm{MSWD}=0.23, \mathrm{n}=5$; Figura $10 \mathrm{~K})$ para la muestra de cuarzomonzodiorita de biotita. Los análisis más jóvenes claramente han sufrido pérdida de $\mathrm{Pb}$ como lo podrían indicar los elevados contenidos de $\mathrm{U}$ de esos zircones (Tabla SE1).

\subsubsection{Granodiorita leucocrática de biotita (GranCen-5)}

Los zircones tienen de moderadas a altas concentraciones de Uy Th (395 - 2106 ppm y 26-827 ppm, respectivamente) con relaciones $\mathrm{Th} / \mathrm{U}$ que varían entre $0.05-0.47$, predominando los valores $>0.1$ (Tabla SE1). Se observan algunos análisis altamente discordantes $>3 \%$ (entre $3-$ $22 \%$ ) que representan zircones heredados (e.g., zircón/ análisis 18, 20, 21, 25 y 30) (Figura 11A). Un acercamiento a los análisis más jóvenes muestra una población de datos dispersos, relativamente concordantes $(\leq 3 \%)$ a lo largo de la línea de concordia (Figura 11B). Se determinó una edad ${ }^{206} \mathrm{~Pb} /{ }^{238} \mathrm{U}$ media ponderada de $240 \pm 3 \mathrm{Ma}(2 \mathrm{~s}, \mathrm{MSWD}=$ $1.5, \mathrm{n}=5$; Figura 11C) para la granodiorita leucocrática de 

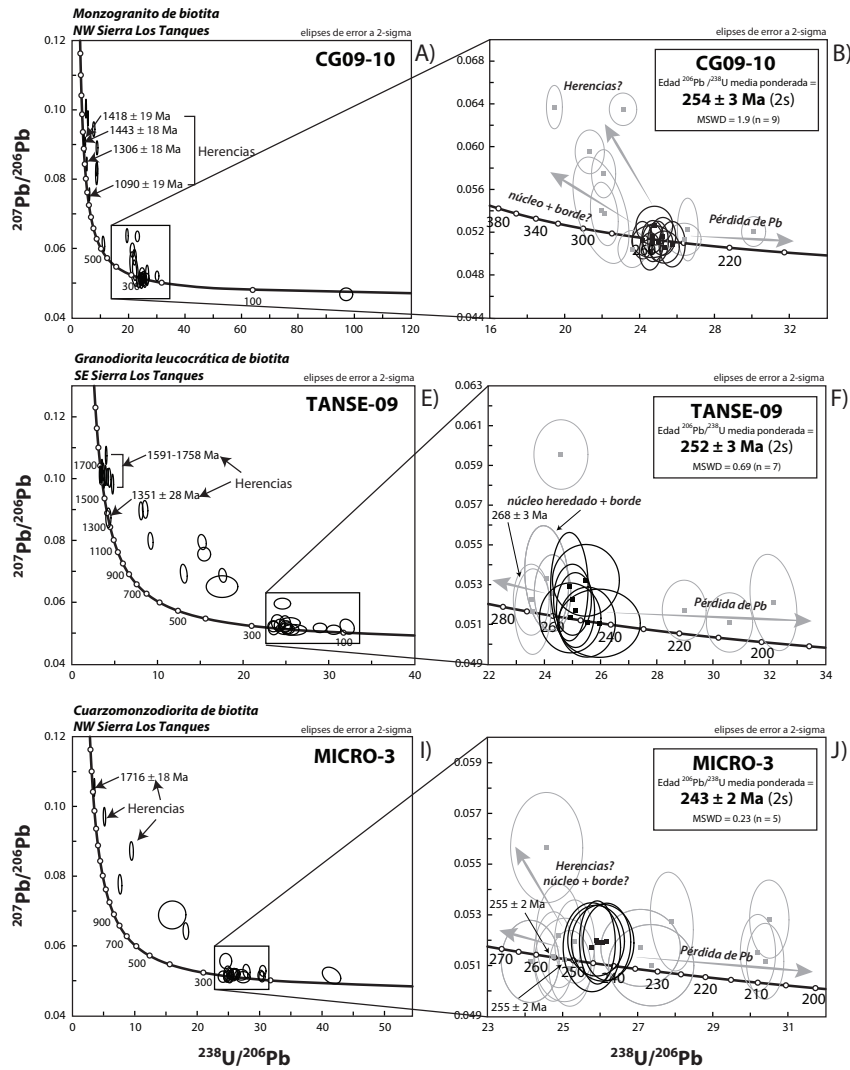
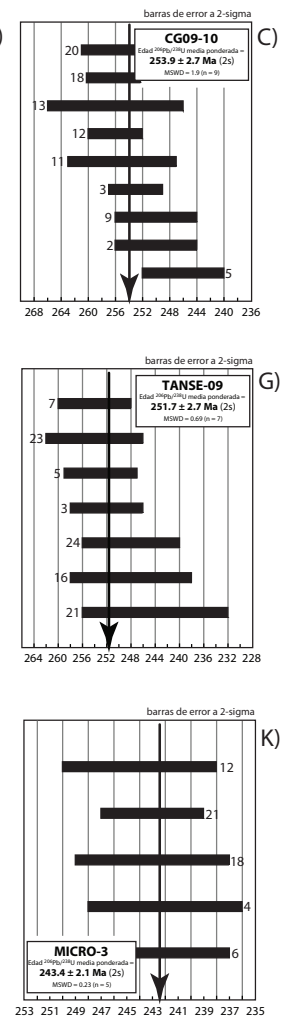

Edad ${ }^{206} \mathrm{~Pb} /{ }^{238} \mathrm{U}(\mathrm{Ma})$
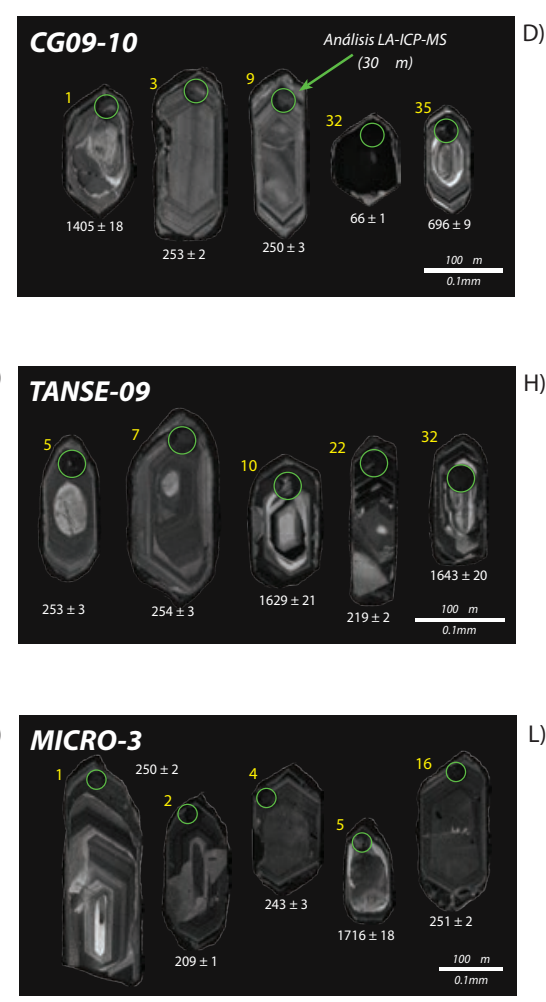
.

Figura 10. Datos analíticos de U-Pb obtenidos de zircones de granitoides pérmicos de Sierra Los Tanques utilizando la técnica de ablación láser (LA-ICPMS). (A), (E) e (I) Gráficos de concordia tipo Tera-Wasserburg mostrando todos los datos de los zircones analizados de las muestras CG09-10, TANSE-09 y MICRO-3. (B), (F) y (J) Acercamientos a los datos más jóvenes en donde se muestra la edad ${ }^{206} \mathrm{~Pb} /{ }^{238} \mathrm{U}$ media ponderada calculada para cada muestra. Los análisis representados por las elipses y cuadrados de color negro fueron empleados para el cálculo de la edad media ponderada, mientras que los análisis en color gris (elipses y cuadrados) fueron descartados para este cálculo debido a que representan zircones con herencias y/o pérdida de Pb. (C), (G) y (K) Gráficos de media ponderada mostrando los análisis empleados para calcular la edad media ponderada. (D), (H) y (L) Imágenes de catodoluminiscencia de algunos zircones representativos de cada muestra, mostrando el lugar de ablación y debajo de cada zircón la edad determinada en ese punto del zircón.

biotita. El resto de los análisis, que se representan como elipses y cuadrados de color gris, no fueron usados para calcular la edad media ponderada debido a que representan zircones que han experimentado pérdida de $\mathrm{Pb}$ (análisis más jóvenes con altas concentraciones de U; Tabla SE1) y/o son zircones en donde simplemente se han muestreado dominios del zircón un poco más viejos.

\subsubsection{Granodiorita leucocrática de dos micas (TANW09- 01)}

Los contenidos de $\mathrm{U}$ y Th para los zircones analizados son moderados variando de $18-1097 \mathrm{ppm}$ y de $6-183$ $\mathrm{ppm}$, respectivamente, con relaciones Th/U $0.01-0.70$ prevaleciendo valores $>0.1$ (Tabla SE1). Existe la presencia de herencias, destacando la presencia de tres análisis concordantes $(\leq 3 \%)$ con edades ${ }^{207} \mathrm{~Pb} /{ }^{206} \mathrm{~Pb}$ de $1111 \pm 52$ Ma, $1476 \pm 17$ Ma y $1612 \pm 17$ Ma (Figura 11E). Otros tres análisis con discordancias altas, representan zircones con diferentes grados de herencia (e.g., zircón/análisis 3, 8 y 23 Figura 11E; Tabla SE1). Un acercamiento a los análisis más jóvenes (Figura 11F) muestra una dispersión significativa a lo largo de la línea de concordia de los datos que son relativamente concordantes (- $1 \%$ a $2 \%$ ). Una agrupación de análisis concordantes, representados por las elipses y cuadrados de color negro, fueron usados para el cálculo de una edad ${ }^{206} \mathrm{~Pb} /{ }^{238} \mathrm{U}$ media ponderada de $238 \pm 1 \mathrm{Ma}(2 \mathrm{~s}$, $\operatorname{MSWD}=1.8, \mathrm{n}=12$; Figura $11 \mathrm{G}$ ), interpretada como la edad de cristalización de esta granodiorita leucocrática de dos micas.

\subsubsection{Granodiorita leucocrática de biotita (TANC09-04)}

El contenido de U para los zircones analizados va de $66-2495 \mathrm{ppm}$ y de Th va de $12-1302 \mathrm{ppm}$ con relaciones $\mathrm{Th} / \mathrm{U}$ que varían entre $0.07-0.59$, predominando valores altos $>0.1$ (Tabla SE1). Existe un gran número de zircones heredados de edades proterozoicas ${ }^{207} \mathrm{~Pb} /{ }^{206} \mathrm{~Pb}$ entre 1183 - $1934 \mathrm{Ma}$ (Figura 11I), pero con diversos grados de discordancia (>10\%, Tabla SE1). Los análisis más discordantes tienen valores entre $10-42 \%$ de discordancia, mientras que los menos discordantes tienen valores $<5 \%$ (Tabla SE1). Cabe destacar tres análisis concordantes $(0-$ $1 \%$ ) con edades ${ }^{207} \mathrm{~Pb} /{ }^{206} \mathrm{~Pb}$ de $1191 \pm 20 \mathrm{Ma}, 1598 \pm 17$ Ma y $1720 \pm 17$ Ma. En el acercamiento a los datos más jóvenes (Figura 11J) se observa una agrupación de análisis 

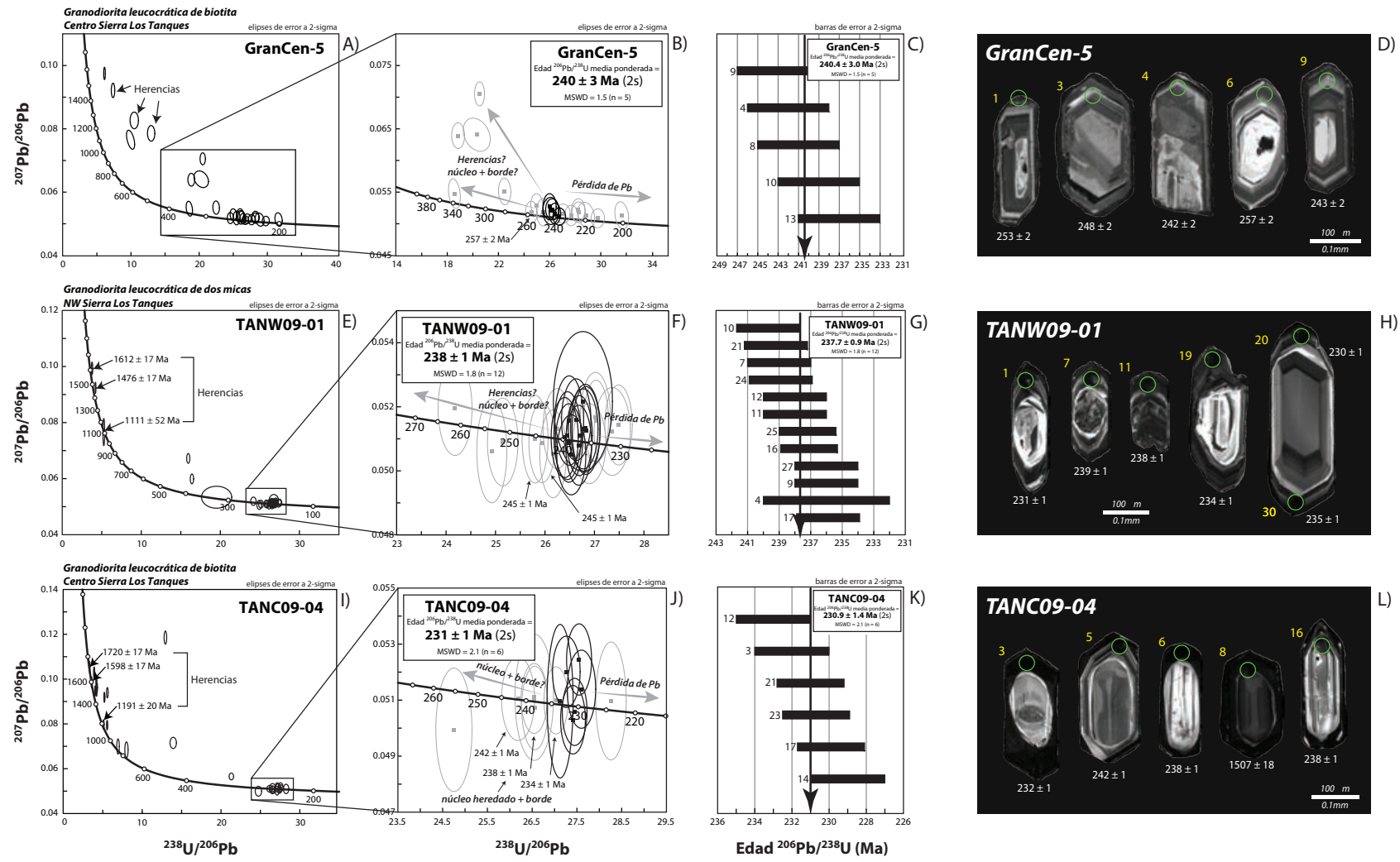

Figura 11. Datos analíticos de U-Pb obtenidos de zircones de granitoides pérmicos de Sierra Los Tanques utilizando la técnica de ablación láser (LAICP-MS). (A), (E) e (I) Gráficos de concordia tipo Tera-Wasserburg mostrando todos los datos de los zircones analizados de las muestras GranCen-5, TANW09-01 y TANC09-04. (B), (F) y (J) Acercamientos a los datos más jóvenes en donde se muestra la edad ${ }^{206} \mathrm{~Pb} /{ }^{238} \mathrm{U}$ media ponderada calculada para cada muestra. Los análisis representados por las elipses y cuadrados de color negro fueron empleados para el cálculo de la edad media ponderada, mientras que los análisis en color gris (elipses y cuadrados) fueron descartados para este cálculo debido a que representan zircones con herencias y/o pérdida de $\mathrm{Pb}$. $(\mathrm{C}),(\mathrm{G})$ y $(\mathrm{K})$ Gráficos de media ponderada mostrando los análisis empleados para calcular la edad media ponderada. (D), (H) y (L) Imágenes de catodoluminiscencia de algunos zircones representativos de cada muestra, mostrando el lugar de ablación y debajo de cada zircón la edad determinada en ese punto del zircón.

representados por elipses y cuadrados de color negro, que han sido empleados para calcular una edad ${ }^{206} \mathrm{~Pb} /{ }^{238} \mathrm{U}$ media ponderada de $231 \pm 1 \mathrm{Ma}(2 \mathrm{~s}, \mathrm{MSWD}=2.1, \mathrm{n}=6$; Figura $11 \mathrm{~K})$, la cual es interpretada como la edad de cristalización de la granodiorita leucocrática de biotita.

\subsubsection{Granodiorita leucocrática de biotita (LeucoCen-1)}

Las concentraciones de $\mathrm{U}$ de los zircones van de 75 - 6455 ppm, algunas de las más altas corresponden a los análisis más jóvenes que se interpreta han sufrido pérdida de $\mathrm{Pb}$. Por su parte, los contenidos de Th van de 3-1979 ppm con relaciones $\mathrm{Th} / \mathrm{U}$ en un rango que varía de $0.01-0.60$ (Tabla SE1). Se corrobora la existencia de varios zircones heredados que presentan diferentes grados de discordancia, destacando la presencia de tres análisis relativamente concordantes $(<2 \%)$ con edades proterozoicas ${ }^{207} \mathrm{~Pb} /{ }^{206} \mathrm{~Pb}$ de $1058 \pm 21 \mathrm{Ma}, 1287 \pm 29$ Ma y $1688 \pm 19 \mathrm{Ma}$ (Figura 12A). Un acercamiento a los datos más jóvenes (Figura 12B) permite visualizar una dispersión de los análisis con diferentes grados de discordancia a lo largo de la línea de concordia. Una población de zircones concordantes $(-1 \% \mathrm{a}$ $1 \%$ ) permite calcular una edad ${ }^{206} \mathrm{~Pb} /{ }^{238} \mathrm{U}$ media ponderada de $226 \pm 5 \mathrm{Ma}(2 \mathrm{~s}, \mathrm{MSWD}=1.6, \mathrm{n}=5$; Figura 12C) para este leucogranito de biotita. La agrupación de los análisis más jóvenes representa zircones que han experimentado una pérdida de $\mathrm{Pb}$, como lo sugieren las concentraciones altas de U (1928 - 6455 ppm; Tabla SE1), comparadas con el resto de los análisis de esta muestra.

\subsubsection{Granodiorita leucocrática de dos micas (GranCen-4)}

Los zircones analizados tienen concentraciones altas de U entre $344-3118$ ppm y contenidos de Th que varían de $36-549 \mathrm{ppm}$, con relaciones $\mathrm{Th} / \mathrm{U}$ que van de $0.02-0.26$ (Tabla SE1). Se observa una gran dispersión de los datos, los cuales poseen diferentes grados de discordancia (- $1 \%$ a $19 \%$ ) (Figura 12E). Los análisis con edades más antiguas, altamente discordantes $(>10 \%)$, representan zircones con algún grado de herencia. También existe una población de zircones más jóvenes, con mayor o menor grado de discordancia (aunque algunos muy concordantes), con edades entre 203-265 Ma que muestran gran dispersión a lo largo de la línea de concordia. Una agrupación de estos análisis, relativamente concordantes, permiten calcular una edad ${ }^{206} \mathrm{~Pb} /{ }^{238} \mathrm{U}$ media ponderada de $224 \pm 3 \mathrm{Ma}$ (2s, MSWD 
$=1.8, \mathrm{n}=5$; Figura $12 \mathrm{~F}$ ) que se interpreta como la edad de cristalización de esta granodiorita leucocrática de dos micas.

\subsubsection{Granodiorita leucocrática de dos micas (GranCen-3)}

Las concentraciones de $\mathrm{U}$ y $\mathrm{Th}$ para los zircones analizados son las más altas, comparadas con el resto de las muestras, variando de $604-9508$ ppm y $87-958$ $\mathrm{ppm}$, respectivamente, con relaciones $\mathrm{Th} / \mathrm{U}$ entre $0.03-$ 0.26 (Tabla SE1). Se observa una gran dispersión de los datos con diferentes grados de discordancia (- $1 \%$ a 13 $\%$ ), aunque algunos análisis son más concordantes que otros (entre - $1 \%$ y $3 \%$ ) (Figura $12 \mathrm{H}$ ). Una población de zircones representada por la agrupación de los análisis en color negro (elipses y cuadrados) fueron utilizados para el cálculo de una edad ${ }^{206} \mathrm{~Pb} /{ }^{238} \mathrm{U}$ media ponderada de $221 \pm 2$ $\operatorname{Ma}(2 \mathrm{~s}, \operatorname{MSWD}=2.0, \mathrm{n}=9$; Figura 12I).

\section{Discusión}

4.1. Edad del magmatismo permo-triásico y geocronología $\mathrm{U}-\mathrm{Pb}$ en zircón

El magmatismo permo-triásico del NW de Sonora se encuentra representado por un conjunto de granitoides con edades de cristalización U-Pb en zircón en un rango aproximado de 284-221 Ma (Figura 13). Este rango indica un intervalo de actividad magmática de aproximadamente $60 \mathrm{Ma}$, sugiriendo el inicio del arco continental en el Pérmico temprano hasta el Triásico tardío. Las rocas afloran en diversas localidades del NW de Sonora como en el área de estudio de la Sierra Los Tanques (este estudio; R. García-Flores, com. pers., 2015), Sierra Pinta (Arvizu et al., 2009a), Sierra San Francisco (Velázquez-Santelíz, 2014), Sierra Enterrada (Paz-Moreno, com. pers., 2011) y Sierra Blanca (Paz-Moreno, com. pers., 2011) (Figura 1). Cabe señalar que la mayoría de estas rocas permo-triásicas distribuidas en las zonas antes mencionadas estaban cartografiadas como de edad proterozoica o incluso como rocas del Cretácico tardío o del Paleógeno-Neógeno (e.g., SGM, 2002). En el histograma de la Figura 14 se muestra una distribución de los datos geocronológicos existentes del magmatismo presente en el NW de Sonora, además del tipo de tectonismo dominante desde el Proterozoico hasta el Cenozoico. A grandes rasgos, se observa que en el NW de Sonora existen diversos pulsos y gaps magmáticos representados por ausencia de magmatismo y por rocas ígneas con características calcialcalinas asociadas a
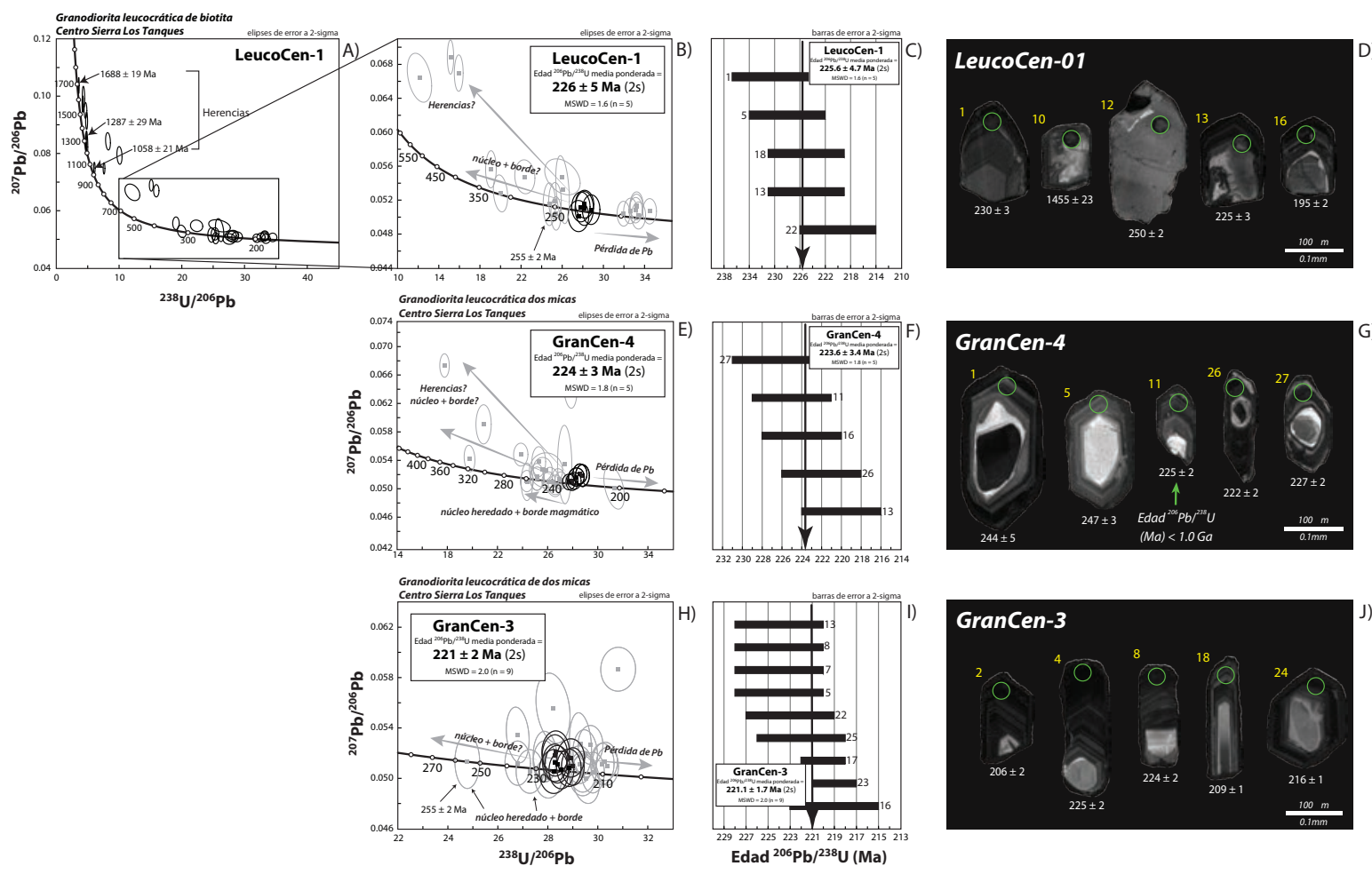

Figura 12. Datos analíticos de U-Pb obtenidos de zircones de granitoides pérmicos de Sierra Los Tanques utilizando la técnica de ablación láser (LAICP-MS). (A), (E) e (H) Gráficos de concordia tipo Tera-Wasserburg mostrando todos los datos de los zircones analizados de las muestras LeucoCen-1, GranCen-4 y GranCen-3. (B) y (E) Acercamientos a los datos más jóvenes en donde se muestra la edad ${ }^{206} \mathrm{~Pb} /{ }^{238} \mathrm{U}$ media ponderada calculada para cada muestra. Los análisis representados por las elipses y cuadrados de color negro fueron empleados para el cálculo de la edad media ponderada, mientras que los análisis en color gris (elipses y cuadrados) fueron descartados para este cálculo debido a que representan zircones con herencias y/o pérdida de $\mathrm{Pb}$. (C), (G) y (K) Gráficos de media ponderada mostrando los análisis empleados para calcular la edad media ponderada. (D), (H) y (L) Imágenes de catodoluminiscencia de algunos zircones representativos de cada muestra, mostrando el lugar de ablación y debajo de cada zircón la edad determinada en ese punto del zircón. 
subducción para formar el arco magmático continental cordillerano desde el Pérmico hasta básicamente el Mioceno (e.g., Izaguirre-Pompa, 2006, 2009; Vidal-Solano et al., 2008; Roldán-Quintana et al., 2009; Valencia-Moreno et al., 2011; Arvizu-Gutiérrez, 2012), estableciéndose éste, en un basamento de edad proterozoica y paleozoica y de

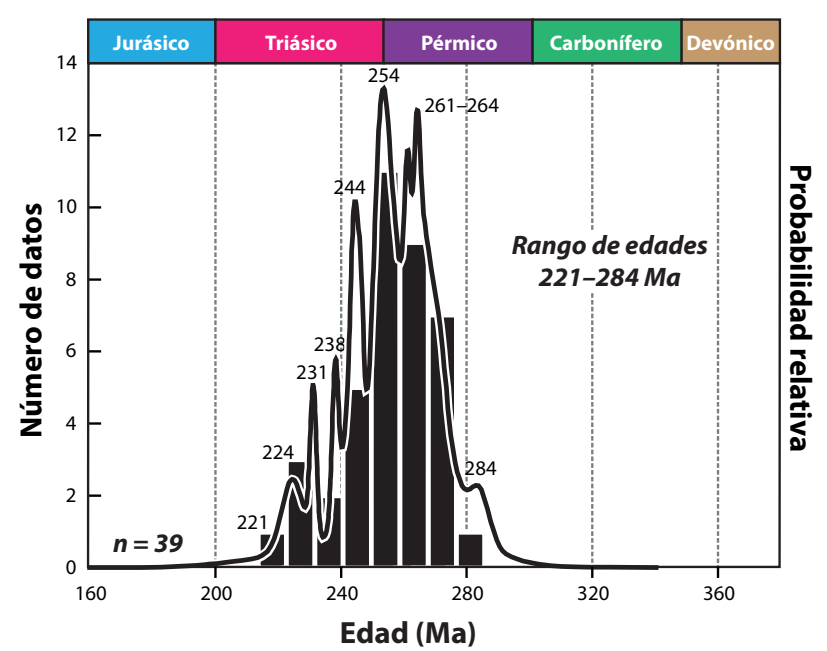

Figura 13. Histograma y diagrama de probabilidad de edades de cristalización U-Pb de zircones de granitoides permo-triásicos del NW de Sonora (datos de este trabajo y referencias mencionadas en el texto). naturaleza totalmente laurenciana (Figura 14) (e.g., Iriondo, 2001; Iriondo et al., 2004; Nourse et al., 2005).

Por otra parte, la mayoría de los análisis de zircón de los granitoides permo-triásicos muestran concentraciones altas de $\mathrm{U}$, sugiriendo que han sufrido diferentes grados de pérdida de $\mathrm{Pb}$. En el caso de los zircones más viejos, estos podrían representar zircones con diferentes grados de herencia en los cuales se muestreó parte de un núcleo o simplemente dominios más viejos del zircón como lo revelan las imágenes de catodoluminiscencia (Figuras 9 $12 \mathrm{D}, \mathrm{H}$ y L).

La presencia de análisis concordantes con edades proterozoicas (Figura 15), que corresponden a núcleos heredados como se muestra en las imágenes de catodoluminiscencia (Figuras 9-12 D, H y L), puede ser fácilmente explicada ya que estas edades son comunes para el basamento granítico meta-ígneo existente en la región de $\sim 1.7-1.6 \mathrm{Ga}, \sim 1.4 \mathrm{y} \sim 1.1 \mathrm{Ga}$ (e.g., Iriondo et al., 2004, 2005; Nourse et al., 2005; Izaguirre et al., 2008; Arvizu et al., 2009b; Iriondo y Premo, 2010), incluso consistentes con las edades proterozoicas obtenidas de rocas de basamento para la zona de estudio de Sierra Los Tanques (Arvizu-Gutiérrez, 2012). En el histograma de la Figura $15 \mathrm{~A}$ se observan las edades individuales U-Pb en zircón obtenidas de todas las muestras fechadas en este estudio, observándose picos significativos a $\sim 238 \mathrm{Ma}$ y $\sim 258 \mathrm{Ma}$

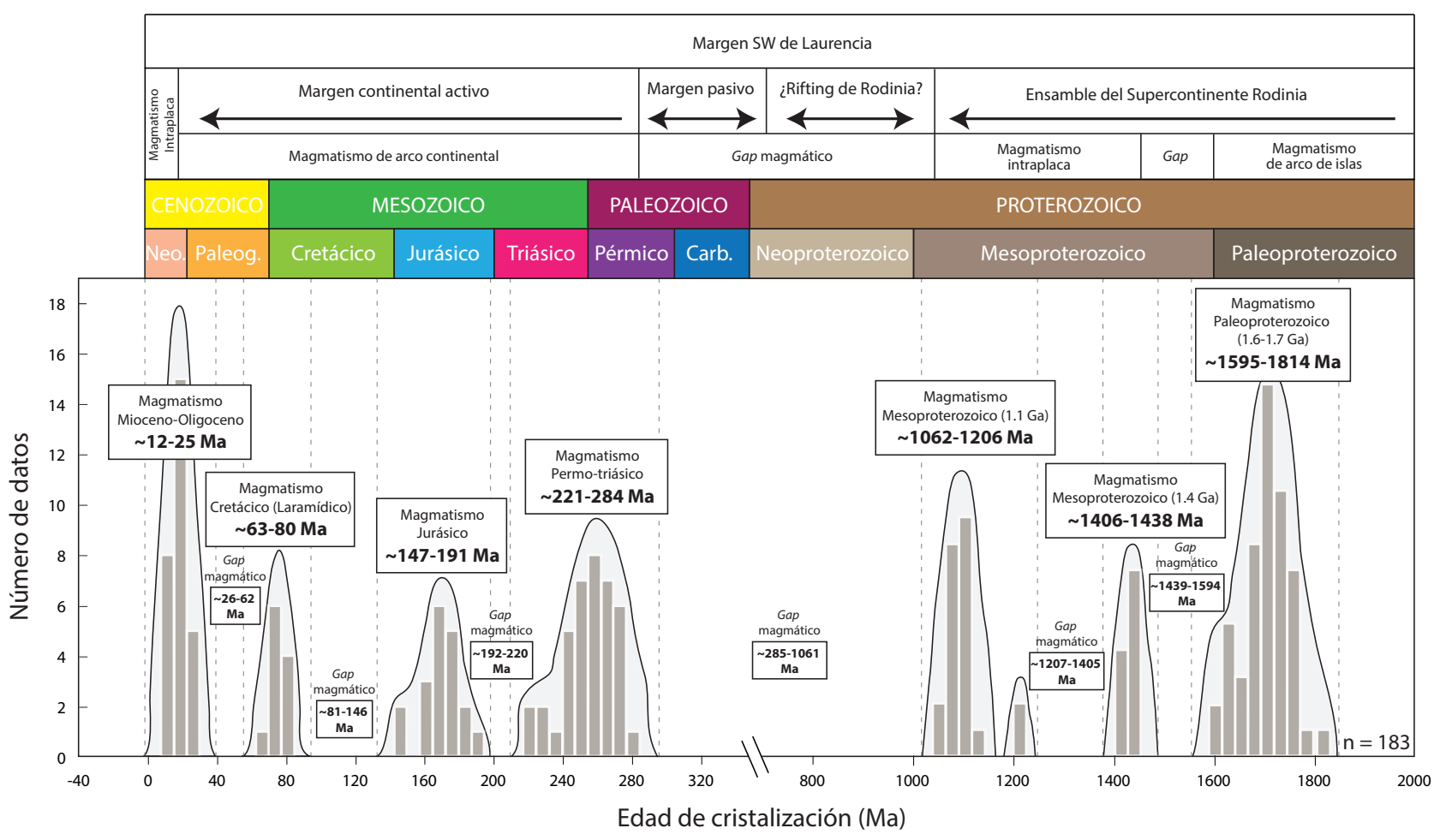

Figura 14. Histograma mostrando los periodos, rangos y gaps de magmatismo en el NW de Sonora empleando principalmente las edades U-Pb de cristalización en zircones de rocas ígneas. También se observa el tipo de tectonismo dominante desde el Proterozoico al Cenozoico relacionado a cada pulso o periodo de magmatismo y ausencia del mismo durante la evolución geológica de la región. La mayor parte de la base de datos utilizada para el desarrollo del histograma se encuentra recopilada en Izaguirre-Pompa (2009) y sus referencias, mientras que el resto son datos generados en ArvizuGutiérrez, 2012 y en este estudio. 


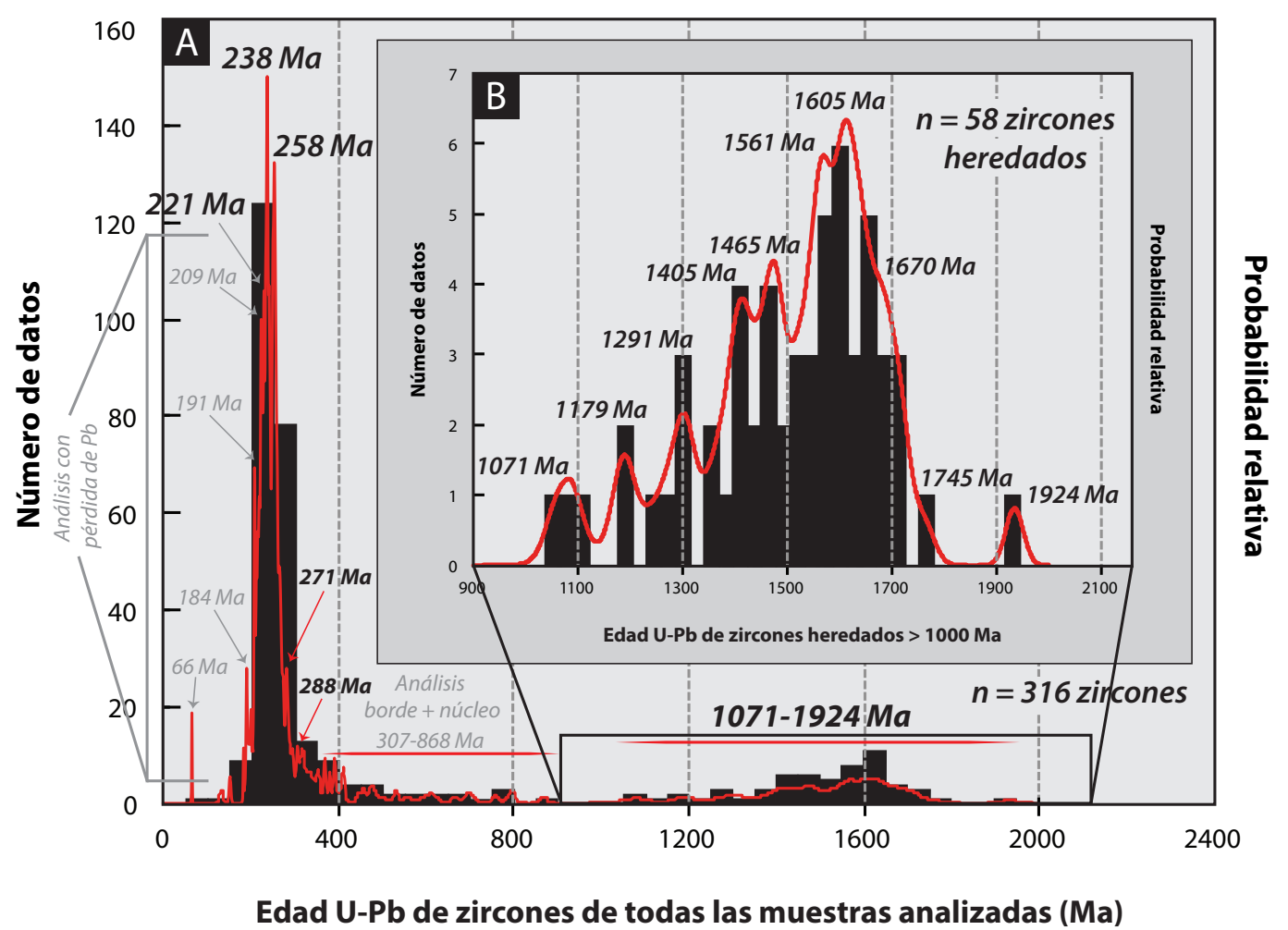

Figura 15. A) Histograma y diagrama de probabilidad de edades $\mathrm{U}-\mathrm{Pb}$ de zircones individuales de todas las muestras de granitoides permo-triásicos fechadas en este trabajo. B) Histograma y diagrama de probabilidad de edades $\mathrm{U}-\mathrm{Pb}$ de zircones heredados fechados en las muestras de granitoides permo-triásicos.

que coinciden con el rango de edades de cristalización (edades $\mathrm{U}-\mathrm{Pb}$ medias ponderadas) determinadas para la mayoría de las rocas datadas en este trabajo. Una interpretación importante que se podría evaluar y que no se puede descartar, es que algunos de los zircones más antiguos de edad pérmica y que son relativamente concordantes, en un rango entre $\sim 258-288 \mathrm{Ma}$, podrían representar las edades de cristalización originales de algunas rocas, pero que posteriormente sufrieron un grado significativo de pérdida de plomo. No obstante, los granitoides permotriásicos contienen abundantes zircones heredados (algunos altamente concordantes; Figuras 9-12 D, H y L) con edades que varían en un rango entre $\sim 1071-1924 \mathrm{Ma}$, con picos o abundancias principales $\mathrm{a} \sim 1.1 \mathrm{Ga}, \sim 1.4 \mathrm{Ga} \mathrm{y} \sim 1.6-1.7$ $\mathrm{Ga}$ (Figura 15B). Se interpreta que estos zircones heredados fueron derivados de la fusión parcial y/o asimilación de las rocas encajonantes de basamento paleoproterozoico presente localmente en Sierra Los Tanques (e.g., bloques, xenolitos, roof pendants).

En los gráficos de $\mathrm{Edad}^{206} \mathrm{~Pb}{ }^{238} \mathrm{U}$ (Ma) vs. Concentración de U (ppm) de la Figuras 16 A - B se observan en (a) todos los análisis de zircón más jóvenes con edades $<300$ Ma y en (b) un acercamiento a los zircones de edad permo-triásica (200 - $300 \mathrm{Ma})$. En ambos gráficos se observa una tendencia al incremento en las concentraciones de $\mathrm{U}$ a medida que el zircón/análisis es más joven. Es importante resaltar que la mayoría de los zircones con edades más jóvenes son zircones con valores altos en $\mathrm{U}(1000-6000 \mathrm{ppm})$ (Figuras 16 A-B, Tabla SE1) que sufrieron pérdida de plomo. De acuerdo a esto, no se descarta que algunos análisis de edades triásicas pudieran haber sido zircones pérmicos con pérdida generalizada de $\mathrm{Pb}$ siguiendo una trayectoria a lo largo de la línea de concordia (Figuras 9-12 D, H y L).

4.2. Relaciones $\mathrm{Th} / \mathrm{U}$ como indicadores del origen de zircones ígneos y metamórficos

Las relaciones $\mathrm{Th} / \mathrm{U}$ se han convertido en un criterio comúnmente empleado para distinguir entre ambientes magmáticos, metamórficos e hidrotermales de formación del zircón (Harley et al., 2007). Incluso, algunos geocronólogos han reconocido por algún tiempo que la relación $\mathrm{Th} / \mathrm{U}$ podría ser usada como un discriminante de primer orden entre zircones magmáticos y metamórficos (e.g., Bibikova, 1984; Pidgeon et al., 2000). Empíricamente, las relaciones $\mathrm{Th} / \mathrm{U}$ de zircones magmáticos tienden a ser $>0.1$ (Vavra et al., 1999; Hoskin e Ireland, 2000; Pidgeon et al., 2000; Belousova et al., 2002; Hidaka et al., 2002), mientras que las relaciones $\mathrm{Th} / \mathrm{U}$ de los zircones metamórficos suelen ser < 0.1 (Hoskin e Ireland, 2000; Hidaka et al., 2002; Rubatto, 2002). Sin embargo, existen muchas situaciones con relaciones $>0.1$ para zircones metamórficos (Vavra et al., 1999; Kröner et al., 2000; Wilde et al., 2001) y <0.1 para zircones magmáticos (Young et al., 1995; Compston, 
1995; Elburg, 1996; Muir et al., 1996; Singh et al., 2002; Lund et al., 2002; Li et al., 2003; Zhai et al., 2005). Las causas de las variaciones de tales relaciones $\mathrm{Th} / \mathrm{U}$ son altamente controversiales (Klötzli, 1999) y su uso ha sido re-evaluado en vista de observaciones texturales y otros criterios químicos (e.g., Möller et al., 2003).

Aunque algunas de las relaciones $\mathrm{Th} / \mathrm{U}$ en los zircones permo-triásicos analizados en este estudio son muy bajas $(<0.1)$ (Figura 16C; Tabla SE1), valores que podrían interpretarse como relaciones típicas para zircones metamórficos, la morfología prismática típica, además de las texturas observadas en las imágenes de catodoluminiscencia indican que la mayoría de los zircones son fácilmente asignados a un origen ígneo, ya que se aprecian zonaciones oscilatorias típicas de crecimiento magmático (Figuras $9-12 \mathrm{D}, \mathrm{H}$ y L). Sin embargo, algunos zircones exhiben texturas o estructuras internas no muy comunes en zircones magmáticos (Figuras $9-12 \mathrm{D}, \mathrm{H}$ y L), quizá producto de recristalización por metamorfismo o disolución por actividad hidrotermal como lo revelan algunas de las relaciones muy bajas de $\mathrm{Th} / \mathrm{U}(\leq 0.02$, Figura $16 \mathrm{C}$; Tabla SE1). Se han documentado que estas relaciones tan bajas de $\mathrm{Th} / \mathrm{U}$ son típicas de zircones que se han formado durante metamorfismo de alto grado (e.g., Williams y Claesson, 1987; Maas et al., 1992; Rubatto, 2002; entre otros) o zircones asociados con interacciones fluido-mineral en estadios tardíos a temperaturas moderadas a altas, durante la cristalización de los zircones (e.g., Vavra et al., 1999; Harley et al., 2001; Carson et al., 2002). Algunos otros zircones no muestran una zonación clara, sino dominios más oscuros ricos en U (Figuras $9-12 \mathrm{D}, \mathrm{H}$ y L) como lo indican las concentraciones altas de este elemento (Tabla SE1).

Las altas variaciones en los contenidos de Th $(\sim 1$ $-1503)$ y $U(\sim 47-9508)$ (Figura 16D; Tabla SE1) en los zircones permo-triásicos analizados también podrían indicar que existe una zonación química dentro de los cristales de zircón como los demuestran las imágenes de catodoluminiscencia. Algunos reportes sobre relaciones
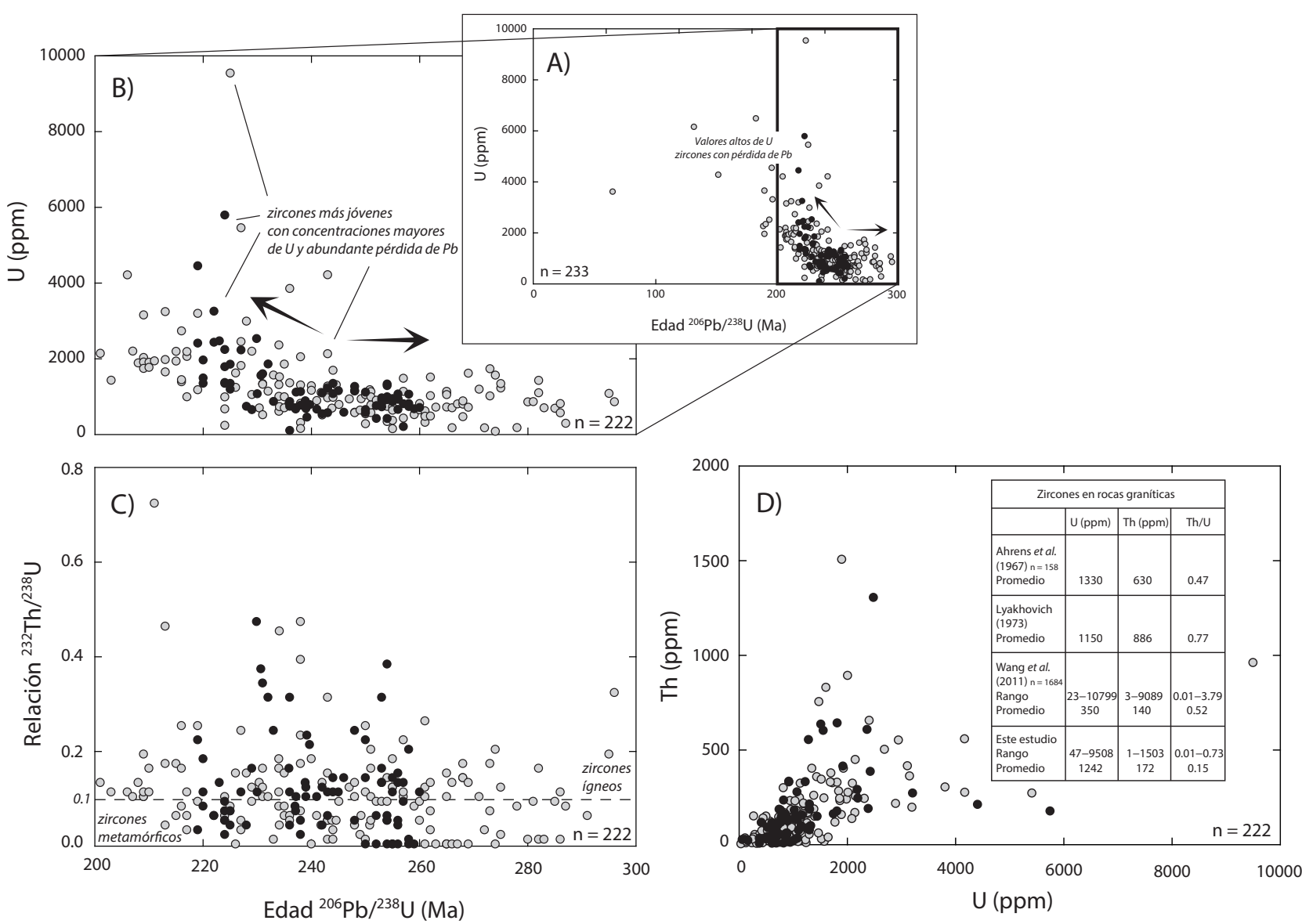

Figura 16. A) Gráfico de Edad ${ }^{206} \mathrm{~Pb} /{ }^{238} \mathrm{U}$ (Ma) vs. Concentración de $\mathrm{U}(\mathrm{ppm})$ de todos los zircones analizados más jóvenes $<300$ Ma utilizando 233 análisis individuales. Los círculos en negro representan los análisis de zircón utilizados para calcular las diferentes edades de las rocas reportadas en este trabajo (ver Tabla 1 y Figuras 9 -12), mientras que los círculos grises son los análisis descartados para el cálculo de la edad por representar zircones con diferentes grados de pérdida de $\mathrm{Pb}$ y/o núcleos heredados. B) Acercamiento mostrando solamente los zircones de edad permo-triásica (222 análisis). C) Gráfico de Edad ${ }^{206} \mathrm{~Pb} /{ }^{238} \mathrm{U}(\mathrm{Ma})$ vs. Relación ${ }^{232} \mathrm{Th} /{ }^{238} \mathrm{U}$. La línea punteada a 0.1 en la relación $\mathrm{Th} / \mathrm{U}$ muestra una tentativa división para el origen de los zircones apoyada de datos de literatura (e.g., Hoskin y Black, 2000; entre otros discutidos en el texto). Los valores $>0.1$ indican un origen ígneo mientras que los valores $<0.1$ indican posiblemente un origen metamórfico para los zircones. D) Gráfico de concentraciones de U (ppm) vs. Th (ppm) de todos los zircones permo-triásicos. 
bajas de Th/U en zircones magmáticos (e.g., Zheng et al., 1999) sugieren que los valores bajos en estas relaciones, determinados en los zircones magmáticos de los granitoides permotriásicos son razonables.

Por ejemplo, las concentraciones de U y Th promedio en zircones graníticos han sido propuestas en 1330 ppm y 630 ppm, respectivamente (Figura 16D; Ahrens et al., 1967). Un resultado similar fue obtenido por Lyakhovich (1973), mostrando promedios de U y Th para zircones graníticos de 1150 ppm y 886 ppm, respectivamente (Figura 16D). Sin embargo, análisis más recientes muestran que los valores de $\mathrm{U}$ y Th en zircones graníticos son mucho menores que los valores aceptados antes mencionados (Wilde y Youssef, 2000; Claesson et al., 2000; Da Silva et al., 2000; Eichhorn et al., 2000; Singh et al., 2002; Lund et al., 2002; Zhou et al., 2002; Li et al., 2002; Thrane, 2002; Li et al., 2003; Liu et al., 2004; Zhai et al., 2005). Inclusive, en un trabajo recientemente publicado por Wang et al. (2011), donde se hace una compilación de datos de literatura, muestra que los contenidos de $\mathrm{U}$ y Th en zircones de rocas graníticas están mejor representados por valores promedio de $350 \mathrm{ppm}$ y 140 ppm, respectivamente (Figura 16D). Aunque, como se mencionó anteriormente, valores mucho más altos de $\mathrm{U}$ y Th (> 1000 ppm para ambos) en zircones magmáticos han sido reportados en la literatura.

El criterio propuesto para distinguir entre zircones magmáticos y metamórficos utilizando las relaciones $\mathrm{Th} / \mathrm{U}$ (e.g., Rubatto, 2002; Hoskin y Schaltegger, 2003) no es infalible de acuerdo a las variaciones considerables de este parámetro marcadas en varios trabajos (e.g., Carson et al., 2002; Kelly y Harley, 2005). Los datos de este estudio apoyan esta conclusión, ya que los zircones permo-triásicos muestran relaciones $\mathrm{Th} / \mathrm{U}$ altamente variables $(0.01-0.73$; Figura 16D), variaciones similares a los valores propuestos para zircones magmáticos y/o metamórficos reportados en literatura (e.g., Ahrens et al., 1967; Lyakhovich, 1973; Wang et al., 2011). Dado este hecho y la evidencia de relaciones variables de $\mathrm{Th} / \mathrm{U}$ descritas anteriormente, los valores de $\mathrm{Th} / \mathrm{U}$ pueden sólo ser usados con precaución y en colaboración con otros criterios químicos para valorar el origen del zircón dentro de su contexto textural como lo podría ser la geoquímica de $R E E$ en el zircón.

4.3. Implicaciones tectónicas del magmatismo permotriásico en el NW de México

El estudio de las rocas paleoproterozoicas del SW de Norteamérica ha permitido caracterizar y proponer una división del basamento paleoproterozoico en el margen continental del SW de Laurencia en tres diferentes provincias: Mojave, Yavapai y Mazatzal (Figura 17A) (e.g., Karlstrom et al., 1987; Karlstrom y Bowring, 1988; Karlstrom y Bowring, 1993; Wooden y Miller, 1990; Iriondo et al., 2004; Iriondo y Premo, 2010 y sus referencias). La presencia de rocas paleoproterozoicas aflorantes en el NW de Sonora, como en las regiones de Quitovac, Cabeza
Prieta-Pinacate, Cerros San Luisito, Cerro Prieto y Zona Canteras-Puerto Peñasco (Iriondo et al., 2004; Nourse et al., 2005; Gutiérrez-Coronado et al., 2008; Izaguirre et al., 2008; Arvizu et al., 2009b) sugiere mediante estudios geocronológicos, geoquímicos e isotópicos que el basamento cristalino en esta región presenta similitudes con rocas asociadas a la provincia Yavapai, por lo que se propone la extensión de estas provincias hacia México (Figuras 17 A y B).

Iriondo $(2005,2007)$ sugiere que la agrupación de rocas paleoproterozoicas con características Yavapai en Sonora, que mantienen una dirección estructural predominantemente NW-SE (Figura 17), han podido actuar como una zona de debilidad cortical (sutura) desde el Paleoproterozoico. Esta debilidad pudo haber condicionado notablemente algunos eventos geológicos subsecuentes presentes en Sonora como la orientación del rifting continental durante la ruptura del supercontinente Rodinia; la ubicación preferencial para el emplazamiento del magmatismo y la formación de cuencas sedimentarias mesozoicas; la canalización de fluidos metamórficos para la formación del cinturón de $\mathrm{Au}$ orogénico laramídico; la ubicación preferencial para el magmatismo terciario, principalmente volcanismo; la orientación de la apertura (rifting) del Golfo de California; y quizá, la presencia de magmatismo máfico cuaternario (e.g., Campos volcánicos del Pinacate y Moctezuma) a lo largo de la franja de corteza Yavapai.

Algunos autores (e.g., Arvizu et al., 2009a; 2009b; Iriondo y Premo, 2010) sugieren que esta zona representada por la franja de Yavapai mexicano (Figura 17) también sirvió para que los primeros magmas asociados a la subducción permo-triásica y al inicio del arco magmático continental cordillerano del SW de Norteamérica ascendieran hacia la superficie con mayor facilidad (Figura 17B). Esto a través de una corteza continental comparativamente fría después de cientos de millones de años como corteza de margen continental pasiva generada posteriormente al rifting o ruptura del supercontinente Rodinia en el Neoproterozoico y/o Paleozoico Inferior (Stewart, 1976, 1988; Li et al., 2008) (Figura 14).

Cabe aclarar que lo que se considera como zona de debilidad cortical Yavapai es sólo una hipótesis para explicar el conducto por el cual los magmas generados por subducción durante el permo-triásico ascendieron hacia la superficie. Sin embargo, aún no se puede demostrar pero estudios recientes antes mencionados indican que esta hipótesis podría ser factible para explicar la presencia de las rocas ígneas permo-triásicas en el NW de Sonora como en las localidades de Sierra Enterrada, Sierra Blanca, Sierra San Francisco, Sierra Los Tanques y Sierra Pinta (Figura 17B).

4.4. Relación entre el magmatismo permo-triásico en el NW de Sonora y el magmatismo cordillerano del SW de Norteamérica, noreste, centro y sur de México

El descubrimiento del pulso magmático permo-triásico 


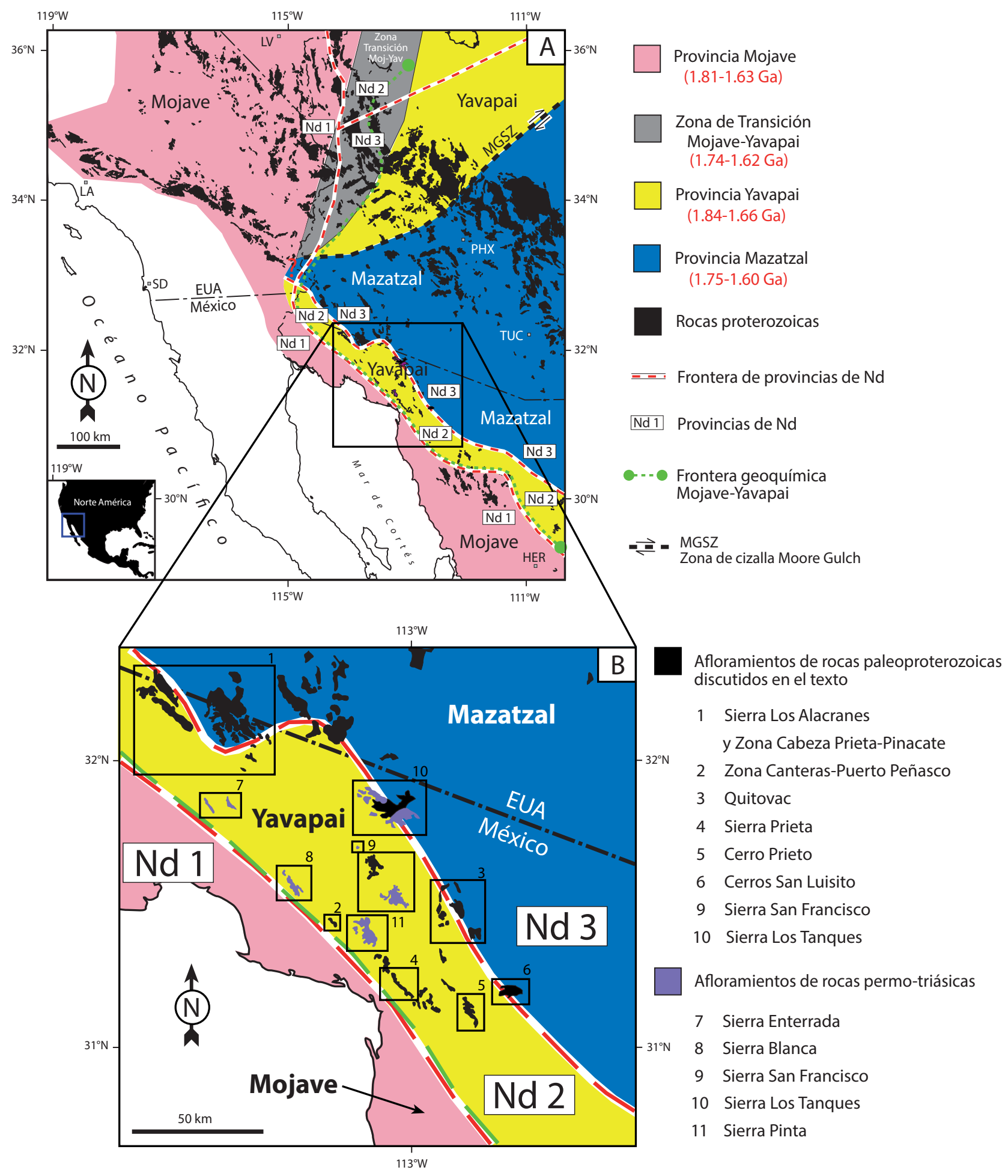

Figura 17. (A) Distribución tentativa de las provincias paleoproterozoicas Mojave, Yavapai y Mazatzal en el SW de Laurencia, incluyendo los afloramientos del NW de México (Iriondo y Premo, 2010). El rango de edades de cristalización (en rojo) para rocas ígneas de cada una de las provincias está basado en la recopilación de edades de Iriondo et al. (2004). También se presenta, de forma tentativa, la extensión de la traza de fronteras de Nd y de las series geoquímicas al internarse en México (Iriondo y Premo, 2010). Las abreviaciones son LA: Los Ángeles, SD: San Diego, LV: Las Vegas, PHX: Phoenix, TUC: Tucson, HER: Hermosillo. (B) Acercamiento al NW de Sonora mostrando los afloramientos de rocas graníticas permo-triásicas encontrados hasta la fecha en la región y que se encuentran espacialmente asociadas a la franja del Yavapai mexicano (este estudio y referencias mencionadas en el texto). 
en el NW de Sonora, con edades U-Pb en zircones entre 284 - $221 \mathrm{Ma}$ (Figura 13) se puede asociar a subducción $\mathrm{y}$ al inicio del arco magmático continental del SW de Norteamérica. Esto contrasta con la idea de que el comienzo de la subducción para formar el arco magmático continental cordillerano en el SW de Norteamérica inició con la intrusión de plutones graníticos de edad básicamente triásica ( 250 - $207 \mathrm{Ma}$; Barth et al., 1997; Barth y Wooden, 2006) emplazados en el basamento paleoproterozoico, como resultado del inicio de la convergencia a lo largo del margen continental paleozoico pre-existente (e.g., Burchfiel y Davis, 1972, 1975, 1981; Kistler y Peterman, 1973; Dickinson, 1981; Burchfiel et al., 1992). De esta manera, esta ocurrencia de magmatismo pérmico en el NW de México permite recorrer varios millones de años hacia atrás (>30 Ma) el inicio de la subducción y el establecimiento del margen continental activo en el SW de Norteamérica.

La ocurrencia de algunos plutones de edad permo-triásica ( $260-207 \mathrm{Ma})$ en los estados de Nevada, California y Arizona (e.g., Snow et al., 1991; Bateman, 1992; Burchfield et al., 1992; Miller et al., 1992, 1995; Dunne y Saleeby, 1993; Schweickert y Lahren, 1993; Barth et al., 1997; Barth y Wooden, 2006) parece estar asociada a dos diferentes procesos de formación. Por un lado, los plutones permotriásicos localizados en la parte norte y centro de California y los del oeste de Nevada, parecen estar asociados a un arco magmático de islas constituido por terrenos oceánicos acrecionados (Figura 18), creado a distancia del margen continental y que posteriormente colisionaron contra el continente en tiempos mesozoicos (Barth et al., 1990, 1997; Busby-Spera et al., 1990; Saleeby y Busby-Spera, 1992; Barth y Wooden, 2006). Asimismo, estos autores plantean que algunos de estos plutones permo-triásicos en la parte sur de California y oeste de Arizona se encuentran asociados a una zona de subducción paralela al margen continental paleozoico pre-existente, como lo sugiere el patrón de orientación NW del plutonismo y volcanismo permo-triásico que corta basamento proterozoico en esas regiones (Figura 18).

Por otro lado, en el noreste, centro y sur de México el arco continental permo-triásico nombrado arco del Este de México (Torres et al., 1999) está relacionado a una zona de subducción con vergencia hacia el este en el margen oeste de Pangea (Torres et al., 1999; Schaaf et al., 2002; Weber et al., 2005, 2007; Ratschbacher et al., 2009) pero es establecido en corteza gondwánica. Algunos trabajos proponen que pudiera extenderse probablemente hasta el noroeste de Sudamérica (e.g., Centeno-García y Keppie, 1999), específicamente en Colombia, ya que también han sido reportadas rocas de estas edades en esa parte de la Cordillera (e.g., Pindell y Dewey, 1982; Pindell, 1985; Case et al., 1990). Sin embargo, algunas rocas graníticas permo-triásicas estudiadas en la parte norte de la Cordillera Central de Colombia se cree que han registrado el evento colisional entre Laurencia y Gondwana, completando el ensamble final de Pangea durante el Pérmico temprano (e.g., Restrepo et al., 1978, 1991; González, 2001; Vinasco et al., 2006). Investigaciones más recientes han comprobado la continuación del arco magmático permo-triásico hacia Sudamérica (e.g., Cochrane et al., 2014; Spikings et al., 2015).

La reconstrucción geotectónica hipotética presentada en este estudio para el Permo-triásico en la parte oeste-centro de Pangea (Figura 18) está basada principalmente en los modelos de Dickinson y Lawton (2001), Elías-Herrera y Ortega-Gutiérrez (2002) y Godínez-Urban et al. (2011). Primeramente, el cierre del océano Rhéico durante el Paleozoico tardío, a lo largo de una zona de subducción con orientación aproximadamente ENE-WSW y con dirección hacia el sur, permitió la colisión final entre el sur de Laurencia y el noroeste de Gondwana creando el cinturón orogénico o sutura Ouachita-Marathon-Sonora para lograr el ensamble final de Pangea (e.g., Poole et al., 2005). Esta zona inicial de subducción con dirección hacia el sur puede incluir el arco volcánico Las Delicias del Misisípico tardío-Pérmico temprano que se extinguió justo antes de la colisión final continente-continente entre Laurencia y Gondwana en el Pérmico temprano (ca. 281 $\mathrm{Ma})$. De este evento se tiene registro de algunas rocas ígneas de composición dacítica y granítica del arco Las Delicias que están expuestas localmente dentro del bloque Coahuila (López, 1997). Aunque la secuencia expuesta en Las Delicias es interpretada como de tras-arco, por la presencia de wild-flysch, tiene un alcance estratigráfico hasta el Pérmico tardío (McKee et al., 1988). También se han reconocido rocas meta-volcánicas de edad carbonífera en Yucatán cortadas por algunos pozos de exploración petrolera (Marton y Buffler, 1994). Estas rocas, evidentemente, representan la existencia de un arco magmático de edad carbonífera formado previo a la sutura Ouachita-MarathonSonora (e.g., Viele y Thomas, 1989; Marton y Buffler, 1994; López, 1997; Stewart et al., 1999).

Estudios más recientes documentan magmatismo del Pensilvánico temprano en los Altos Cuchumatanes en Guatemala (312 - 317 Ma, Solari et al., 2009) debido a la convergencia oblicua entre Laurencia y Gondwana causada por el desarrollo de una zona de subducción. En este sentido, en el Macizo de Chiapas se han interpretado protolitos de anatexitas del Pérmico temprano $(\sim 272 \mathrm{Ma}$, Weber et al., 2007).

En la reconstrucción geotectónica durante el Permotriásico (Figura 18), las posiciones o paleogeografías de los diferentes bloques corticales que conforman México en la actualidad son inferidas, aunque la posición más probable para estos era que el Bloque Del Sur (DSB), conformado por los Complejos Acatlán (Ac) y Oaxaca (Oax), estaba junto a los Andes Colombianos (CA), mientras que el Bloque de Chortís (ChB) se encontraba localizado más hacia el sur. Por su parte, el sur del bloque Maya ( $\mathrm{MCh}=$ Macizo de Chiapas) durante ese tiempo estaba localizado al noroeste del margen de Gondwana, encontrándose, hacia el este, junto al terreno Mérida (M) (Andes Paleozoicos), actualmente Venezuela 
(Alemán y Ramos, 2000 y sus referencias) mientras que al oeste colindaba con el Bloque Tampico. Los Bloques de Yucatán-Chiapas, Coahuila-Delicias y El Fuerte, de afinidad gondwánica, estaban localizados más hacia el norte cerca de la sutura Ouachita-Marathon-Sonora.

Durante la última etapa de la colisión, en el Pérmico temprano, la parte oeste de Pangea experimentó una convergencia con orientación aproximadamente este-oeste generando una nueva zona de subducción con orientación general NW-SE hacia el este consumiendo una placa oceánica (¿Mezcalera?) y permitiendo el establecimiento del arco magmático continental del Este de México (Figura 18). Todas las unidades de basamento precámbrico y paleozoico de México y Centroamérica antes mencionadas estuvieron

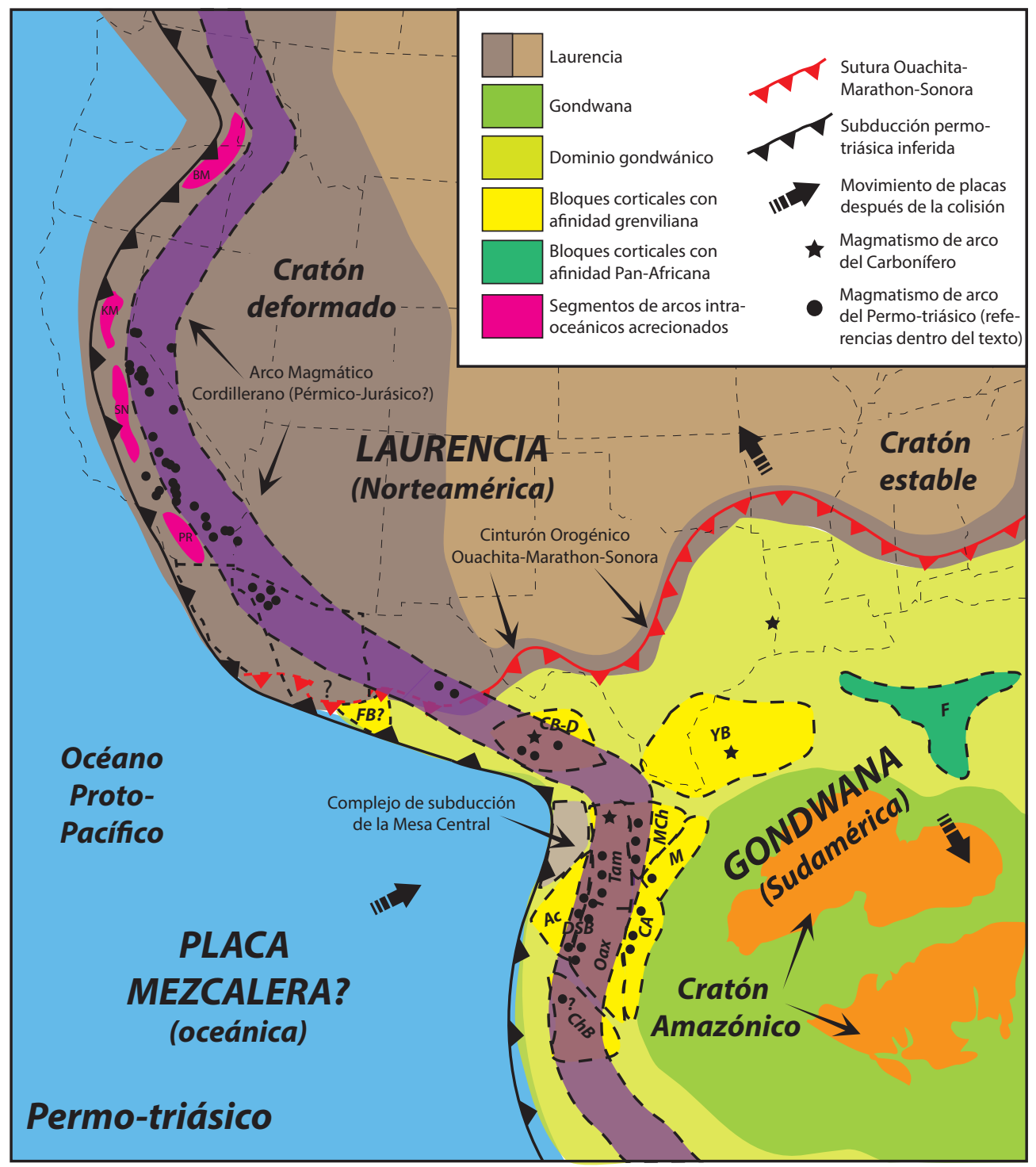

Figura 18. Reconstrucción geotectónica hipotética del Permo-triásico del oeste de Pangea. Se muestra la sutura orogénica Ouachita-Marathon-Sonora propuesta por Poole et al. (2005), la cual se infiere se extiende hacia Sonora. Las posiciones o paleogeografías de los diferentes bloques corticales que conforman México en la actualidad son inferidas (modificadas a partir de Dickinson y Lawton, 2001; Elías-Herrera y Ortega-Gutiérrez, 2002; entre otros). En este mapa también se muestra la posición inferida del arco cordillerano continental Pérmico-Jurásico? y la zona de subducción (según Dickinson y Lawton, 2001; Dickinson, 2006; Godínez-Urban et al., 2011). La localización de los segmentos de arco intraoceánicos acrecionados en EUA son según Dickinson (2006), en donde BM = Blue Mountains, $\mathrm{KM}=$ Klamath Mountains, $\mathrm{SN}=$ Sierra Nevada y PR = Peninsular Ranges. También se muestran las principales localidades de rocas volcánicas-plutónicas de edad permo-triásica que forman parte del inicio del arco magmático cordillerano instaurado en el borde oeste de Pangea (Torres et al., 1999). Los afloramientos permo-triásicos no están a escala. Los círculos negros, como se muestra en la leyenda, representan la ubicación de algunas localidades con los principales cuerpos ígneos de edad permo-triásica reportados hasta la fecha en publicaciones científicas. Las localidades de estas rocas ígneas permo-triásicas se encuentran discutidas en el texto. Las estrellas en color negro representan magmatismo de arco de edad carbonífera generado previo a la fase final de colisión entre Laurencia y Gondwana creando la sutura orogénica en el Pérmico temprano (ca. $281 \mathrm{Ma}$ ). En línea punteada delgada se presenta la configuración geográfica actual de Norteamérica. Abreviaturas = Ac: Complejo Acatlán, CA: Andes Colombianos, ChB: Bloque de Chortís, CB-D: Bloque Coahuila-Delicias, DSB: Bloque Del Sur (Ac+Oax), F: Florida, FB: Bloque El Fuerte, M: Terreno Mérida, MCh: Macizo de Chiapas, Oax: Complejo Oaxaca, Tam: Bloque Tampico, YB: Bloque Yucatán-Chiapas. 
involucradas dentro de este complejo de subducción (ElíasHerrera y Ortega-Gutiérrez, 2002). Se propone que el arco del Este de México se instauró inicialmente a lo largo del Bloque Tampico marcando un arreglo linear norte-sur (Torres et al., 1999), extendiéndose hacia el sur dentro del Bloque del Sur (Sedlock et al., 1993). Dickinson y Lawton (2001) especularon que el magmatismo pre-jurásico del Bloque de Chortís (Donnelly et al., 1990) podría incluir rocas plutónicas que representarían una extensión hacia el sur del arco permo-triásico del Este de México. Estudios recientes han corroborado esa hipótesis (e.g., Cochrane et al., 2014; Spikings et al., 2015). Posteriormente, el magmatismo cruzó el Macizo de Chiapas, parte del Bloque Yucatán-Chiapas, continuando hacia el norte como un cinturón arqueado de plutones aislados emplazados dentro del Bloque Coahuila-Delicias (Salvador, 1991; Sedlock et al., 1993; López, 1997) y en menor proporción, dentro de corteza Laurenciana, al norte de la sutura OuachitaMarathon-Sonora, en el estado de Chihuahua (Torres et al., 1999) (Figura 18).

Por su parte, el complejo de subducción de la Mesa Central es un ensamble de depósitos volcanoclásticos, algunos metamorfoseados. Algunos autores le han asignado una edad del Pérmico Inferior (Gursky y Michalzik, 1989; Stewart et al., 1999), pero también se considera una edad triásica basada en zircones detríticos (Barboza-Gudiño et al., 2010). Rocas de este complejo están expuestas al oeste del cinturón plutónico (Figura 18), localizado en "Oaxaquia" (término utilizado para nombrar al ensamble cortical, de afinidad gondwánica, de los Bloques Tampico [Tam] y Bloque Del Sur; Keppie y Ortega-Gutiérrez, 1995; Ortega-Gutiérrez et al., 1995). Otras secuencias, como la Formación Guacamaya de la Sierra Madre Oriental, han sido interpretadas por Dickinson y Lawton (2001) como depósitos de una cuenca antearco asociada con el arco del Este de México. El esquisto Granjeno que incluye rocas serpentinizadas y localmente expuesto en el anticlinorio Huizachal, cerca del borde oeste del Bloque Tampico, podría representar una exposición local del complejo de subducción relacionado con el arco del este de México (Sedlock et al., 1993), ya que ha proporcionado edades del Pérmico tardío (Carrillo-Bravo, 1961).

En conclusión, la ocurrencia de rocas graníticas permotriásicas en el NW de Sonora nos permite enlazar este evento magmático a nivel cordillerano desde el SW de los Estados Unidos (Nevada-California-Arizona), a través de Sonora, hasta Chihuahua, Coahuila, Puebla, Oaxaca y Chiapas en el norte, centro y sur de México (Torres et al., 1999; Centeno-García y Keppie, 1999; Dickinson y Lawton, 2001; Solari et al., 2001; Weber et al., 2007). Se propone una conexión entre el arco magmático permo-triásico del SW de EUA (e.g., Damon et al., 1981; Barth et al., 1997; Barth y Wooden, 2006) y NW de Sonora (Arvizu et al., 2009a) con el arco triásico del Este de México (Torres et al., 1999) y el arco permo-triásico del sur de México (Torres et al., 1999; Solari et al., 2001; Dickinson y Lawton
2001; Weber et al., 2005, 2007; Kirsch et al., 2012; OrtegaObregón et al., 2013) enlazando este evento magmático a nivel cordillerano hasta el noroeste de Sudamérica (e.g., Vinasco et al., 2006; Cardona et al., 2010; Spikings et al., 2015). Al igual que otros autores, esto nos lleva a la conclusión de que este cinturón magmático es el resultado de la subducción permo-triásica a lo largo de un margen continental activo establecido después del ensamble final o sutura de Pangea durante la orogenia Ouachita-MarathonSonora en el Carbonífero tardío-Pérmico temprano (e.g., Ross, 1986; Torres et al., 1999; Dickinson y Lawton, 2001; Poole et al., 2005) formada por el cierre diacrónico de una cuenca oceánica (i.e., océano Rhéico) entre Laurencia y Gondwana, permitiendo su posterior colisión (Graham et al., 1975; Ross, 1979; Viele y Thomas, 1989; Hatcher, 2002).

Iriondo y Arvizu (2009) plantearon como hipótesis que el magmatismo pérmico comenzó inicialmente en la parte sur de México, donde existían las rocas ígneas más antiguas, y avanzó hacia el norte pasando a través del NW de Sonora y siguiendo el camino a California y Nevada en el SW de EUA, en donde el magmatismo, aparentemente, era más joven. Sin embargo, cabe señalar que nuevas ocurrencias de rocas graníticas en el NW de Sonora (Arvizu et al., 2009a; este estudio y sus referencias) han resultado ser tan antiguas como las del sur de México $(\sim 284-250 \mathrm{Ma})$ y tan jóvenes como las del arco del SW de EUA $(\sim 250-$ $221 \mathrm{Ma}$ ) descartándose esa idea inicial de la migración del magmatismo. De cualquier manera, este arco magmático continental permo-triásico representa un gran evento a nivel cordillerano en el SW de Norteamérica que difiere en tiempo y que es básicamente oblicuo al arco Las Delicias más viejo encontrado en el NE de México (e.g., Iriondo y Arvizu, 2009).

La hipótesis de la migración del magmatismo permotriásico del sur y centro de México (instaurado dentro de corteza gondwánica) hacia el norte de México y suroeste de Estados Unidos (establecido dentro de corteza laurenciana) claramente ha sido descartada por la existencia de actividad magmática relacionada a subducción, tanto de edad pérmica como de edad triásica en ambas regiones. Incluso a lo largo de todo el margen oeste de Gondwana desde Norteamérica hasta Perú (e.g., Ratschbacher et al., 2009; Cochrane et al., 2014; Spikings et al., 2015).

El modelo más factible para explicar tal coexistencia de edades, tanto en el noroeste de Sonora-suroeste de Estados Unidos (Laurencia) como en el centro-sur de México (Gondwana), lo explica claramente la existencia de un arco continental activo desde el Pérmico temprano al Triásico tardío. El cual podría haber experimentado variaciones periódicas, a lo largo de ca. $60 \mathrm{Ma}(284-221$ Ma), en el ángulo de subducción (e.g., tectonic switching: Collins, 2002), sugiriendo que la variación entre una subducción plana, superficial o poco profunda (flatslab subduction) y una abrupta (steep-slab subduction) fue espacialmente diacrónica a lo largo del margen cordillerano de Norteamérica. Además, otro factor 
importante que pudo haber influido fue la geometría de la placa subducida (Mezcalera?), la cual también pudo haber variado espacialmente a lo largo del margen continental cordillerano. Todos estos factores han sido documentados en la mayoría de las tectónicas acrecionales y sistema de arcos magmáticos modernos tales como Los Andes (e.g., Gutscher et al., 2000; Ramos y Folguera, 2008).

\section{Conclusiones}

El descubrimiento del magmatismo permo-triásico en el NW de Sonora, no reconocido anteriormente en la región, se encuentra representado por la ocurrencia de un conjunto de granitoides con edades de cristalización U-Pb en zircón en un rango de 284 - 221 Ma. Este rango indica un intervalo de actividad magmática de aproximadamente $60 \mathrm{Ma}$, sugiriendo el inicio del arco continental cordillerano en el margen SW de Laurencia en el Pérmico temprano hasta el Triásico tardío.

La mayoría de los análisis de zircón de los granitoides permo-triásicos muestran concentraciones altas de $\mathrm{U}$, sugiriendo que han experimentado pérdida de $\mathrm{Pb}$ asociada a los eventos magmáticos posteriores a su emplazamiento presentes en la región de estudio. En el caso de los zircones más viejos, estos representan zircones heredados con edades proterozoicas comunes para el basamento metaígneo existente en la región de $\sim 1.7-1.6 \mathrm{Ga}, \sim 1.4 \mathrm{y} \sim$ $1.1 \mathrm{Ga}$. Claramente estas herencias fueron derivadas de la fusión parcial y/o asimilación de las rocas encajonantes de basamento paleoproterozoico presente localmente en Sierra Los Tanques, lo cual se confirma con las edades proterozoicas obtenidas en estudios recientes de rocas de basamento para la zona de estudio.

Las relaciones bajas de $\mathrm{Th} / \mathrm{U}$ de los zircones podrían interpretarse como relaciones típicas para zircones metamórficos, pero la morfología prismática típica, además de las texturas internas observadas en las imágenes de catodoluminiscencia indican que la mayoría de los zircones son de origen ígneo con zonaciones oscilatorias típicas de crecimiento magmático.

La ocurrencia del pulso magmático permo-triásico se asocia regionalmente a una zona de debilidad cortical relacionada al basamento paleoproterozoico del Yavapai mexicano en el NW de Sonora. Por lo tanto, su entendimiento es importante para contribuir en el conocimiento de la evolución tectónica del SW de Norteamérica, ya que representa una fuente regional de zircones detríticos (207 - $292 \mathrm{Ma}$ ) no reconocida anteriormente para cuencas sedimentarias mesozoicas y cenozoicas en Sonora y sur de Arizona. Su existencia también permite enlazar este evento magmático a nivel cordillerano desde el SW de los Estados Unidos pasando por Sonora en el norte, a través del centro y sur de México, hasta el norte de Sudamérica.

Este cinturón magmático es el resultado de la subducción permo-triásica hacia el este y su existencia representa el inicio del magmatismo cordillerano en el SW de Laurencia establecido a lo largo del borde oeste de Pangea inmediatamente después de culminar su ensamble final. El modelo más factible para explicar la coexistencia de rocas con edades permo-triásicas, tanto en Laurencia como en Gondwana, lo explica claramente la existencia de un arco continental activo inicialmente en el Pérmico temprano hasta el Triásico tardío, experimentando variaciones periódicas en el ángulo de subducción, a lo largo de ca. 60 Ma (284 - $221 \mathrm{Ma})$.

\section{Agradecimientos}

Harim Arvizu agradece a las instituciones que otorgaron los proyectos de investigación PAPIIT/UNAM (clave IN116709) y CONACYT (claves CB-82518 y CB-129370), a Alexander Iriondo, por el financiamiento proporcionado para realizar trabajo de campo y estudios de laboratorio. Al CONACYT por la beca otorgada durante la maestría. Agradecimiento especial al compañero y colega Aldo Izaguirre Pompa por el apoyo brindado en las campañas geológicas realizadas en Sierra Los Tanques, NW de Sonora. Se agradece a Luis M. Martínez Torres (Koldo) por el valioso apoyo en campo y valiosa aportación en la cartografía geológica de Sierra Los Tanques. A Luigi Solari, profesor-investigador, y a Carlos Ortega Obregón, técnico del LEI (Laboratorio de Estudios Isotópicos), ambos del CGEO, por la valiosa ayuda y apoyo durante los fechamientos U-Pb en zircones, en lo que respecta a la adquisición de los datos y reducción de los mismos. Se agradece a Luigi Solari por el apoyo ofrecido para obtener imágenes de luz reflejada y transmitida de los zircones. Agradecimiento enorme a Dan Miggins y Heather Lowers del U.S. Geological Survey de Denver por la asistencia en la obtención de imágenes de SEM-Catodoluminiscencia para realizar los estudios de geocronología U-Pb en zircones. Finalmente, Arvizu agradece y aprecia los comentarios, sugerencias y críticas constructivas realizadas por los revisores Bodo Weber y Peter Schaaf, las cuales mejoraron el manuscrito y, de igual manera, a los editores del BSGM por el apoyo logístico brindado para publicar este artículo.

\section{Referencias}

Ahrens, L.H., Cherry, R.D., Erlank, A.J., 1967, Observations on the Th-U relationship in zircons from granite rocks and from kimberlites: Geochimica et Cosmochimca Acta, 31, 2379-2387.

Alemán, A., Ramos, V.A., 2000, Northern Andes, in $31^{\text {st }}$ International Geological Congress: Rio de Janeiro, Cordani, U.G., Milani, E.J., Thomas-Filho, A., Campos, D.A. (eds.), Tectonic evolution of South America, ${ }^{\text {st }}$ International Geological Congress, 453-480.

Anderson, J.L., Cullers, R.L., 1999, Paleo-and Mesoproterozoic granite plutonism of Colorado and Wyoming: Rocky Mountain Geology Fall, 34(2), 149-164.

Anderson, T.H., Silver, L.T., 1979, The role of the Mojave-Sonora megashear in the tectonic evolution of northern Sonora, in Anderson, 
T.H., Roldán-Quintana, J. (eds.), Geology of northern Sonora: Geological Society of America Field Trip Guidebook, 7, 59-68.

Anderson, T.H., Silver, L.T., 2005, The Mojave-Sonora megashear-Field and analytical studies leading to the conception and evolution of the hypothesis, in Anderson, T.H., Nourse, J.A., McKee, J.W., Steiner, M.B. (eds.), The Mojave-Sonora megashear hypothesis: Development, assessment, and alternatives: Geological Society of America Special Paper 393, 1-50.

Arvizu-Gutiérrez, H.E., 2012, Magmatismo permo-triásico en el NW de Sonora, México: Inicio de la subducción y maduración de un margen continental activo: Querétaro, México, Universidad Nacional Autónoma de México, Centro de Geociencias, Campus Juriquilla, Tesis de Maestría, $250 \mathrm{p}$.

Arvizu, H., Iriondo, A., 2011, Estudios isotópicos de Hf en zircones de granitoides pérmicos en el NW de México: Posible evidencia de mezcla de magmas generados a partir de la fusión de múltiples fuentes corticales: Revista Mexicana de Ciencias Geológicas, 28(3), 493-518.

Arvizu, H., Iriondo, A., Izaguirre, A., Chávez-Cabello, G., Kamenov, G.D., Solís-Pichardo, G., Foster, D.A., Lozano-Santa Cruz, R., 2009a, Rocas graníticas pérmicas en la Sierra Pinta en el NW de Sonora, México: Magmatismo de subducción asociado al inicio del margen continental activo del SW de Norte América: Revista Mexicana de Ciencias Geológicas, 26(3), 709-728.

Arvizu, H., Iriondo, A., Izaguirre, A., Chávez-Cabello, G., Kamenov, G.D., Foster, D.A., Lozano-Santa Cruz, R., Solís-Pichardo, G., 2009b, Gneises bandeados paleoproterozoicos $(\sim 1.76-1.73 \mathrm{Ga})$ de la Zona Canteras-Puerto Peñasco: Una nueva ocurrencia de rocas de basamento tipo Yavapai en el NW de Sonora, México: Boletín de la Sociedad Geológica Mexicana, 61(3), 375-402.

Barboza-Gudiño, J.R., Zavala-Monsiváis, A., Venegas-Rodríguez, G., Barajas-Nigoche, L.D., 2010, Late Triassic stratigraphy and facies from northeastern Mexico-Tectonic setting and provenance: Geosphere, 6(5), 621-640.

Barth, A.P., Wooden, J.L., 2006, Timing of magmatism following initial convergence at a passive margin, southwestern U.S. Cordillera, and ages of lower crustal magma sources: The Journal of Geology, $114,231-245$.

Barth, A.P., Tosdal, R.M., Wooden, J.L., 1990, A petrologic comparison of Triassic plutonism in the San Gabriel and Mule Mountains, southern California: Journal of Geophysical Research, 95, 20075-20096.

Barth, A.P., Tosdal, R.M., Wooden, J.L., Howard, K.A., 1997, Triassic plutonism in Southern California; southward younging of arc initiation along a truncated continental margin: Tectonics, 6, 290304.

Bateman, P.C., 1992, Plutonism in the central part of the Sierra Nevada batholith, California: U.S.A, U.S. Geological Survey Professional Paper 1483, $186 \mathrm{p}$.

Belousova, E.A., Griffin, W.L., O'Reilly, S.Y., Fisher, N.I., 2002, Igneous zircon: trace element composition as an indicator of source rock type: Contributions to Mineralogy and Petrology, 143, 602-622.

Bibikova, E.V., 1984, The most ancient rocks in the USSR territory by U-Pb data accessory zircons, in Kröner, A., Hanson, G.N., Goodwin, A.M. (eds.), Archean Geochemistry, Heidelberg: Springer Verlag, 235-250.

Burchfiel, B.C., Davis, G.A., 1972, Structural framework and evolution of the southern part of the Cordilleran orogen, western United States: American Journal of Science, 272, 97-118.

Burchfiel, B.C., Davis, G.A., 1975, Nature and controls of Cordilleran orogenesis, western United States: Extensions of and earlier synthesis: American Journal of Science, 275A, 363-396.

Burchfiel, B.C., Davis, G.A., 1981, Mojave Desert and environs, in Ernst, W.G. (ed.), The geotectonic development of California: Englewood Cliffs, NJ, Prentice-Hall, 217-252.

Burchfiel, B.C., Cowan, D.S., Davis, G.A., 1992, Tectonic overview of the Cordilleran orogen in the western United States, in Burchfiel, B.C., Lipman, P.W., Zoback, M.L. (eds.), The Cordilleran orogen: conterminous U.S. (Geology of North America): Boulder, Colorado, Geological Society of America, G-3, 407-479.
Busby-Spera, C.J., Mattinson, J.M., Riggs, N.R., Schermer, E.R., 1990, The Triassic-Jurassic magmatic arc in the Mojave-Sonoran Deserts and the Sierran-Klamath region: Similarities and differences in paleogeographic evolution, in Harwood, D.S., Miller, M.M. (eds.), Paleozoic and early Mesozoic paleogeographic relations: Sierra Nevada, Klamath Mountains, and related terranes: Geological Society of America Special Paper 225, 325-337.

Campbell, P.A., Anderson, T.H., 2003, Structure and kinematics along a segment of the Mojave-Sonora megashear: A strike-slip fault that truncates the Jurassic continental magmatic arc of southwestern North America: Tectonics, 22(6), 1-21.

Cardona, A., Valencia, V., Garzón, A., Montes, C., Ojeda, G., Ruiz, J., Weber, M., 2010, Permian to Triassic I to S-type magmatic switch in the northeast Sierra Nevada de Santa Marta and adjacent regions, Colombian Caribbean: tectonic setting and implications within Pangea paleogeography: Journal of South American Earth Sciences, 29, $772-783$.

Carrillo-Bravo, J., 1961, Geología del anticlinorio de Huizachal-Peregrina al NW de Ciudad Victoria, Tamaulipas: Boletín de la Asociación Mexicana de Geólogos Petroleros, 8, 1-98.

Carson, C.J., Ague, J.J., Grove, M., Coath, C.D., Harrison, T.M., 2002, $\mathrm{U}-\mathrm{Pb}$ isotopic behaviour of zircon during upper-amphibolite facies fluid infiltration in the Napier Complex, east Antarctica: Earth and Planetary Science Letters, 199, 287-310.

Case, J.E., Shagan, R., Giegengack, R.F., 1990, Geology of the northern Andes: An overview in The Caribbean region: Boulder Colorado, Geological Society of America, The Geology of North America, H, 177-200.

Centeno-García, E., Keppie, J.D., 1999, Latest Paleozoic-Early Mesozoic structures in the central Oaxaca terrane of southern Mexico: Deformation near a triple junction: Tectonopysics, 301, 231-242.

Claesson, S., Vetrin, V., Bayanova, T., Downes, H., 2000, U-Pb zircon age from a Devonian carbonatite dyke, Kola peninsula, Russia; a record of geological evolution from the Archean to the Paleozoic: Lithos, 51, 95-108.

Cochrane, R., Spikings, R., Gerdes, A., Ulianov, A., Mora, A., Villagómez, D., Putlitz, B., Chiaradia, M., 2014, Permo-Triassic anatexis, continental rifting and the disassembly of western Pangaea: Lithos, 190-191, 383-402.

Collins, W.J., 2002, Hot orogens, tectonic switching, and creation of continental crust: Geology, 30(6), 535-538.

Compston, D.M., 1995, Time constraints on the evolution of the Tennant Creek Block, northern Australia: Precambrian Research, 71, 107129.

Damon, P.E., Shafiqullah, M., Clark, K.F., 1981, Age trends of igneous activity in relation to metallogenesis in the Southern Cordillera, in Dickinson, W.R., Payne, W.D. (eds.), Relations of Tectonics to Ore Deposits in Southern Cordillera: Arizona Geological Society Digest, 14, 137-154.

Damon, P.E., Clark, K.F., Shafiqullah, M., 1983, Geochronology of the porphyry copper deposits and related mineralization of Mexico: Canadian Journal of Earth Sciences, 20(6), 1052-1071.

Da Silva, L.C., Gresse, P.G., Scheepers, R., McNaughton, N.J., Hartmann, L.A., Fletcher, I., 2000, U-Pb SHRIMP and Sm-Nd age constraints on the timing and sources of the Pan-African Cape Granite Suite, South Africa: Journal of African Earth Sciences, 30, 795-815.

Dickinson, W.R., 1981, Plate tectonics and the continental margin of California, in Ernst, W.G. (ed.), The geotectonic development of California: Englewood Cliffs, NJ, Prentice-Hall, 1-28.

Dickinson, W.R., 2006, Geotectonic evolution of the Great Basin: Geosphere, 2(7), 353-368.

Dickinson, W.R., Lawton, T.F., 2001, Carboniferous to Cretaceous assembly and fragmentation of Mexico: Geological Society of America Bulletin, 113, 1,142-1,160.

Donnelly, T.W., Horne, G.S., Finch, R.C., López-Ramos, E., 1990, Northern Central America: The Chortis and Maya blocks, in Dengo, G., Case, J.E. (eds.), The Caribbean region: Boulder, Colorado, Geological Society of America, Geology of North America, H, 37-76. 
Dunne, G.C., Saleeby, J.B., 1993, Kern plateau shear zone, southern Sierra Nevada-New data concerning age and northward continuation: Geological Society of America Abstracts with Programs, 25(5), 33.

Eichhorn, R., Loth, G., Holl, R., Finger, F., Schermaier, A., Kennedy, A., 2000, Multistage Variscan magmatism in the central Yauern Window (Austria) unveiled by U/Pb SHRIMP zircon data: Contributions to Mineralogy and Petrology, 139, 418-435.

Elburg, M.A., 1996, U-Pb ages and morphologies of zircon in microgranitoid enclaves and peraluminous host granite: Evidence for magma mingling: Contributions to Mineralogy and Petrology, 123, 177-189.

Elías-Herrera, M., Ortega-Gutiérrez, F., 2002, Caltepec fault zone: An early Permian dextral transpressional boundary between the Proterozoic Oaxacan and Paleozoic Acatlan complexes, southern Mexico, and regional tectonic implications: Tectonics, 21, 1-19.

Godínez-Urban, A., Lawton, T.F., Molina-Garza, R.S., Iriondo, A., Weber, B., López-Martínez, M., 2011, Jurassic volcanic and sedimentary rocks of the La Silla and Todos Santos Formations, Chiapas: Record of Nazas arc magmatism and rift-basin formation prior to opening of the Gulf of Mexico: Geosphere, 7, 121-144.

González, H., 2001, Mapa Geológico del departamento de Antioquia, Escala 1:400000: Medellín, Memoria explicative, Ingeominas.

Goodge, J.W., Vervoort, J.D., 2006, Origin of Mesoproterozoic A-type granites in Laurentia: Hf isotope evidence: Earth and Planetary Science Letters, 243, 711-731.

Graham, S.A., Dickinson, W.R., Ingersoll, R.V., 1975, Himalayan-Bengal model for flysch dispersal in the Appalachian-Ouachita system: Geological Society of America Bulletin, 86, 273-286.

Gursky, H.J., Michalzik, D., 1989, Lower Permian turbidites in the northern Sierra Madre Oriental, Mexico: Zentralblatt für Geologie und Palaöntologie (Teil 1), 1989, 821-838.

Gutiérrez-Coronado, A., Iriondo, A., Rodríguez-Castañeda, J.L., Wooden, J.L., Budahn, J.R., Lozano-Santa Cruz, R., Hernández-Treviño, T., 2008, Paleoproterozoic gneises of the San Luisito Hills in NW Sonora: Extending the Mexican Yavapai province of SW Laurentia: Geological Society of America Abstracts with Programs, 40, 144.

Gutmann, J.T., 1976, Geology of Crater Elegante, Sonora, Mexico: Geological Society of America Bulletin, 87, 1718-1729.

Gutmann, J.T., 1977, Textures and genesis of phenocryst and megacryst in basaltic lavas from the Pinacate volcanic field: American Journal of Science, 277, 833-861.

Gutmann, J.T., 1979, Structure and eruptive cycle of cinder cones in the Pinacate volcanic field and the control of strombolian activity: Journal of Geology, 87, 448-454.

Gutmann, J.T., 1986, Origin of four and five phase ultramafic xenoliths from Sonora, Mexico: American Mineralogy, 71, 1076-1084.

Gutmann, J.T., 2002, Strombolian and effusive activity as precursors to phreatomagmatism: eruptive sequence at maars of the Pinacate volcanic field, Sonora, Mexico: Journal of Volcanology and Geothermal Research, 113, 345-356.

Gutmann, J.T., Turrin B.D., Dohrenwend J.C., 2000, Basaltic rocks from the Pinacate volcanic field yield notably young ${ }^{40} \mathrm{Ar} /{ }^{39} \mathrm{Ar}$ ages: EOS, Transactions American Geophysical Union, 81, 33-37.

Gutscher, M., Spakman, W., Bijwaard, H., Engdahl, E., 2000, Geodynamics of flat subduction: Seismicity and tomographic constraints from the Andean margin: Tectonics, 19, (5), 814-833.

Harley, S.L., Kinny, P.D., Snape, I., Black, L.P., 2001, Zircon chemistry and the definition of events in Archaean granulite terrains, in Cassidy, K.F., Dunphy, J.M., van Kranendonk, M.J. (eds.), Extended Abstracts of $4^{\text {th }}$ International Archaean Symposium: AGSO-Geoscience Australia Record 2001/37, Canberra, 511-513.

Harley, S.L., Kelly, N.M., Möller, A., 2007, Zircon Behaviour and the Thermal Histories of Mountain Chains: Elements, 3, 25-30.

Hatcher, R.D., 2002, Alleghanian (Appalachian) orogeny, a product of zipper tectonics: Rotational transpressive continent-continent collision and closing of ancient oceans along irregular margins, in Martínez-Catalán, J.R., Hatcher, R.D., Arenas, R., Díaz-García, F. (eds.), Variscan-Appalachian dynamics: The building of the Late Paleozoic basement: Geological Society of America Special Paper 364, 199-208.
Haxel, G.B., Tosdal, R.M., May, D.J., Wright, J.E., 1984, Latest Cretaceous and early Tertiary orogenesis in south-central Arizona: Thrust faulting, regional metamorphism, and granitic plutonism: Geological Society of America Bulletin, 95, 631-653.

Hidaka, H., Shimizu, H., Adachi, M., 2002, U-Pb geochronology and REE geochemistry of zircons from Paleoproterozoic paragneiss clasts in the Mesozoic Kamiaso conglomerate, central Japan, Evidence for an Archean provenance: Chemical Geology, 187, 279-293.

Hoskin, P.W.O., Black, L.P., 2000, Metamorphic zircon formation by solid state recrystallization of protolith igneous zircon: Journal of Metamorphic Geology, 18, 423-439.

Hoskin, P.W.O., Ireland, T.R., 2000, Rare earth element chemistry of zircon and its use as a provenance indicator: Geology, 28, 627-630.

Hoskin, P.W.O., Schaltegger, U., 2003, The composition of zircon and igneous and metamorphic petrogenesis, in Hanchar, J.M., Hoskin, P.W.O. (eds.), Zircon: Reviews in Mineralogy and Geochemistry, $53,27-62$.

Iriondo, A., 2001, Proterozoic basements and their Laramide juxtaposition in NW Sonora, Mexico: Tectonic constraints on the SW margin of Laurentia: Boulder, Colorado, University of Colorado, Ph.D. Thesis, $222 \mathrm{p}$.

Iriondo, A., 2005, The Caborca oroclinal bend: A testable hypothesis to explain the NW-SE geological trend of Paleoproterozoic provinces in the Mexican SW Laurentia: GEOS, Unión Geofísica Mexicana, A.C., Resúmenes y Programa, 25(1), 85.

Iriondo, A., 2007, Precambrian geology in NW Mexico: New ideas for the distribution of Paleoproterozoic crustal provinces in SW Laurentia in Symposium Ores \& Orogenesis: Circum-Pacific Tectonics, Geologic Evolution and Ore Deposits: Tucson, Arizona (Abstract 256).

Iriondo, A., Arvizu, H., 2009, Permian ( $275-258 \mathrm{Ma})$ granitic magmatism in NW Sonora, Mexico: The missing link to a large continental arc event in SW North America, in Geological Society of America, South-Central Section, in $43^{\text {rd }}$ Annual Meeting: Dallas, Texas, USA, Geological Society of America, Abstracts with Programs, 41(2), 35.

Iriondo, A., Premo, W.R., 2010, Las rocas cristalinas proterozoicas de Sonora y su importancia para la reconstrucción del margen continental SW de Laurencia-la pieza mexicana del rompecabezas de Rodinia, in Calmus, T. (ed.), Panorama sobre la geología de Sonora, México: Universidad Nacional Autónoma de México, Instituto de Geología, Boletín 118(2), 25-55.

Iriondo, A., Premo, W.R., Martínez-Torres, L.M., Budahn, J.R., Atkinson, W.W., Jr., Siems, D.F., Guarás-González, B., 2004, Isotopic, geochemical and temporal characterization of Proterozoic basement rocks in the Quitovac region, northwestern Sonora, Mexico: Implications for the reconstruction of the southwestern margin of Laurentia: Geological Society of America Bulletin, 116, 154-170.

Iriondo, A., Martínez-Torres, L.M., Kunk, M.J., Atkinson, W.W., Jr., Premo, W.R., McIntosh, W.C., 2005, Northward Laramide thrusting in the Quitovac region, northwestern Sonora, Mexico: Implications for the juxtaposition of Paleoproterozoic basement blocks and the MojaveSonora megashear hypothesis, in Anderson, T.H., Nourse, J.A., McKee, J.W., Steiner, M.B. (eds.), The Mojave-Sonora megashear hypothesis: Development, assessment, and alternatives: Geological Society of America Special Paper 393, 631-669.

Iriondo, A., Kamenov, G.D., Foster, D.A., 2008, The Sierra Los Tanques $1.1 \mathrm{Ga}$ Granite in NW Sonora: Another example of Mesoproterozoic plutonism along the Mexican Yavapai province, in 2008 Joint Meeting, Geological Society of America, eeting, Abstract with Programs, 145, 144.

Izaguirre-Pompa, A., 2006, Estudio petrológico y geocronológico del volcanismo orogénico intermedio-ácido de edad oligo-mioceno del norte de Caborca, Sonora, México: Hermosillo, Sonora, Universidad de Sonora, Departamento de Geología, Tesis de Licenciatura, $94 \mathrm{p}$.

Izaguirre-Pompa, A., 2009, El basamento paleoproterozoico $(\sim 1.71-1.68$ Ga) Yavapai en el área Mina La Herradura en el NW de Sonora: Sus implicaciones para el desarrollo del arco magmático continental Mesozoico-Cenozoico del NW de México: Juriquilla, Querétaro, Universidad Nacional Autónoma de México, Centro de Geociencias, 
Tesis de Maestría, $202 \mathrm{p}$.

Izaguirre, A., Iriondo, A., Wooden, J.L., Budahn, J.R., Schaaf, P., 2008, Paleoproterozoic orthogneisses from the Cerro Prieto area-a new addition to the Mexican Yavapai province in NW Sonora, in Joint Annual Meeting, Geological Society of America Abstracts with Programs, 40(6), 143-144.

Karlstrom, K.E., Bowring, S.A., 1988, Early Proterozoic assembly of tectonostratigraphic terranes in southwestern North America: Journal of Geology, 96, 561-576.

Karlstrom, K.E., Bowring, S.A., 1993, Proterozoic orogenic history of Arizona, in Van Schmus, W.R. (another 24 eds.), Transcontinental Proterozoic provinces, in Reed, J.C., Jr., Bickford, M.E., Houston, R.S., Link, P.K., Rankin, D.W., Sims, P.K., Van Schmus, W.R. (eds.), Precambrian: Conterminous U.S: Geological Society of America, The Geology of North America C-2, 188-211.

Karlstrom, K.E., Bowring, S.A., Conway, C.M., 1987, Tectonic significance of an Early Proterozoic two-province boundary in central Arizona: Geological Society of American Bulletin, 9, 529-538.

Kelly, N.M., Harley, S.L., 2005, An integrated microtextural and chemical approach to zircon geochronology: refining the Archaean history of the Napier Complex, east Antarctica: Contributions to Mineralogy and Petrology, 149, 57-84.

Keppie, J.D., Ortega-Gutiérrez, F., 1995, Provenance of Mexican terranes: Isotopic constraints: International Geology Reviews, 37, 813-824.

Kirsch, M., Keppie, J.D., Murphy, J.B., Solari, L., 2012, PermianCarboniferous arc magmatism basin evolution along the western margin of Pangea: geochemical and geochronological evidence from the eastern Acatlan Complex, southern Mexico: Geological Society of America Bulletin, 124, 1607-1628.

Kistler, R.W., Peterman, Z.E., 1973, Variations in Sr, Rb, K, Na, and initial ${ }^{87} \mathrm{Sr} /{ }^{86} \mathrm{Sr}$ in Mesozoic granitic rocks and intruded wall rocks in central California: Geological Society of America Bulletin, 84, 3489-3512.

Klötzli, U.S., 1999, Th/U zonation in zircon derived from evaporation analysis: A model and its implications: Chemical Geology, 158, 325-333.

Kröner, A., O’Brien, P.J., Nemchin, A.A., Pidgeon, R.T., 2000, Zircon ages for high pressure granulites from South Bohemia, Czech Republic, and their connection to Carboniferous high temperature processes: Contributions to Mineralogy and Petrology, 138, 127-142.

Li, X., Li, Z.X., Zhou, H., Liu, Y., Kinny, P.D., 2002, U-Pb zircon geochronology, geochemistry and $\mathrm{Nd}$ isotopic study of Neoproterozoic bimodal volcanic rocks in the Kangdian Rift of South China; implications for the initial rifting of Rodinia: Precambrian Research, 113, 135-154.

Li, Z.X., Li, X., Kinny, P.D., Wang, J., Zhang, S., Zhou, H., 2003, Geochronology of Neoproterozoic syn-rift magmatism in the Yangtze Craton, South China and correlations with other continents: Evidence for a mantle superplume that broke up Rodinia: Precambrian Research, 122, 85-109.

Li, Z.X., Bogdanova, S.V., Collins, A.S., Davison, A., De Waele, B., Ernst, R.E., Fitzsimons, I.C.W., Fuck, R.A., Gladkochub, D.P., Jacobs, J., Karlstrom, K.E., Lu, S., Natapov, L.M., Pease, V., Pisarevsky, S.A., Thrane, K., Vernikovsky, V., 2008, Assembly, configuration, and break-up history of Rodinia: A synthesis: Precambrian Research, $160,179-210$

Liu, Q., Wu, Z., Hu, D., Ye, P., Jiang, W., Wang, Y., Zhang, H., 2004, SHRIMP U-Pb zircon dating on Nyainqentanglha granite in central Lhasa block: Chinese Science Bulletin, 49, 76-82.

López, R., 1997, High-Mg andesites from the Gila Bend Mountains: Evidence for hydrous melting of the lithosphere during Miocene extension, and the pre-Jurassic geotectonic evolution of the Coahuila terrane, northeastern Mexico: Grenville basement, a late Paleozoic arc, Triassic plutonism, and the events south of the Ouachita suture: Santa Cruz, California, University of California, Ph.D. thesis, 147 p.

Lund, K., Aleinikoff, J.N., Kunk, M.J., Unruth, D.M., Zeihen, G.D., Hodges, W.C., du Bray, E.A., O’Neill, J.M., 2002, SHRIMP $\mathrm{U}-\mathrm{Pb}$ and ${ }^{40} \mathrm{Ar} /{ }^{39} \mathrm{Ar}$ age constraints for relating plutonism and mineralization in the Boulder Batolith region, Montana: Economic Geology, 97, 241-267.
Lyakhovich, V.V., 1973, Rare elements in the accessory minerals of the granitoids: Nedra, Moscow, 309 p.

Lynch, D.J., 1981, Genesis and geochronology of alkaline volcanism in the Pinacate volcanic field, northwestern Sonora, México: Tucson, University of Arizona, Ph.D. Thesis, $250 \mathrm{p}$.

Lynch, D.J., Musselman, T.E., Gutmann, J.T., Patchett, P.J., 1993, Isotopic evidence for the origin of Cenozoic volcanic rocks in the Pinacate volcanic field, northwestern Mexico: Lithos, 29, 295-302.

Maas, R., Kinny, P.D., Williams, I.S., Froude, D.O., Compston, W., 1992, The Earth's oldest known crust: A geochronological and geochemical study of $3900-4200$ Ma old detrital zircons from Mt. Narryer and Jack Hills, Western Australia: Geochimica et Cosmochimica Acta, $56,1281-1300$

Marton, G., Buffler, R.T., 1994, Jurassic reconstruction of the Gulf of Mexico basin: International Geology Review, 36, 545-586.

McKee, W.J., Jones, W.N., Anderson, H.T., 1988, Las Delicias Basin, a record of Late Paleozoic arc volcanism in northeastern Mexico: Geology, 16, 37-40.

Miller, C.F., Wooden, J.L., Gerber, M.E., 1992, Plutonism at a tectonically evolving continent margin, Mesozoic granitoids of the eastern Mojave Desert, California, USA (Abstracts), in $29^{\text {th }}$ International Geological Congress: 29, 519.

Miller, J.S., Glazner, A.F., Walker, J.D., Martin, M.W., 1995, Geochronologic and isotopic evidence for Triassic-Jurassic emplacement of the eugeoclinal allochton in the Mojave Desert region, California: Geological Society of America Bulletin, 107, 1441-1457.

Möller, A., O'Brien, P.J., Kennedy, A., Kröner, A., 2003, Linking growth episodes of zircon and metamorphic textures to zircon chemistry: an example from the ultra high temperature granulites of Rogaland (SW Norway), in Vance, D., Müller, W., Villa, I.M. (eds.), Geochronology: Linking the Isotopic Record with Petrology and Textures: Geological Society of London Special Publication 220, 65-81.

Muir, R.J., Ireland, T.R., Weaver, S.D., Bradshaw, J.D., 1996, Ion microprobe dating of Paleozoic granitoids: Devonian magmatism in New Zealand and correlations with Australia and Antartica: Chemical Geology, 127, 191-210

Nourse, J.A., Premo, W.R., Iriondo, A., Stahl, E.R., 2005, Contrasting Proterozoic basement complexes near the truncated margin of Laurentia, northwestern Sonora-Arizona international border region, in Anderson, T.H., Nourse, J.A., McKee, J.W., Steiner, M.B. (eds.), The Mojave-Sonora megashear hypothesis: Development, assessment, and alternatives: Geological Society of America Special Paper 393, 123-182.

Ortega-Gutiérrez, F., Ruiz, J., Centeno-García, E., 1995, Oaxaquia, a Proterozoic microcontinent accreted to North America during the late Paleozoic: Geology, 23, 1127-1130.

Ortega-Obregón, C., Solari, L., Gómez-Tuena, A., Elías-Herrera, M., Ortega-Gutiérrez, F., Macías-Romo, C., 2013, PermianCarboniferous arc magmatism in southern Mexico: U-Pb dating, trace element and $\mathrm{Hf}$ isotopic evidence on zircons of earliest subduction beneath the western margin of Gondwana: International Journal of Earth Sciences, 103(5), 1287-1300.

Pidgeon, R.T., Macambria, M.J.B., Lafon, J.M., 2000, Th-U-Pb isotopic systems and internal structures of complex zircons from an enderbite from the Pium Complex, Carajas province, Brazil: Evidence for the ages of granulite facies metamorphism and the protolith of the enderbite: Chemical Geology, 166, 159-171.

Pindell, J.L., 1985, Alleghanian reconstruction and subsequent evolution of the Gulf of Mexico, Bahamas, and Proto-Caribbean: Tectonics, 4, 1-39.

Pindell, J.L., Dewey, J., 1982, Permo-Triassic reconstruction of western Pangea and the evolution of the Gulf of Mexico/Caribbean region: Tectonics, 1, 179-212.

Poole, F.G., Perry, W.J., Jr., Madrid, R.J., Amaya-Martínez, R., 2005, Tectonic synthesis of the Ouachita-Marathon-Sonora orogenic margin of southern Laurentia: Stratigraphic and structural implications for timing of deformational events and plate tectonic model, in Anderson, T.H., Nourse, J.A., McKee, J.W., Steiner, M.B. (eds.), The Mojave-Sonora megashear hypothesis: Development, 
assessment, and alternatives: Geological Society of America Special Paper 393, 543-596.

Ramos, V.A., Folguera, A., 2008, Andean flat-slab subduction through time, in Murphy, J.B., Keppie, J.D., Hynes, A.J. (eds.), Ancient Orogens and Modern Analogues: Geological Society of London Special Publication 327, 31-54.

Ratschbacher, L., Franz, L., Min, M., Bachmann, R., Martens, U., Stanek, K., Stübner, K., Nelson, B.K., Herrmann, U., Weber, B., LópezMartínez, M., Jonckheere, R., Sperner, B., Tichomirowa, M., Mcwilliams, M.O., Gordon, M., Meschede, M., Bock, P., 2009, The North American-Caribbean plate boundary in Mexico-GuatemalaHonduras, in James, K.H., Lorente, M.A., Pindell, J.L. (eds.), "The Origin and Evolution of the Caribbean Plate": Geological Society of London, 219-293.

Restrepo, J., Toussaint, J., González, H., Linares, E., 1978, Datación de metasedimentos del grupo Ayura-Montebello: Medellín, Universidad Nacional de Colombia, Publicación Especial Geology, 10, 1-5.

Restrepo, J., Toussaint, J., González, H., Cordani, U., Kawashita, K., Linares, E., Parila, C., 1991, Precisiones geocronológicas sobre el occidente colombiano, en Simposio sobre magmatismo andino y su marco tectónico, Volumen 1, Manizales, Colombia, 1-22.

Riggs, N.R., Ash, S.R., Barth, A.P., Gehrels, G.E., Wooden, J.L., 2003, Isotopic age of the Black Forest Bed, Petrified Forest Member, Chinle Formation, Arizona: An example of dating a continental sandstone: Geological Society of America Bulletin, 115, 1315-1323.

Roldán-Quintana, J., McDowell, F.W., Delgado-Granados, H., ValenciaMoreno, M., 2009, East-west variations in age, chemical and isotopic composition of the Laramide batholith in southern Sonora, Mexico: Revista Mexicana de Ciencias Geológicas, 26, 543-563.

Ross, C.A., 1979, Late Paleozoic collision of North and South America: Geology, 7, 41-44.

Ross, C.A., 1986, Paleozoic evolution of southern margin of Permian basin: Geological Society of America Bulletin, 97, 536-554.

Rubatto, D., 2002, Zircon trace element geochemistry: partitioning with garnet and the link between $\mathrm{U}-\mathrm{Pb}$ ages and metamorphism: Chemical Geology, 184, 123-138.

Saleeby, J.B., Busby-Spera, C.J., 1992, Early Mesozoic tectonic evolution of the western U.S. Cordillera, in Burchfiel, B.C., Lipman, P.W., Zoback, M.L. (eds.), The Cordilleran orogen: Boulder, Colorado, conterminous, U.S. Geology of North America, Geological Society of America, G-3, 107-168.

Salvador, A., 1991, Origin and development of the Gulf of Mexico basin, in Salvador, A. (ed.), The Gulf of Mexico basin: Boulder, Colorado, Geological Society of America, Geology of North America, J, 389-444.

Schaaf, P., Weber, B., Weis, P., Groß, A., Ortega-Gutiérrez, F., Kohler, H., 2002, The Chiapas massif (Mexico) revised: New geologic and isotopic data and basement characteristics: Neues Jahrbuch für Geologie und Paläontologie - Abhandlungen, 225(1), 1-23.

Schweickert, R.A., Lahren, M.M., 1993, Triassic-Jurassic magmatic arc in eastern California and western Nevada: Arc evolution, cryptic tectonic breaks, and significance of the Mojave-Snow Lake fault, in Dunne, G.C., McDougall, K.A. (eds.), Mesozoic Paleogeography of the western United States, Volume II: Los Angeles, Pacific Section, Society of Economic Paleontologists and Mineralogists (Society for Sedimentary Geology), Book 71, 653-676.

Sedlock, R.L., Ortega-Gutiérrez, F., Speed, R.C., 1993, Tectonostratigraphic terranes and tectonic evolution of Mexico: Geological Society of America Special Paper 278, 153 p.

Servicio Geológico Mexicano (SGM), 2002, Carta Geológico-Minera Puerto Peñasco H12-1, Sonora, escala 1:250000.

Silver, L.T., Anderson, T.H., 1974, Possible left-lateral early to middle Mesozoic disruption of the southwestern North American Craton margin: Geological Society of America Abstracts with Programs, 6, 955-956.

Singh, S., Barley, M.E., Brown, S.J., Jain, A.K., Manickavasagam, R.M., 2002, SHRIMP U-Pb in zircon geochronology of the Chor granitoid: Evidence for Neoproterozoic magmatism in the Lesser Himalayan granite belt of NW India: Precambrian Research, 118, 285-292.
Snow, J.K., Asmeron, Y., Lux, D.R., 1991, Permian-Triassic plutonism and tectonics, Death Valley region, California and Nevada: Geology, $19,629-632$.

Solari, L.A., Dostal, J., Ortega-Gutiérrez, F., Keppie, J.D., 2001, The 275 Ma arc-related La Carbonera stock in the northern Oaxacan Complex of southern Mexico: U-Pb geochronology and geochemistry: Revista Mexicana de Ciencias Geológicas, 18, 149-161.

Solari, L.A., Ortega-Gutiérrez, F., Elías-Herrera, M., Schaaf, P., Norman, M., Torres De León, R., Ortega-Obregón, C., Chiquin, M., MoránIcal, S., 2009, U-Pb zircon geochronology of Paleozoic units in Western and Central Guatemala: insights into the tectonic evolution of Middle America, in James, K., Lorente, M.A., Pindell, J. (eds.), Origin and evolution of the Caribbean Plate: Geological Society of London, 328 (Special Publications), 293-311.

Spikings, R., Cochrane, R., Villagomez, D., Van der Lelij, R., Vallejo, C., Winkler, W., Beate, B., 2015, The geological history of northwestern South America: from Pangaea to the early collision of the Caribbean Large Igneous Province (290 - 75 Ma): Gondwana Research, 27, 95-139.

Stewart, J.H., 1976, Late Precambrian margin of North America: Plate tectonic implications: Geology, 4, 11-15.

Stewart, J.H., 1988, Latest Proterozoic and Paleozoic southern margin of North America and the accretion of Mexico: Geology, 16, 186-189.

Stewart, J.H., Anderson, T.H., Haxel, G.B., Silver, L.T., Wrigth, J.E., 1986, Late Triassic paleogeography of the southern Cordillera: The problem of a source for voluminous volcanic detritus in the Chinle Formation of the Colorado Plateau region: Geology, 14, 567-570.

Stewart, J.H., Blodgett, R.B., Boucot, A.J., Carter, J.L., López, R., 1999, Exotic Paleozoic strata of Gondwanan provenance near Ciudad Victoria, Tamaulipas, Mexico, in Ramos, V.A., Keppie, J.D. (eds.), Laurentia-Gondwana connections before Pangea: Geological Society of America Special Paper 336, 227-252.

Thrane, K., 2002, Relationships between Archean and Paleoproterozoic crystalline basement complexes in the southern part of the East Greenland Caledonides: An ion microprobe study: Precambrian Research, 113, 19-42.

Torres, R., Ruiz, J., Patchett, P.J., Grajales, J.M., 1999, Permo-Triassic continental arc in eastern México: Tectonic implications for reconstructions of southern North America, in Bartolini, C., Wilson, J.L., Lawton, T.F. (eds.), Mesozoic Sedimentary and Tectonic History of North-Central Mexico: Geological Society of America Special Paper 340, 191-196.

Valencia-Moreno, M., Ruiz, J., Barton, M.D., Patchett, P.J., Zurcher, L., Hodkinson, D.G., Roldán-Quintana, J., 2011, A chemical and isotopic study of the Laramide granitic belt of Northwestern Mexico: Identification of the southern edge of the North American Precambrian basement: Geological Society of America Bulletin, 113(11), 1409-1422.

Vavra, G., Schmid, R., Gebauer, D., 1999, Internal morphology, habit and $\mathrm{U}-\mathrm{Th}-\mathrm{Pb}$ microanalysis of amphibolite-to-granulite facies zircons: geochronology of the Ivrea Zone (Southern Alps): Contributions to Mineralogy and Petrology, 134, 380-404.

Velázquez-Santelíz, A.F., 2014, Efecto del basamento proterozoico sobre el magmatismo de arco cordillerano del SW de Norte América: Estudios en Sierra San Francisco, NW de Sonora: Nuevo León, México, Universidad Autónoma de Nuevo León, Facultad de Ciencias de la Tierra, Linares, Tesis de Licenciatura 153 p.

Vidal-Solano, J.R., Demant, A., Paz-Moreno, F.A., Lapierre, H., OrtegaRivera, M.A., Lee, J.K.W., 2008, Insights into the tectonomagmatic evolution of NW Mexico: Geochronology and geochemistry of the Miocene volcanic rocks from the Pinacate area, Sonora: Geological Society of America Bulletin, 120, 691-708.

Viele, G.W., Thomas, W.A., 1989, Tectonic synthesis of the Ouachita orogenic belt, in Hatcher, R.D., Jr., Thomas, W.A., Viele, G.W. (eds.), The Appalachian-Ouachita orogenic belt in the United States: Boulder, Colorado, Geological Society of America, Geology of North America, F-2, 695-728.

Vinasco, C.J., Cordani, U.G., González, H., Weber, M., Pelaez, C., 2006, Geochronological, isotopic, and geochemical data from Permo- 
Triassic granitic gneisses and granitoids of the Colombian Central Andes: Journal of South American Earth Sciences, 21, 355-371.

Wang, X., Griffin, W.L., Chen, J., Huang, P., Li, X., 2011, U and Th contents and $\mathrm{Th} / \mathrm{U}$ ratios of zircon in felsic and mafic magmatic rocks: Improved zircon-melt distribution coefficients: Acta Geologica Sinica, 85(1), 164-174.

Weber, B., Cameron, K.L., Osorio, M., Schaaf, P., 2005, A late Permian tectonothermal event affected former Grenville crust in the southern Maya terrane: $\mathrm{U}-\mathrm{Pb}$ zircon ages from the Chiapas massif, SE Mexico: International Geology Review, 47, 509-529.

Weber, B., Iriondo, A., Premo, W.R., Hecht, L., Schaaf, P., 2007, New insights into the history and origin of the southern Maya block, SE Mexico: U-Pb-SHRIMP zircon geochronology from metamorphic rocks of the Chiapas massif: International Journal of Earth Sciences, 96, 253-269.

Wilde, S.A., Youssef, K., 2000, Significance of SHRIMP U-Pb dating of the Imperial Porphyry and associated Dokhan Volcanics, Gebel Dokhan, north Eastern Desert, Egypt: Journal of African Earth Sciences, 31, 403-413.

Wilde, S.A., Valley, J.W., Peck, W.H., Graham, C.M., 2001, Evidence from detrital zircons for the existence of continental crust and oceans on the Earth 4.4 Gyr ago: Nature, 409, 175-178.

Williams, I.S., Claesson, S., 1987, Isotopic evidence for the Precambrian provenance and Caledonian metamorphism of high grade paragneisses from the Seve Nappes, Scandinavian Caledonides: Contributions to Mineralogy and Petrology, 97, 205-217.

Wooden, J.L., Miller, D.M., 1990, Chronologic and isotopic framework for Early Proterozoic crustal evolution in the eastern Mojave Desert region, southeastern California: Journal of Geophysical Research, 95, 20,133-20,146

Young, D.N., Fanning, C.M., Shaw, R.D., Edgoose, C.J., Blake, D.H., Page, R.W., Camacho, A., 1995, U-Pb zircon dating of tectonomagmatic events in the northern Arunta Inlier, central Australia: Precambrian Research, 71, 45-68.

Zhai, M., Ni, Z., OH, C., Guo, J., Choi, S., 2005, SHRIMP zircon age of a Proterozoic rapavaki granite batholite in the Gyeonggi massif (South Korea) and its geological implications: Geological Magazine, 142, 23-30.

Zheng, Y.F., Fu, B., Li, Y., 1999, Hydrogen and oxygen isotope evidence for fluid-rock interactions in the stages of pre-and post-UHP metamorphism in the Dabie Mountains: Science in China, Ser. D (in Chinese), 29(2), 113

Zhou, M., Yan, D., Kennedy, A.K., Li, Y., Ding, J., 2002, SHRIMP U-Pb geochronology and geochemical evidence for Neoproterozoic arcmagmatism along the western margin of the Yangtze Block, South China: Earth and Planetary Science Letters, 196, 51-67. 


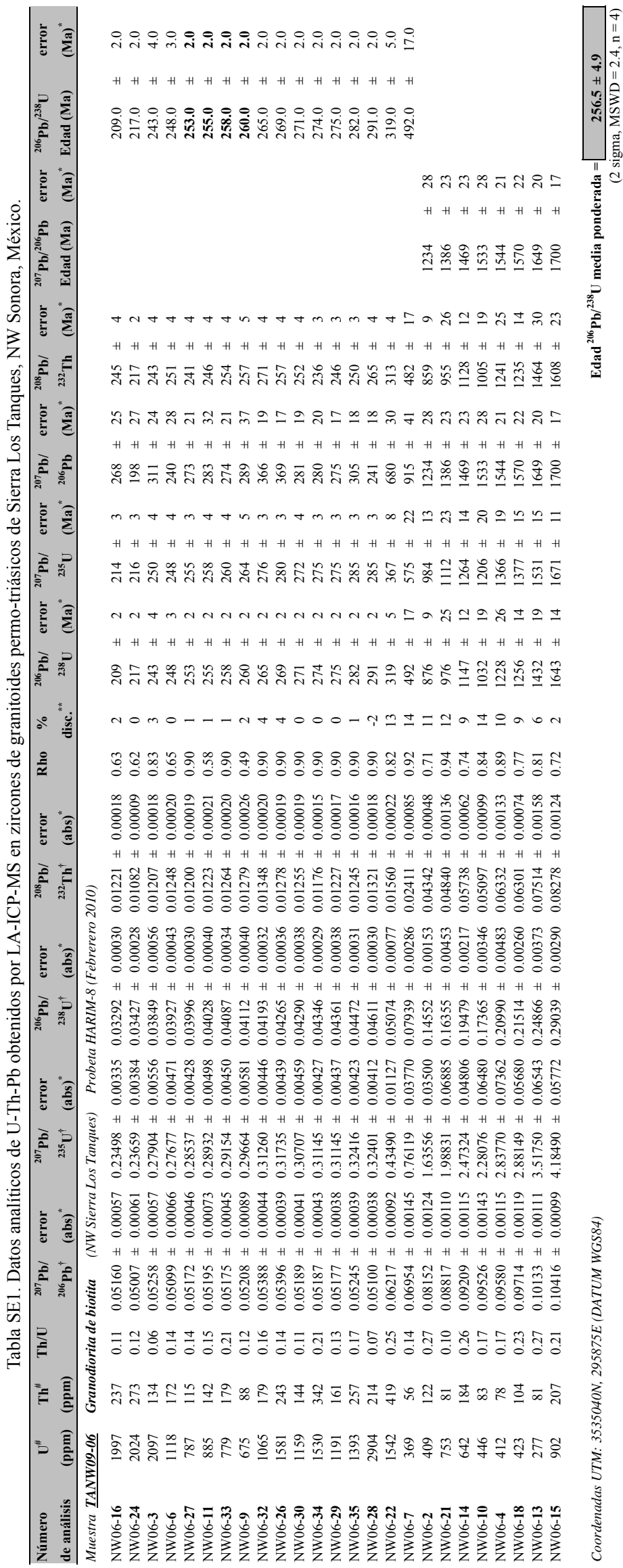

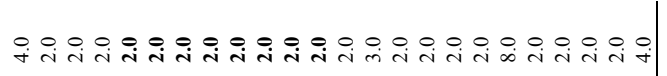

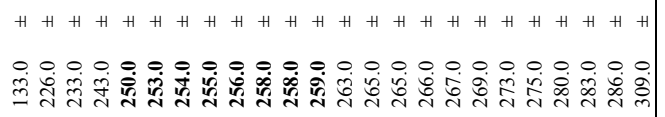
tmmnm+n H H H H H H H H H H H H H H H H H H H H H H H H

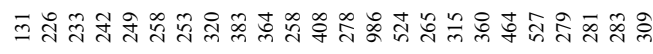

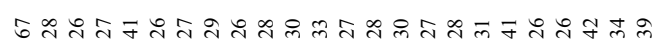
H H H H H H H H H H H H H H H H H H H H H H H H

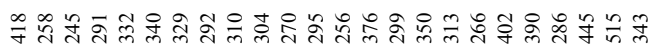

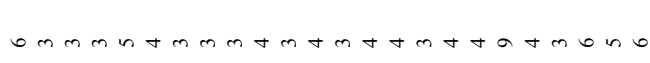
H H H H H H H H H H H H H H H H H H H H H H H H

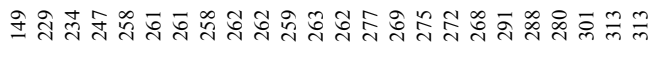

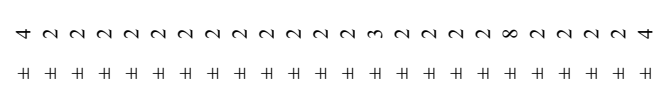

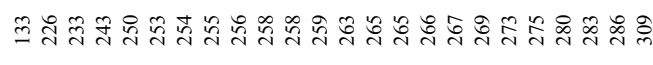

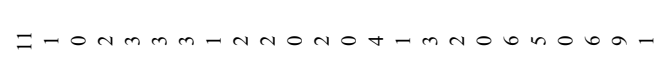

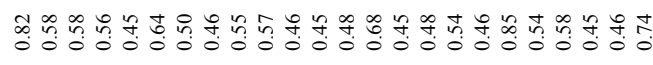

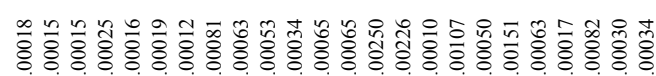
0
0
1

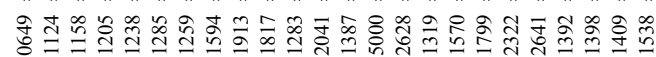

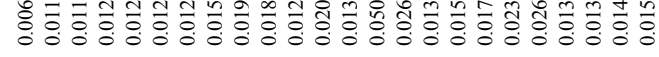

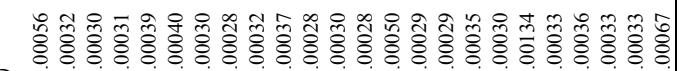
告

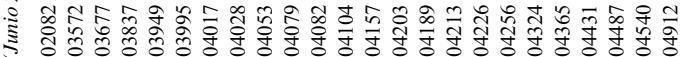

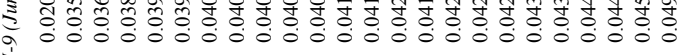

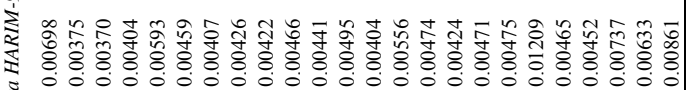

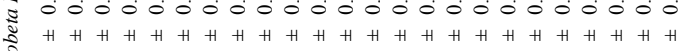

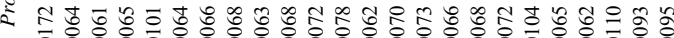
џ 急 告 西H H H H H H H H H H H H H H H H H H H H H H H H

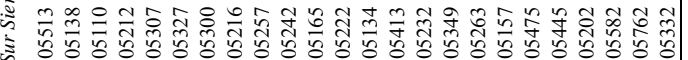

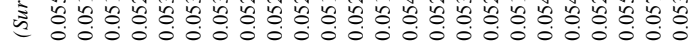

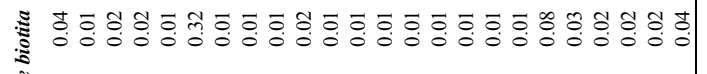
के

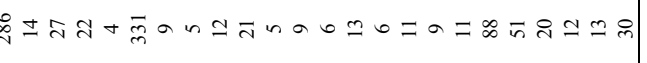

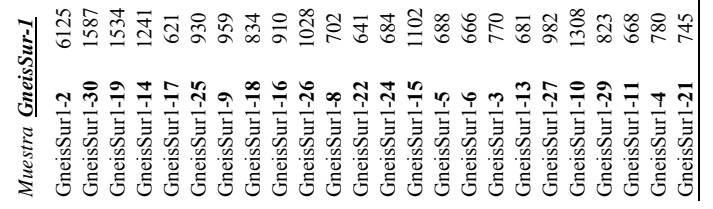




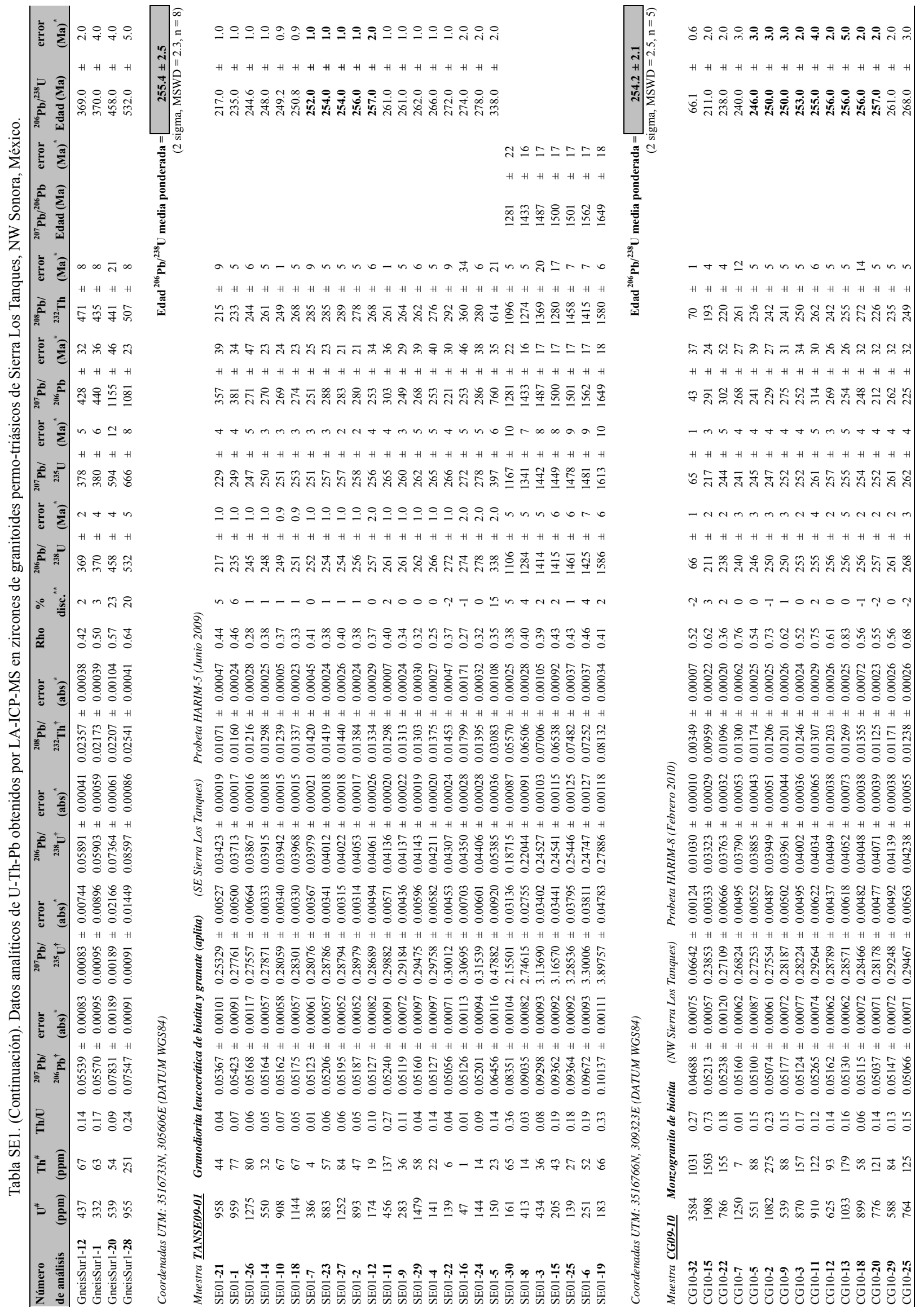




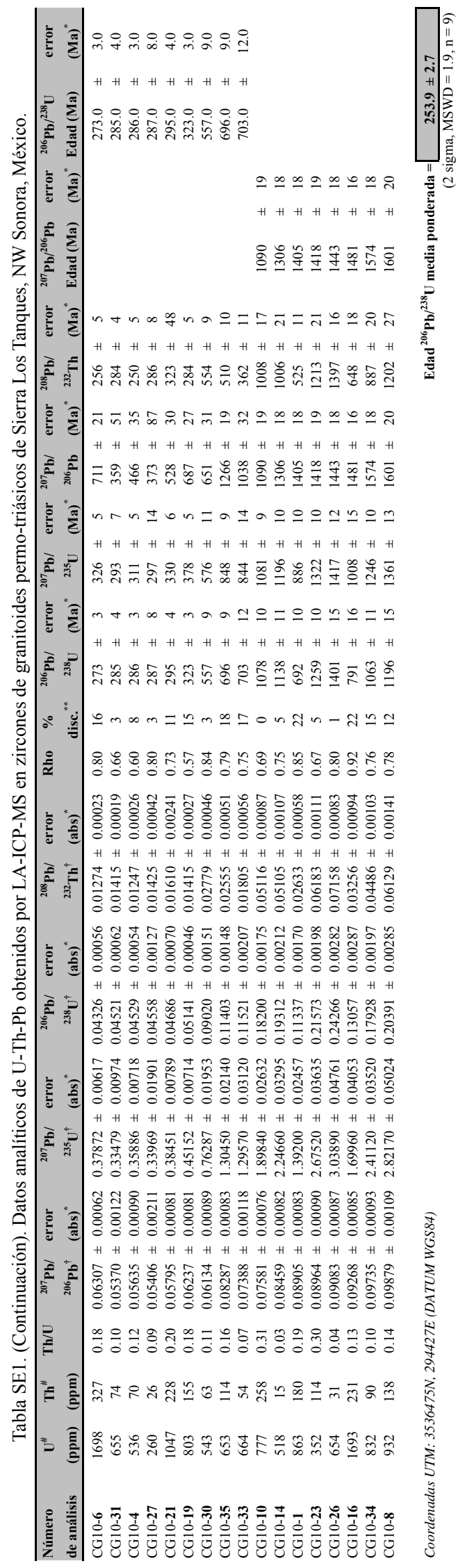

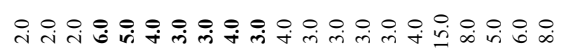

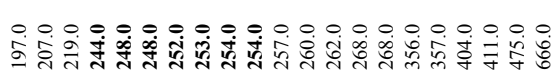

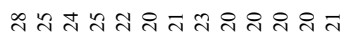

H H H H H H H H H H H H H

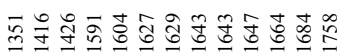

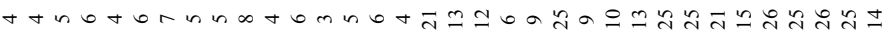

H H H H H H H H H H H H H H H H H H H H H H H H H H H H H H H H H H

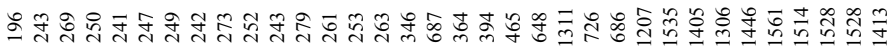

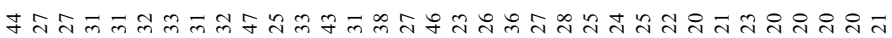
H H H H H H H H H H H H H H H H H H H H H H H H H H H H H H H H H H

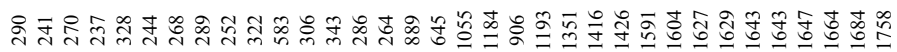

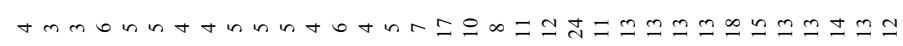
H H H H H H H H H H H H H H H H H H H H H H H H H H H H H H H H H H

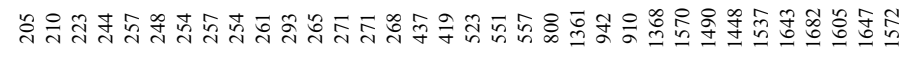

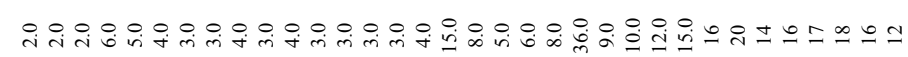
H H H H H H H H H H H H H H H H H H H H H H H H H H H H H H H H H H

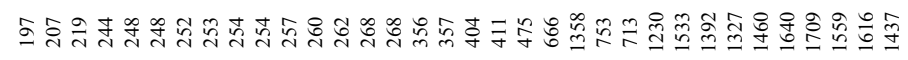

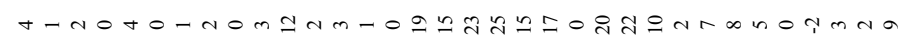

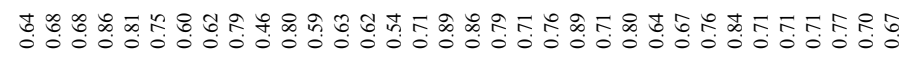

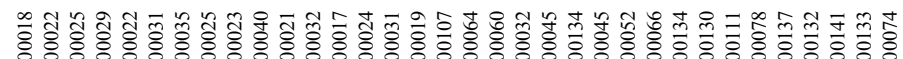

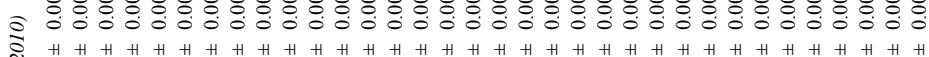

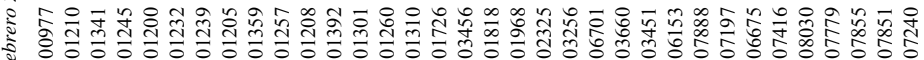
选 夜 I

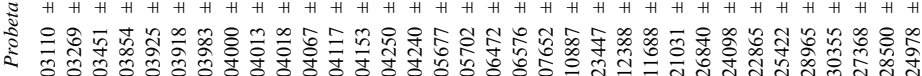

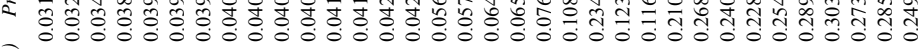

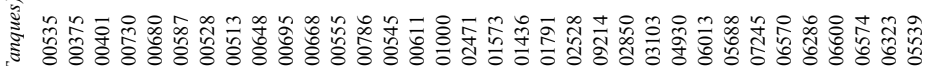
宓 号 H H H H H H H H H H H H H H H H H H H H H H H H H H H H H H H H H H

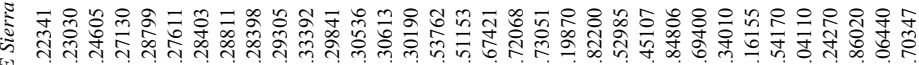
出 đู่

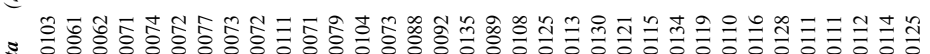

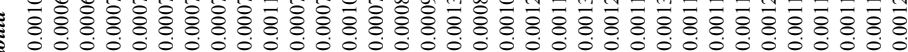
8

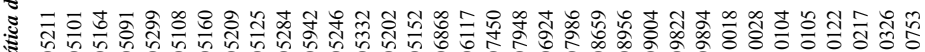

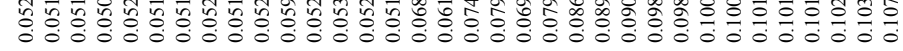

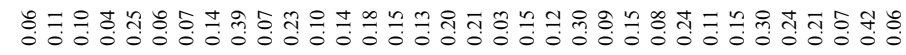

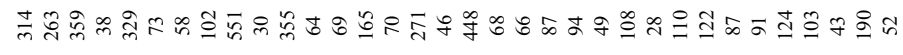

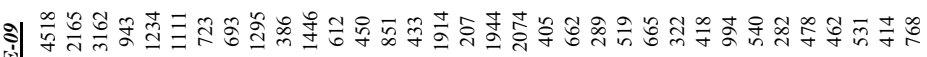
究

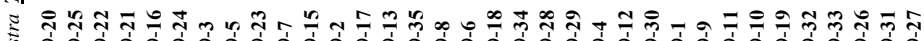

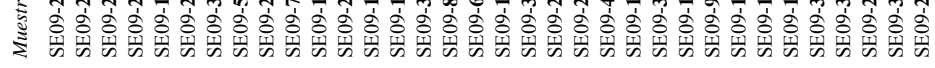



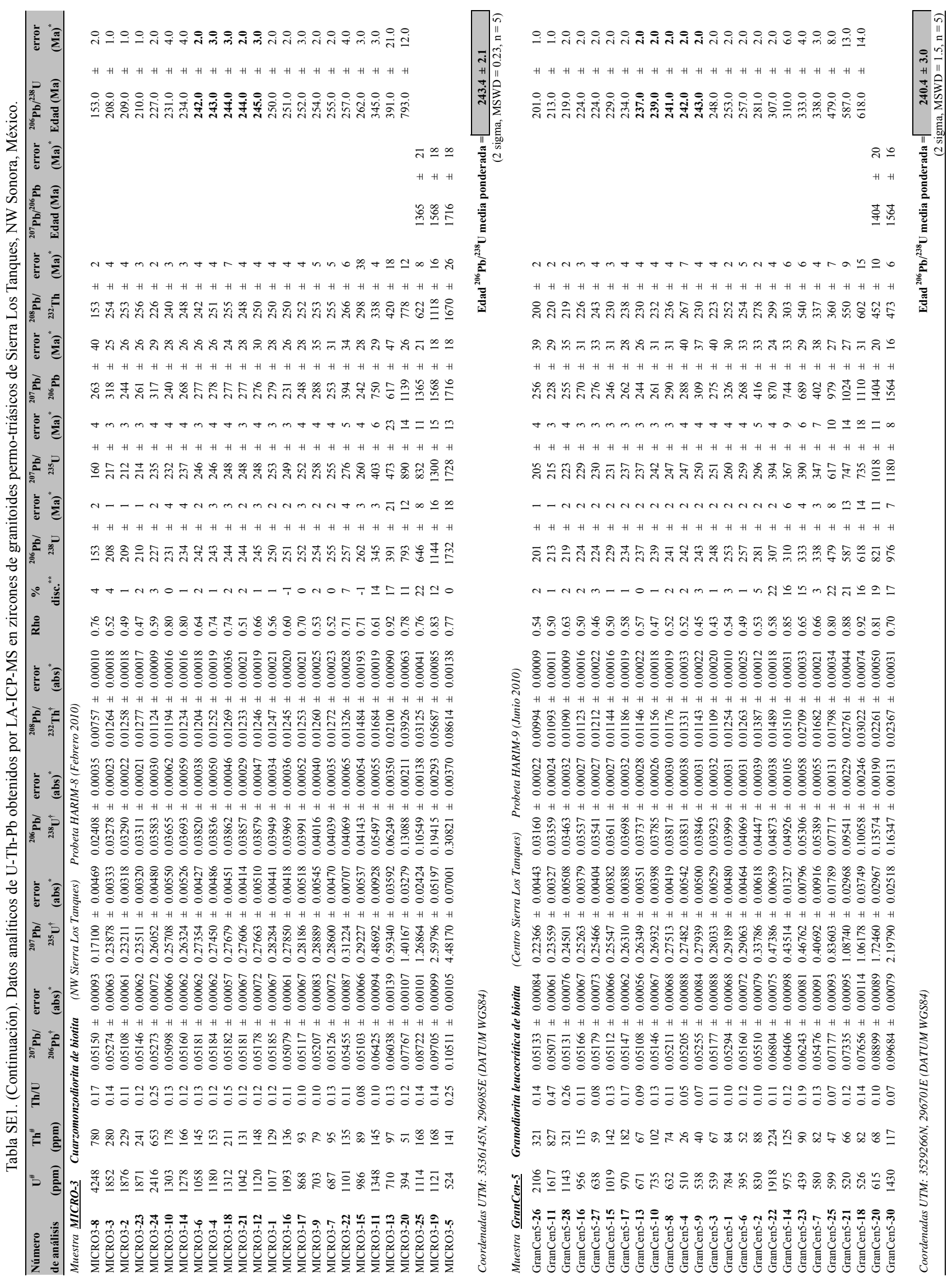


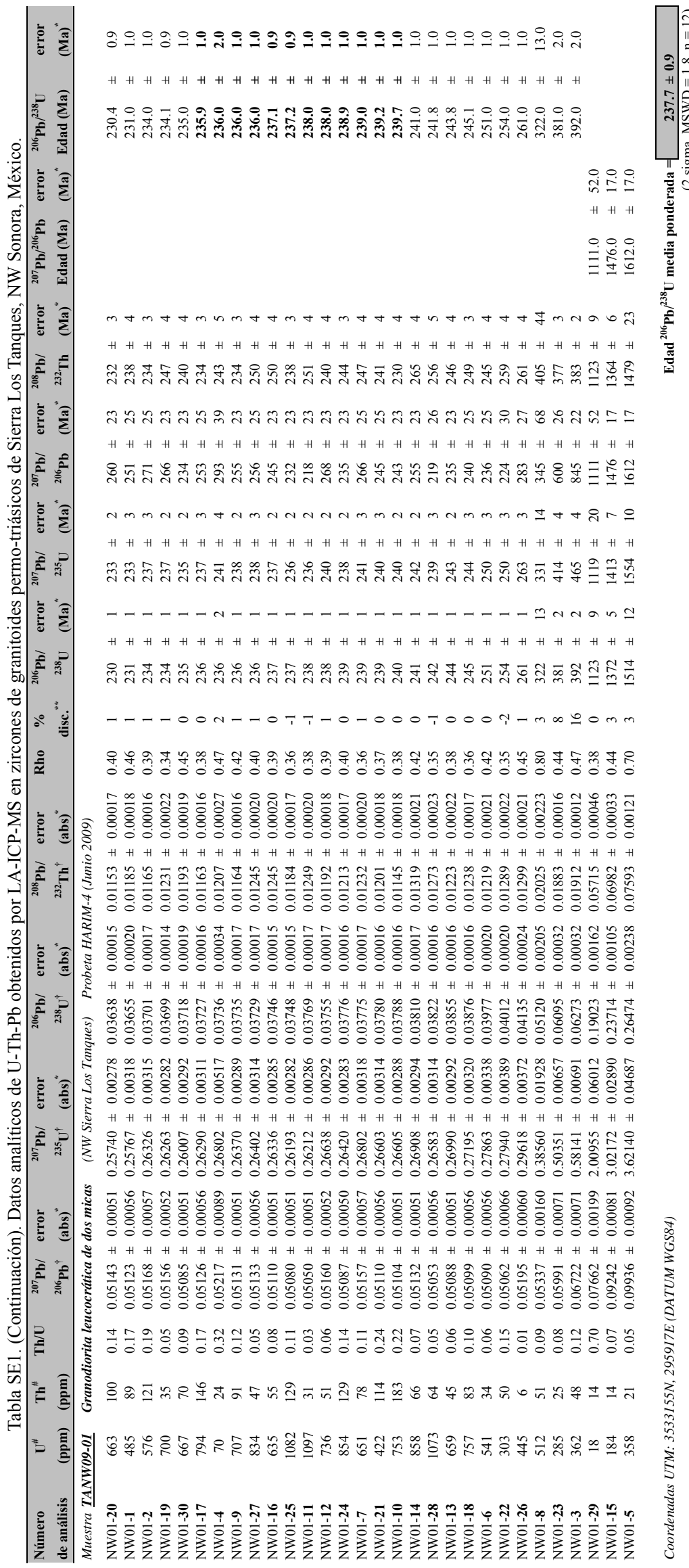

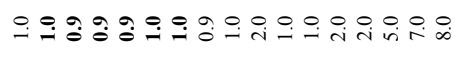
H H H H H H H H H H H H H H H H H

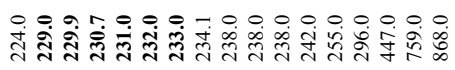

조은 H H H H H

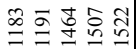

H H H H H H H H H H H H H H H H H H H H H H

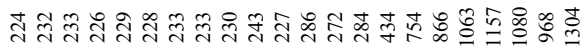

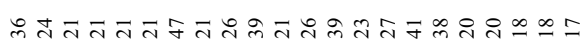

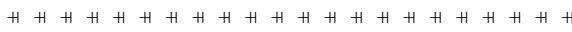

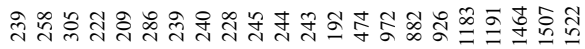
H H H H H H H H H H H H H H H H H H H H H H

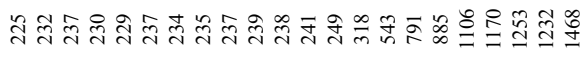

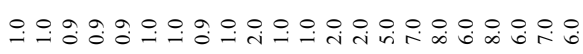
H H H H H H H H H H H H H H H H H H H H H H

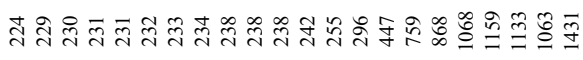
o-motho00000hn thm-正m

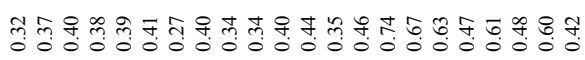

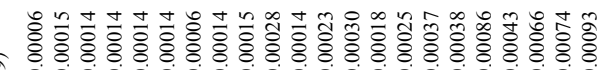
ब, N H H H H H H H H H H H H H H H H H H H

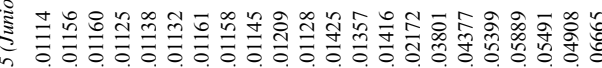

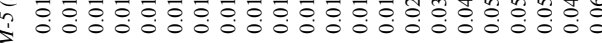
䍃

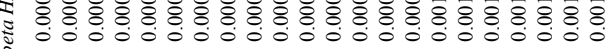
年

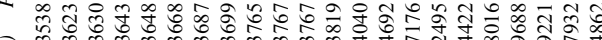

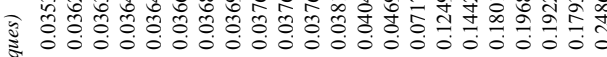

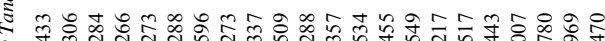

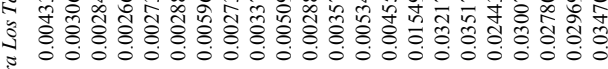
要 H H H H H H H H H H H H H H H H H H H H H H H

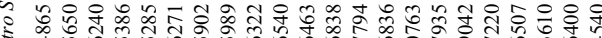

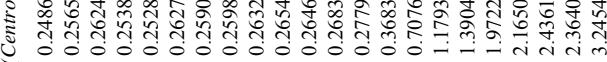

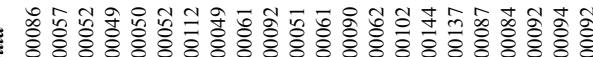
-

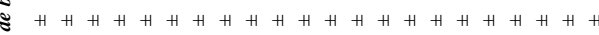

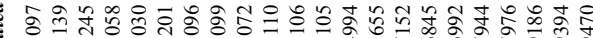

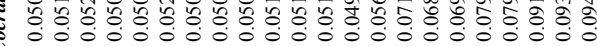

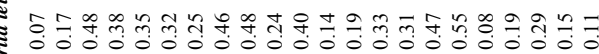

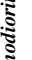

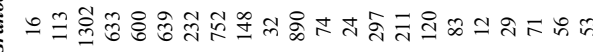

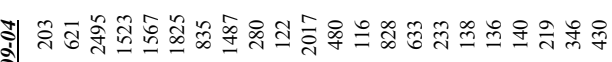
ไู่

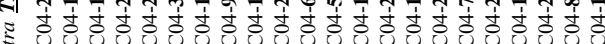

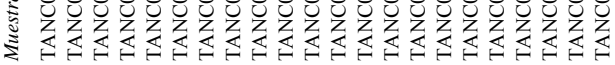




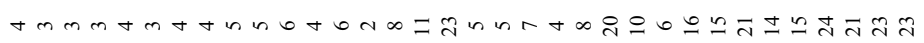

H H H H H H H H H H H H H H H H H H H H H H H H H H H H H H H H H H

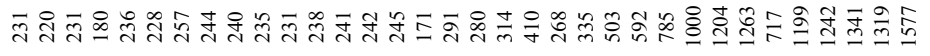

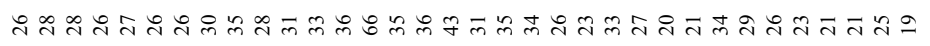
H H H H H H H H H H H H H H H H H H H H H H H H H H H H H H H H H H

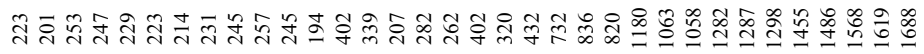

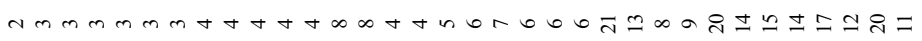
H H H H H H H H H H H H H H H H H H H H H H H H H H H H H H H H H H

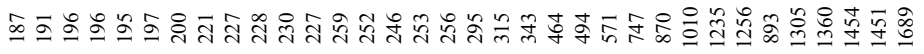

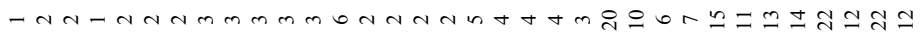
H H H H H H H H H H H H H H H H H H H H H H H H H H H H H H H H H H

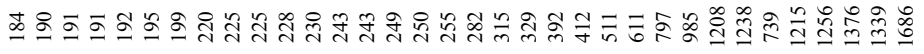

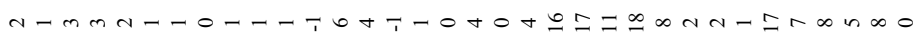

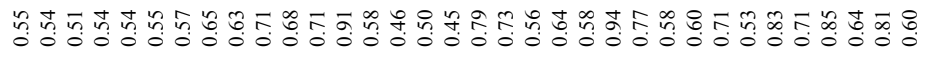

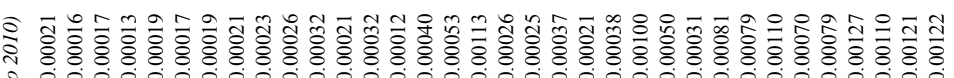
000000

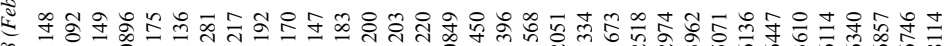
急

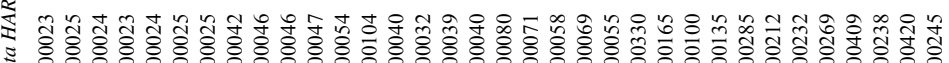
要

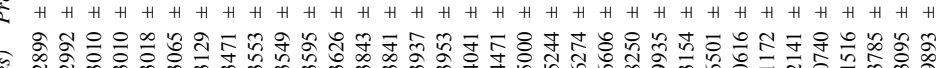

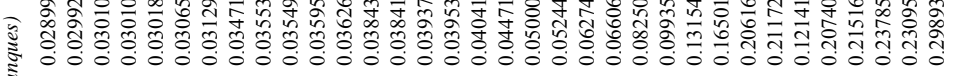

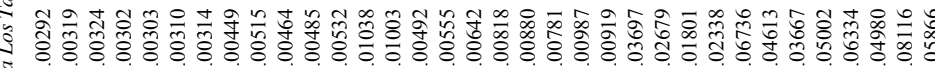
造 000 H

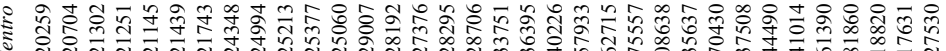

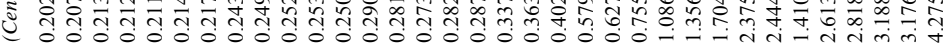
‡

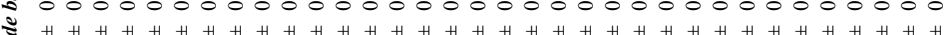

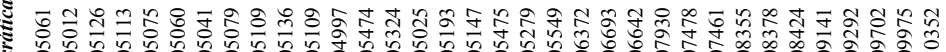

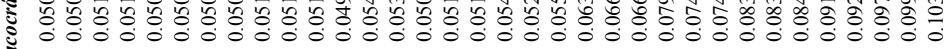
帘

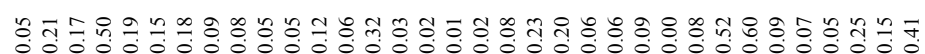

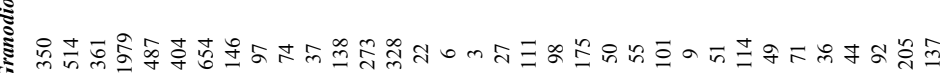

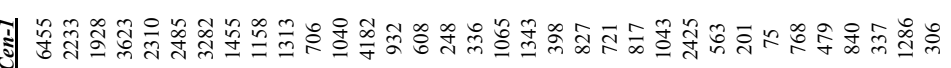

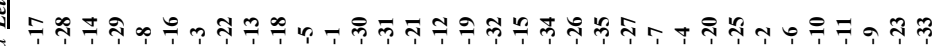

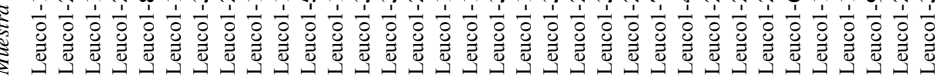

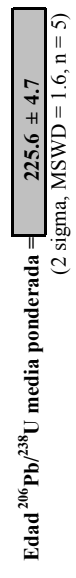

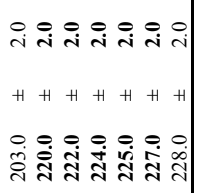

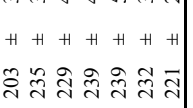
的亦 H H H H H H H H

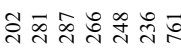
ommanas H H H + + + + H + H

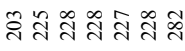

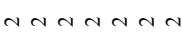
H H H H H H H

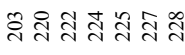
onma-os

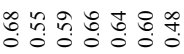

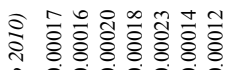
宅 000000 के 랄 息

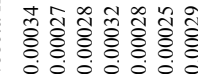
H H H H H H H H

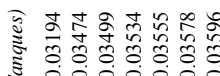

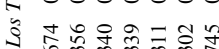
罂

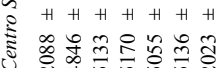

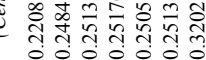

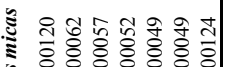

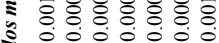

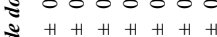

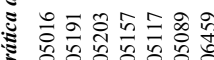
동

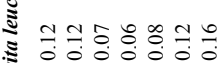

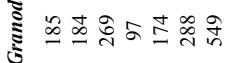

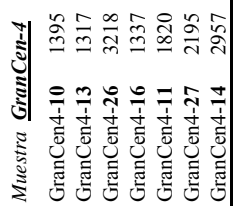



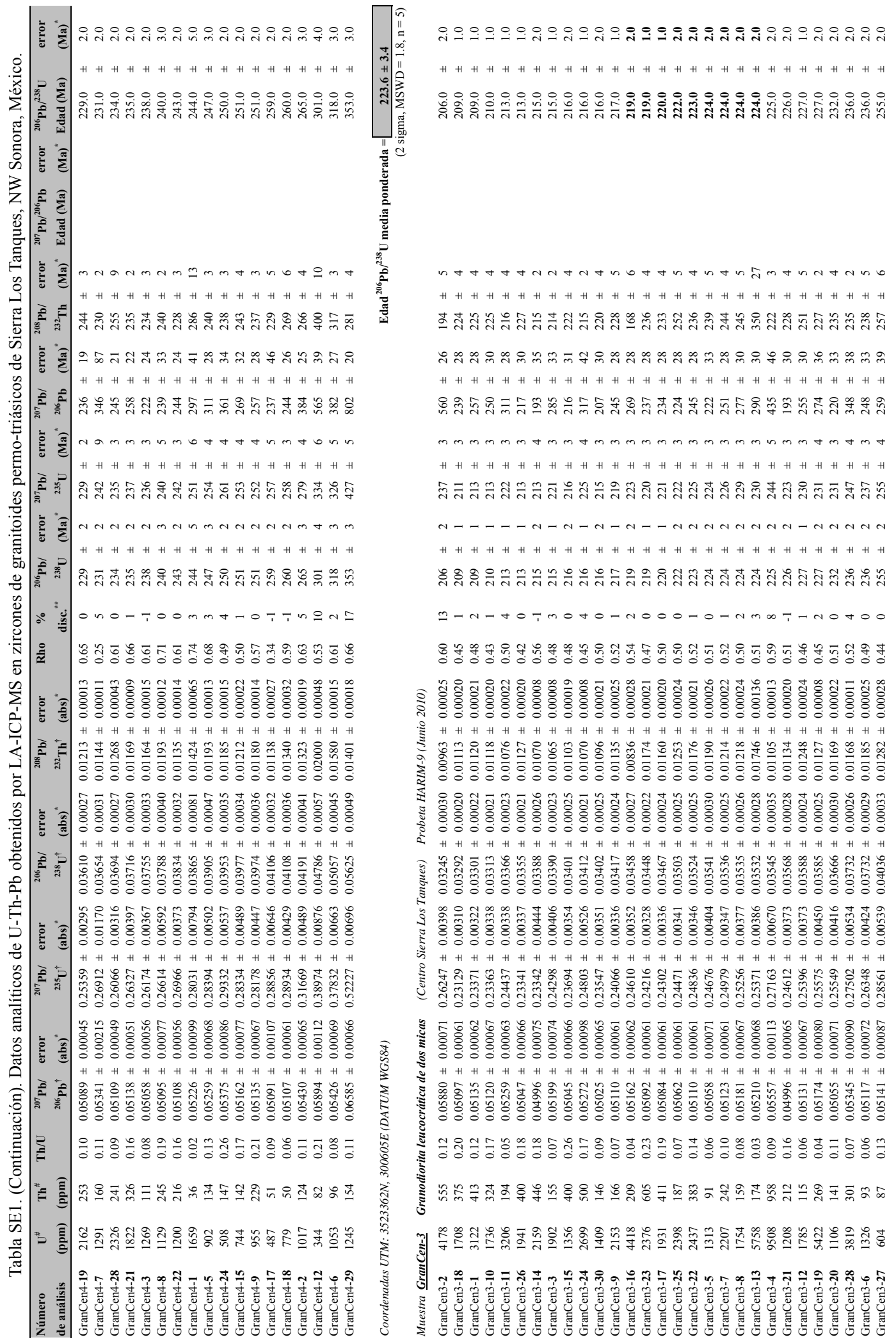
Anexo. Suplemento electrónico. Técnicas analíticas.

\section{Muestreo y preparación para análisis geocronológicos}

Con base en el estudio cartográfico realizado para reconocer las diferentes unidades geológicas, se realizó un extenso muestreo de las rocas representativas de la Sierra Los Tanques para llevar a cabo estudios geocronológicos. Las muestras se procesaron en los laboratorios del Centro de Geociencias (CGEO), UNAM, Campus Juriquilla, Querétaro (Taller de Molienda, Laboratorio de Separación de Minerales, etc.).

\section{Preparación y caracterización de zircones para análisis geocronológicos $\mathrm{U}-\mathrm{Pb}$}

Los zircones fueron obtenidos de muestra de roca pulverizada usando una combinación de técnicas convencionales de separación magnética y líquidos pesados empleadas en el Laboratorio de Separación Mineral del Centro de Geociencias, UNAM, Campus Juriquilla, Querétaro. Alrededor de cien granos de zircón de cada muestra fueron seleccionados cuidadosamente bajo un microscopio binocular con la finalidad de asegurarnos que los cristales fueran representativos de varias poblaciones de zircones (tamaño, forma y color) para después ser montados en una resina epóxica y, posteriormente, desbastados hasta exponer una superficie lo más cercana posible a la mitad ecuatorial de los zircones. Antes de los análisis in situ por ablación láser, las superficies pulidas de los granos de zircón fueron fotografiadas en el Denver Microbeam Laboratory del U.S. Geological Survey en Denver, Colorado, usando un microscopio electrónico de barrido (SEM; Scanning Electron Microscope) marca JEOL 5800LV con detector de cátodoluminiscencia (imágenes SEM-CL). También se obtuvieron imágenes de luz reflejada y transmitida utilizando un microscopio óptico convencional marca Olympus en el Centro de Geociencias, UNAM. Las imágenes de cátodoluminiscencia, luz reflejada y transmitida fueron obtenidas con el propósito de caracterizar la estructura interna de los zircones y elegir los sitios potenciales para los análisis de $\mathrm{U}-\mathrm{Pb}$, observando el zoneamiento relacionado a los cambios de composición química de los zircones para poder detectar posibles inclusiones, sobrecrecimientos metamórficos o herencias que cambiarían el sentido de la interpretación de los datos analíticos. Esta es una herramienta ventajosa para interpretar las edades obtenidas.

\section{Geocronología U-Pb en zircones por LA-ICP-MS}

Los análisis isotópicos de $\mathrm{U}-\mathrm{Pb}$ en zircones fueron realizados en el Laboratorio de Estudios Isotópicos (LEI) en el Centro de Geociencias (CGEO), UNAM, Campus
Juriquilla, Querétaro, utilizando la técnica de ablación láser (LA-ICP-MS). En la actualidad, está técnica de microanálisis y fechamiento es ventajosa ya que permite hacer mediciones isotópicas de alta precisión y rapidez para obtener edades y concentraciones geoquímicas en materiales geológicos.

El LEI cuenta con un sistema de ablación láser modelo Resolution M50 de la marca "Resonetics" compuesto por un láser LPX 220 tipo excímero de $193 \mathrm{~nm}$ de longitud de onda utilizando una mezcla de fluoruro de argón (ArF) para generar la pulsación. Este se encuentra acoplado a un espectrómetro de masas (ICP-MS) tipo quadrupolo marca "Thermo X-Series". El sistema fue recientemente descrito por Solari et al. (2010), quienes presentaron la metodología para los análisis isotópicos $\mathrm{U}(\mathrm{Th})-\mathrm{Pb}$ en zircones. Sin embargo, a continuación presentamos de manera breve la metodología básica utilizada en el LEI.

Previo a la medición isotópica, las muestras (probeta con zircones) se limpiaron con $\mathrm{HNO}_{3} 1 \mathrm{M}$ con la finalidad de eliminar o minimizar cualquier posible contaminación por la presencia de $\mathrm{Pb}$ común en la superficie de los granos. La ablación láser se realiza en una celda de nueva generación de doble volumen que puede alojar hasta 4 probetas con muestras. Los cristales de zircón fueron ablacionados dentro de esta celda en una atmósfera de $\mathrm{He}$, la cual proporciona una condición óptima para este proceso (Horn y Günther, 2003). Primeramente, el haz del láser incide sobre la superficie del cristal con una energía de $\sim 130-140 \mathrm{~mJ}$ y a una tasa de repetición de $5 \mathrm{~Hz}$ creando un hoyo provocado por la volatilización de un área del zircón (spot o punto de análisis) de $\sim 33 \mu \mathrm{m}$ de diámetro y de $\sim 25 \mu \mathrm{m}$ de profundidad para obtener un total de $\sim 75-85 \mathrm{ng}$ de masa ablacionada durante cada análisis. La ablación se lleva a cabo por alrededor de 30 segundos con el fin de minimizar la profundidad del hoyo de ablación y, de la misma manera, el fraccionamiento elemental. Posteriormente, el material ablacionado (vaporizado) es evacuado de la celda de ablación y transportado al espectrómetro de masas en un flujo de $\mathrm{He}$ y $\mathrm{N}_{2}$ mezclado con gas Ar (flujos de gas optimizados diariamente) para después ser analizado.

En el caso de los análisis en zircones, una secuencia típica de medición por ablación láser en el LEI inicia con el análisis de dos muestras de referencia certificada (vidrios estándar NIST SRM 610), seguido por cinco análisis de material de referencia natural cuya composición y/o edad han sido ya publicadas (zircón estándar Pleŝovice; Sláma et al., 2008) y finalmente cinco zircones de edad desconocida. Posteriormente, se hace una medición de esta muestra natural de zircón estándar Pleŝovice después de cada cinco mediciones en muestras desconocidas. El experimento finaliza con dos zircones estándar y un vidrio NIST. Esta secuencia es de gran importancia y conocida como un método estándar para poder realizar la corrección 
por fraccionamiento de masa y deriva instrumental (e.g., Jackson et al., 1992, 1996; Gehrels et al., 2008; Solari et al., 2010). Los análisis del vidrio NIST son utilizados para calcular las concentraciones correctas de U y Th, además de las otras concentraciones de elementos traza y tierras raras medidas durante cada análisis, mientras que los análisis del estándar de zircón Pleŝovice son usados para recalcular las relaciones isotópicas.

La calibración de los datos y correcciones por deriva instrumental (drift) fueron basadas en los estándares de zircón Pleŝovice obtenidos de una granulita potásica que tiene una edad ${ }^{206} \mathrm{~Pb} /{ }^{238} \mathrm{U}$ concordante con una media ponderada de $337.13 \pm 0.37 \mathrm{Ma}$ obtenida utilizando la técnica de dilución isotópica y espectrometría de masas por ionización térmica (ID-TIMS) (Sláma et al., 2008).

Los datos isotópicos fueron adquiridos utilizando el software analítico Thermo PlasmaLab con resolución temporal, permitiendo que las relaciones isotópicas sean calculadas de los datos adquiridos en un intervalo de tiempo específico.

Durante el análisis de cada zircón los isótopos de interés principal para el fechamiento $\mathrm{U}-\mathrm{Pb}$ como ${ }^{206} \mathrm{~Pb},{ }^{207} \mathrm{~Pb}$, ${ }^{208} \mathrm{~Pb},{ }^{232} \mathrm{Th}$ y ${ }^{238} \mathrm{U}$ fueron determinados, además de otros isótopos importantes como ${ }^{29} \mathrm{Si},{ }^{31} \mathrm{P},{ }^{49} \mathrm{Ti},{ }^{89} \mathrm{Y},{ }^{91} \mathrm{Zr},{ }^{139} \mathrm{La}$, ${ }^{140} \mathrm{Ce},{ }^{147} \mathrm{Sm},{ }^{153} \mathrm{Eu},{ }^{163} \mathrm{Dy},{ }^{175} \mathrm{Lu}$ y ${ }^{177} \mathrm{Hf}$. Por ejemplo, el silicio y el zirconio son usados como elementos estándar internos para la cuantificación del contenido de elementos traza, considerando su concentración estequiométrica en el zircón, mientras que elementos como el $\mathrm{P}$, Ti e Y, además de algunas tierras raras, son monitoreados como indicadores de la presencia de inclusiones dentro de los zircones (p.ej., monazita, apatito o titanita), las cuales podrían modificar las relaciones $\mathrm{U}(\mathrm{Th})-\mathrm{Pb}$ del zircón y proporcionar edades equívocas y mediciones erróneas como en el caso de la presencia de $\mathrm{Pb}$ común.

Debido a que el trabajo analítico requiere de una precisa y sistemática reducción de los datos, cálculo de edades y concentraciones elementales de los zircones analizados, en el LEI (UNAM) se ha desarrollado el software "UPb. age" para facilitar a los usuarios una rápida y transparente reducción de datos para los fechamientos $\mathrm{U}(\mathrm{Th})-\mathrm{Pb}$ por LAICPMS (Solari y Tanner, 2011). "UPb.age" fue escrito en $\mathrm{R}$, un software libre de lenguaje y entorno de programación para análisis estadístico y gráfico. Un sencillo script llamado "file.trans" es distribuido junto con el "UPb.age", el cual convierte los datos producidos de los análisis por ablación láser grabados por el Thermo PlasmaLab (csv, commaseparated-value) a un formato de archivo uniforme que pude leer fácilmente el "UPb.age".

Con una serie de comandos introducidos por el usuario, el "UPb.age" aplica diferentes correcciones y, además, recalcula las relaciones $\mathrm{U}(\mathrm{Th})-\mathrm{Pb}$, errores y coeficientes de correlación. El "UPb.age" realiza automáticamente el proceso de integración de las señales del ICP-MS y su respectiva corrección por blancos. También identifica, mediante regresión matemática, posibles outliers e inclusiones y los presenta para que éstos sean evaluados por el usuario. El software también ofrece la capacidad de corrección por deriva instrumental usando un modelo linear.

Los resultados y datos generados de los análisis isotópicos después de los diferentes pasos realizados en el proceso de reducción utilizando el "UPb.age" son automáticamente guardados como archivos csv (data. csv y results.csv). Estos archivos contienen información importante como, por ejemplo, las relaciones corregidas de ${ }^{207} \mathrm{~Pb} /{ }^{235} \mathrm{U},{ }^{206} \mathrm{~Pb} /{ }^{238} \mathrm{U},{ }^{208} \mathrm{~Pb} /{ }^{232} \mathrm{Th}$ y ${ }^{207} \mathrm{~Pb} /{ }^{206} \mathrm{~Pb}$ con sus respectivos errores estándar reportados a 1 sigma.

Los archivos csv fueron procesados en un programa macro (in house) de Excel desarrollado en el LEI, el cual permite al operador ordenar automáticamente los datos, hacer una corrección por $\mathrm{Pb}$ común y generar una tabla de datos lista para publicar con las relaciones isotópicas y edades; también como recalcular las concentraciones de elementos traza y mayores de los zircones analizados y producir un diagrama de REE normalizado a condrita con los datos obtenidos. Las relaciones isotópicas son corregidas por $\mathrm{Pb}$ común utilizando la metodología algebraica propuesta por Andersen (2002) para recalcular posteriormente las edades obtenidas. Las edades fueron calculadas y graficadas en diagramas de concordia usando el programa computacional Isoplot 3.0 (add in para Excel) (Ludwig, 2003).

\section{Imágenes de Cátodoluminiscencia de zircones}

La caracterización de zircones por técnicas de microscopía de luz transmitida y reflejada, además de Cátodoluminiscencia (Cathodoluminescence; CL), es fundamental para poder diseñar los experimentos de geocronología de U-Pb en zircones utilizando la técnica LAMC-ICPMS (Laser Ablation-Multi-collector-Inductively Coupled Plasma Mass Spectrometry) y/o SHRIMP-RG (Sensitive High Resolution Ion Micro Probe-Reverse Geometry; Micro Sonda Iónica de Alta Resolución Sensible de Geometría Inversa).

$\mathrm{LaCL}$ a partir de zircones montados en probetas de resina epóxy doblemente pulidas nos permite obtener imágenes de zoneamientos minerales del zircón, que en ocasiones, por si solos, proporcionan información fundamental para entender los procesos de formación de los mismos. Por ejemplo, es posible identificar semillas dentro de los granos únicos de zircón, que de forma preliminar se pueden interpretar como herencia de zircones más antiguos en los que se han nucleado nuevas generaciones de zircón. En ocasiones, también se aprecian bandeados de crecimiento característicos de zircones generados a partir de magmas. Por último, también se pueden observar recrecimientos de zircón que pudieran indicar recrecimientos asociados a metamorfismo. En ocasiones, estas relaciones de crecimiento de zircones nos permiten establecer la edad relativa de estos; sin embargo, son necesarios los fechamientos de U-Pb para establecer la 
edad absoluta de los mismos.

La cátodoluminiscencia es una herramienta importante en la geocronología U-Pb en zircones ya que el estudio de estas imágenes ayudan a decidir el lugar en donde se muestreará el zircón (núcleo o periferia, etc.), ya sea por la técnica de ablación láser o por la técnica de microsonda iónica.

En el siguiente apartado de geocronología se muestran imágenes de cátodoluminiscencia de algunos zircones para cada muestra de roca fechada de la Sierra Los Tanques, NW de Sonora, donde se presenta el lugar de ablación y la edad para ese punto en el zircón.

Las imágenes fueron tomadas en el U.S. Geological Survey de Denver, Colorado, utilizando un microscopio electrónico de barrido (SEM) marca JEOL modelo 5600. Estos estudios fueron supervisados por la Dra. Heather Lowers con ayuda de Dr. Daniel Miggins, ambos empleados del U.S. Geological Survey.

\section{Referencias}

Andersen, T., 2002, Correction of common lead in U-Pb analyses that do not report 204Pb: Chemical Geology, 192, 59-79.

Gehrels, G.E., Valencia, V.A., Ruiz, J., 2008, Enhanced precision, accuracy, efficiency, and spatial resolution of U-Pb ages by laser ablationmulticollector-inductively coupled plasma-mass spectrometry: Geochemistry, Geophysics, Geosystems, 9(3), 1-13.
Horn, I., Günther, D., 2003, The influence of ablation carrier gasses Ar, $\mathrm{He}$, and $\mathrm{Ne}$ on the particle size distribution and transport efficiencies of laser ablation-induced aerosols: Implications for LA-ICP-MS: Applied Surface Science, 207, 144-157.

Jackson, S.E., Longerich, H.P., Dunning, R., Fryer, B.J., 1992, The application of laser-ablation microprobe-inductively coupled plasma mass spectrometry LAM-ICP-MS to in situ trace element determinations in minerals: Canadian Mineralogist, 30,1049-1064.

Jackson, S.E., Longerich, H.P., Horn, I., Dunning, R., 1996, The application of laser ablation microprobe (LAM)-ICP-MS to in situ U-Pb zircon geochronology: Journal of Conference Abstracts, 1, 283.

Ludwig, K.R., 2003, ISOPLOT, A geochronological toolkit for Microsoft Excel, Version 3.00: Berkeley Geochronology Center Special Publication 4, $70 \mathrm{p}$.

Sláma, J., Koŝler, J., Condon, D.J., Crowley, J.L., Gerdes, A., Hanchar, J.M., Horstwood, M.S.A., Morris, G.A., Nasdala, L., Norberg, N., Schaltegger, U., Schoene, B., Tubrett, M.N., Whitehouse, M.J., 2008, Pleŝovice zircon - A new natural reference material for U-Pb and Hf isotopic microanalysis: Chemical Geology, 249, 1-35.

Solari, L.A., Tanner, M., 2011, UPb.age, a fast data reduction script for LA-ICP-MS U-Pb geochronology: Revista Mexicana de Ciencias Geológicas, 28(1), 83-91.

Solari, L.A., Gómez-Tuena, A., Bernal, J.P., Pérez-Arvizu, O., Tanner, M., 2010, U-Pb zircon geochronology by an integrated LA-ICPMS microanalytical workstation: achievements in precision and accuracy: Geostandards and Geoanalytical Research, 34(1), 5-18.

Manuscrito recibido: Febrero 7, 2015

Manuscrito corregido recibido: Julio 10, 2015

Manuscrito aceptado: Julio 15, 2015 